Andrews University

Digital Commons @ Andrews University

\title{
A Description and Analysis of the Implementation of a Strategic Leadership Team in the Oerlikon SDA Church
}

Paul N.T. Wright

Andrews University

Follow this and additional works at: https://digitalcommons.andrews.edu/dmin

Part of the Practical Theology Commons

\section{Recommended Citation}

Wright, Paul N.T., "A Description and Analysis of the Implementation of a Strategic Leadership Team in the Oerlikon SDA Church" (2009). Professional Dissertations DMin. 549.

https://dx.doi.org/10.32597/dmin/549

https://digitalcommons.andrews.edu/dmin/549

This Project Report is brought to you for free and open access by the Graduate Research at Digital Commons @ Andrews University. It has been accepted for inclusion in Professional Dissertations DMin by an authorized administrator of Digital Commons @ Andrews University. For more information, please contact repository@andrews.edu. 


\section{ABSTRACT}

\section{A DESCRIPTION AND ANALYSIS OF THE IMPLEMENTATION OF A STRATEGIC LEADERSHIP TEAM IN \\ THE OERLIKON SDA CHURCH}

by

Paul N. T. Wright

Adviser: Bruce L. Bauer 


\title{
ABSTRACT OF GRADUATE STUDENT RESEARCH
}

Dissertation

\author{
Andrews University
}

Seventh-day Adventist Theological Seminary

Title: A DESCRIPTION AND ANALYSIS OF THE IMPLEMENTATION OF A STRATEGIC LEADERSHIP TEAM IN THE OERLIKON SDA CHURCH

Name of researcher: Paul N. T. Wright

Name and degree of faculty adviser: Bruce L. Bauer, D.Miss.

Date completed: February 2009

\section{Problem}

The Oerlikon Seventh-day Adventist (SDA) Church in a suburb of Zurich, Switzerland declined from a total of 204 members in 1975 to 103 members at the end of 2008. This represents a membership loss of nearly fifty percent in thirty years. It is a hypothesis of this paper that a lack of strategic leadership at local church level is one reason for this decline. The task of this paper is to describe and evaluate a Strategic Leadership Team which came into existence in 2006 as a means of promoting growth in that local church.

\section{Methods}

The project begins by establishing a theological basis for the team structure and 
aims to show not only that many biblical leaders worked with teams but also that those leaders thought strategically. This is followed by a description of the process of setting up a Strategic Leadership Team and of the core activities of Strategic Leadership Teams taken from current literature.

The project then describes the manner in which the Strategic Leadership Team of the Oerlikon SDA Church arose and the vision around which the Team united. It also describes its integration into the existing structures of the church.

Finally, the project describes how the Team went on to form and implement its strategy and analyzes its successes and mistakes by comparing them with its vision and goals.

\section{Results}

While the Strategic Leadership did not significantly change the growth pattern of the Oerlikon SDA congregation within the time period under review it was instrumental in promoting a mission mentality within a significant minority of the members of that church. It was also successful in introducing a new structure within the church which it is hoped will be instrumental in reversing the negative growth trend in the future.

\section{Conclusions}

Despite mistakes, the work of the Team shows promise for the future and has provided a model which can be of use to the leadership of other Adventist churches who wish to grow. 


\title{
Andrews University
}

Seventh-day Adventist Theological Seminary

\section{A DESCRIPTION AND ANALYSIS OF THE IMPLEMENTATION OF A STRATEGIC LEADERSHIP TEAM IN THE OERLIKON SDA CHURCH}

\author{
A Dissertation \\ Presented in Partial Fulfillment \\ of the Requirements for the Degree \\ Doctor of Ministry
}

by

Paul N. T. Wright

February 2009 
(C) Copyright by Paul N. T. Wright

All Rights Reserved 


\title{
A DESCRIPTION AND ANALYSIS OF THE IMPLEMENTATTION OF A STRATEGIC LEADERSHIP TEAM IN \\ THE OERLIKON SDA CHURCH
}

\author{
A dissertation \\ Presented in partial fulfillment \\ of the requirements for the degree \\ Doctor of Ministry
}

by

Paul N. T. Wright

APPROVAL BY THE COMMITTEE

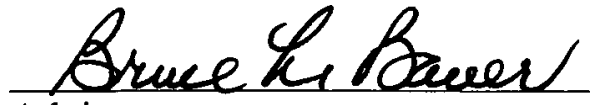

Adviser,

Bruce Bauer
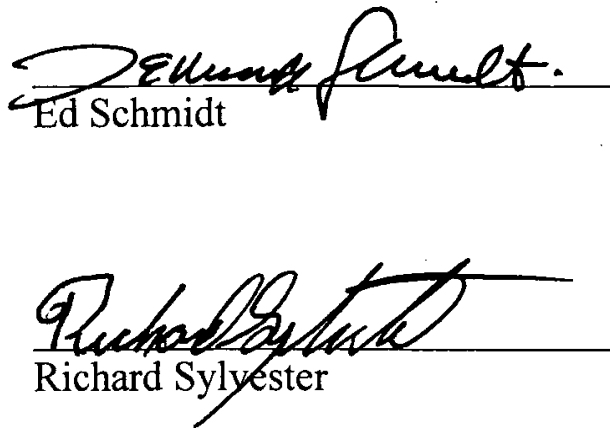

Director of D. Min. Program

Skip Bell

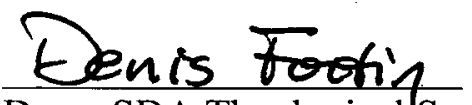

Dean, SDA Theological Seminary

J. H. Denis Fortin

23 March 2009

Date approved 


\section{DEDICATION}

For my Dad, whose vision and encouragement meant that this project was started.

And for Mirjam, whose faithful support and dedicated assistance meant that this project has been completed. 


\section{TABLE OF CONTENTS}

TABLE OF CONTENTS $\ldots \ldots \ldots \ldots \ldots \ldots \ldots \ldots$ iv

LIST OF ILLUSTRATIONS $\ldots \ldots \ldots \ldots \ldots \ldots \ldots \ldots \ldots$

ACKNOWLEDGMENTS ................... xi

Chapter

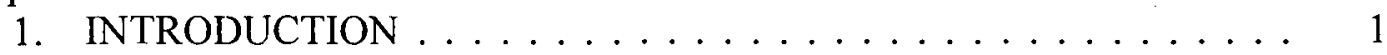

Statement of the Need. . . . . . . . . . . . . . . . 1

Purpose of the Project. . . . . . . . . . . . . . . 3

Definition of Terms . . . . . . . . . . . . . . 4

Strategic Leadership Team. . . . . . . . . . . . . . . 4

Strategic Planning. . . . . . . . . . . . . 5

Leadership . . . . . . . . . . . . . . 5

Limitations and Delimitations of the Project. . . . . . . . 6

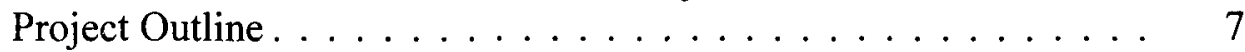

2. A THEOLOGY OF STRATEGIC LEADERSHIP TEAMS. . . . . . . . . 9

A Theology of Leadership Teams in the Old Testament . . . . . . . 9

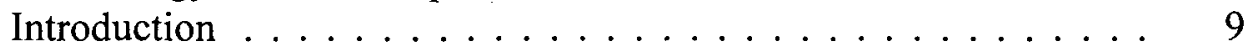

Nehemiah . . . . . . . . . . . . . . . 10

Nehemiah-A Team Leader . . . . . . . . . . . . 10

Unity of Purpose a Characteristic of Nehemiah's Team . . . 11

Teamwork Achieved More Than Nehemiah Could Have

Done Alone. . . . . . . . . . . . . . . . . 11

Nehemiah Thought Strategically. . . . . . . . . . . 13

Summary . . . . . . . . . . . . . . . 13

Moses ....................... 14

Moses Was Raised in the "Pyramid Style" of Leadership . . 14

Moses Was Divinely Led to Work with a Leadership Team. 15

Moses' Development of a Core Leadership Team. . . . . . 15

Joshua's Inclusion in Moses' Core Team Helped Train Him

as a Future Leader . . . . . . . . . . . . . . . . . . 16

Jethro's Advice Provided Training for Future Leaders . . . 17

Shared Experiences Bonded Moses' Leaders into a Team . . 18

Summary . . . . . . . . . . . . . . . . 18 
The Elders of Israel: A Divine Leadership Structure . . . . . . . 20

The Elders: An Ancient Tradition . . . . . . . . . . . . 20

The Tradition Restored after the Babylonian Captivity. . . . 20

Summary . . . . . . . . . . . . . . . . 20

A Theology of Leadership Teams in the New Testament . . . . . . . 21

Introduction . . . . . . . . . . . . . . . 21

Jesus and His Twelve Disciples $\ldots \ldots \ldots \ldots . \ldots . \ldots 21$

The Call . . . . . . . . . . . . . . . . . . 21

The Inner Core . . . . . . . . . . . . . . . . . . . 23

A Negative Aspect of the Team: Power Struggles. . . . . . . 24

Summary . . . . . . . . . . . . . . . . 25

Team Leadership and the Gifts of the Spirit. . . . . . . . . . 26

The Leadership Structures of the Early Church . . . . . . . . . . 27

A Plurality of Leaders. . . . . . . . . . . . . . . . . . 27

The Character of Leaders . . . . . . . . . . . . . . . 28

Summary . . . . . . . . . . . . . . . . . . . . 29

Principles from Ellen White Concerning Leadership Structures . . . 29

Conclusion . . . . . . . . . . . . . . . . . . 32

\section{STRUCTURE AND DYNAMICS OF STRATEGIC LEADERSHIP} TEAMS

Structure of Strategic Leadership Teams . . . . . . . . . . . . . . 33

Models for Strategic Leadership Teams . . . . . . . . . . . . 33

Members of Strategic Leadership Teams . . . . . . . . . . 36

Qualities of Team Members . . . . . . . . . . . . . . . . . . 37

Commitment to God. . . . . . . . . . . . . . . 37

Character . . . . . . . . . . . . . . . . . . . 39

Leadership Potential . . . . . . . . . . . . . . . . . 41

Complementary Aptitudes . . . . . . . . . . . . . . 42

Dynamics of a Strategic Leadership Team. . . . . . . . . . . . . 44

The Team Leader and the Team Vision . . . . . . . . . . . . 44

Team-Building Activities . . . . . . . . . . . . . 48

The Team Covenant . . . . . . . . . . . . . . . . . 48

Small-Group Activities . . . . . . . . . . . . 50

Word-Share-Prayer . . . . . . . . . . . . 51

Trust and Vulnerability . . . . . . . . . . . . . . . . 52

Toxicity within the Team . . . . . . . . . . 56

Sources of Conflict . . . . . . . . . . . . . . 56

Approaches to Conflict Resolution . . . . . . . . . 57

Differences in Personal Style . . . . . . . . . . . . . . 58

The DISC Profile . . . . . . . . . . . . . . . 59

Advantages of the DISC Profile . . . . . . . . . . 60

Limits of Conflict Resolution . . . . . . . . . . . . . . 61

Avoidance of Conflict . . . . . . . . . . . . 62 


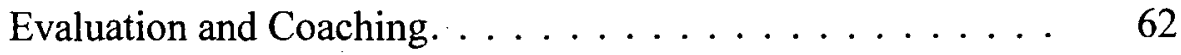

Summary . . . . . . . . . . . . . . 65

Advantages of Teams over Committees . . . . . . . . . 65

Advantages of Teams over Individual Leadership . . . . . . 67

4. STRATEGIC PLANNING BY STRATEGIC LEADERSHIP TEAMS

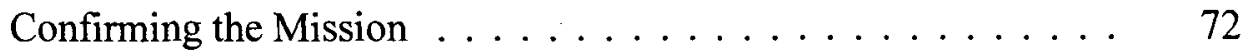

Defining the Mission . . . . . . . . . . . . . 72

Developing a Mission Statement . . . . . . . . . . . . 73

Casting a Vision . . . . . . . . . . . . . . . . 74

Vision Defined . . . . . . . . . . . . . . . . . 74

The Importance of Vision . . . . . . . . . . . . . . . . 75

Developing a Vision Statement . . . . . . . . . . . . 76

Tools for Creativity . . . . . . . . . . . . . . . . . 79

Brainstorming. . . . . . . . . . . . . . 79

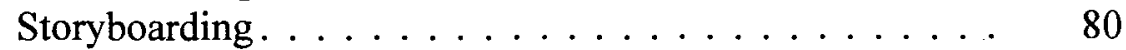

Communicating the Vision Statement . . . . . . . . . 81

Planning by Setting Objectives . . . . . . . . . . . . 82

The Importance of Planning by Objectives . . . . . . . . . 82

Principles of Planning by Objectives . . . . . . . . . . . . 84

Process of Planning by Objectives . . . . . . . . . . . 85

Common Mistakes in Planning . . . . . . . . . . . . . 88

Putting the Plan into Action . . . . . . . . . . . . . . 89

The Team Leader and Implementation of the Plan . . . . . . . 89

Communicating the Plan . . . . . . . . . . . . . . . . 91

Establishing Urgency . . . . . . . . . . . . . . . . . . . 92

Generating Short-Term Wins . . . . . . . . . . . . . 95

Building on Strengths . . . . . . . . . . . . . . 96

Evaluating the Plan . . . . . . . . . . . . . . . . . . . . 97

The Purpose of Evaluation. . . . . . . . . . . . . . . 97

The Process of Evaluation . . . . . . . . . . . . . . . . 97

Developing the Plan . . . . . . . . . . . . . . . 100

Consolidating Gains . . . . . . . . . . . . . 100

Anchoring Change into the Culture. . . . . . . . . . . 101

Planning Your Replacement . . . . . . . . . . . . . . . 102

Recognition of Accomplishments. . . . . . . . . . . . . 103

Conclusion . . . . . . . . . . . . . . . . . . . . . . 104

5. A DESCRIPTION OF THE DEVELOPMENT OF THE STRATEGIC LEADERSHIP TEAM IN THE OERLIKON SDA CHURCH . . . . . . . 106

Initial Meetings $\ldots \ldots \ldots \ldots \ldots \ldots \ldots \ldots$

Team Organization . . . . . . . . . . . . . . . . 108 
Natural Dynamics of the Team . . . . . . . . . . . . 110

Initial Frustration . . . . . . . . . . . . . . . . 110

Faith in God . . . . . . . . . . . . . . . . . . 110

A Visionary Team Leader . . . . . . . . . . . . . . . 111

Friendship between Team Members . . . . . . . . . . . 111

Willingness to Build Spiritual Foundations . . . . . . . . . 111

Willingness to Accept Responsibility . . . . . . . . . 112

Analysis of the Team . . . . . . . . . . . . . . . . . 113

Personality . . . . . . . . . . . . . . . . . . 113

Leadership Aptitudes . . . . . . . . . . . . . . . . . . . 115

Spirituality and Team Dynamics . . . . . . . . . . . . 115

Relations within the Leadership Team . . . . . . . . . . 116

Growth in Self-Understanding of the Team . . . . . . . . . . . 117

Reasons for the Successful Integration of the Team into Existing

Structures. . . . . . . . . . . . . . . . . 118

Relations with the Church Board . . . . . . . . . . . . 119

Relations with the Pastor . . . . . . . . . . . . . . . 120

Conclusion . . . . . . . . . . . . . . . . . . . . . 121

6. STRATEGIC PLANNING, ACHIEVEMENTS, AND INITIAL EVALUATION OF THE STRATEGIC LEADERSHIP TEAM . . . . 125

Strategic Planning and Achievements . . . . . . . . . . 125

Planning Objectives and Forming Strategy . . . . . . . . 125

Implementing the Small Group Strategy and Developing the Strategic Plan. . . . . . . . . . . . . . . . . 126

Communicating the Strategy. . . . . . . . . . . . . 127

Building on the Strategy . . . . . . . . . . . . . . . . 128

Promotion of Other Ministry Teams . . . . . . . . . . . . . 129

Introduction of Testimonies into the Church Service . . . . . 130

Summary . . . . . . . . . . . . . . . . . . . . 130

An Initial Evaluation . . . . . . . . . . . . . . . . . 131

Reasons for Successes . . . . . . . . . . . . . . . . 131

Successful Planning . . . . . . . . . . . . . . 131

Accountability . . . . . . . . . . . . . . 131

The Team Leader . . . . . . . . . . . . . . . . . . . 132

Mistakes . . . . . . . . . . . . . . . . . . . 132

Weakness in Long-term Follow-through . . . . . . . . . . . . 132

Integration of Future Leaders. . . . . . . . . . . . . . 133

Recognition of Accomplishment. . . . . . . . . . . . 133

Evaluation. . . . . . . . . . . . . . . . . 134

Consolidating Gains ... . . . . . . . . . . . . . . . 134

Particular Challenges . . . . . . . . . . . . . . . . . 135

Mobility . . . . . . . . . . . . . . . 135

Time . . . . . . . . . . . . . . . 135 
Discouragement and Persistence. . . . . . . . . . 135

Summary . . . . . . . . . . . . . . . . . . 136

7. CONCLUSION AND RECOMMENDATIONS . . . . . . . . 137

Introduction . . . . . . . . . . . . . . 137

A Comparison of Aims and Results. . . . . . . . . . . . . 137

Conclusions . . . . . . . . . . . . . . . 138

Leadership Teams Are a Divine Construct . . . . . . . . . 138

The Emergence of The Team Was Not as Spontaneous as

Appeared at First Glance . . . . . . . . . . . . . 139

The Team Was Productive Because Its Servant-Leaders Had

Different Aptitudes . . . . . . . . . . . . . . 140

The Team Was Able to Provide Leadership Because It Was Accepted by the Church Body . . . . . . . . . . . . . 140

Working on the Leadership Team Required Effort, Persistence, and Skill . . . . . . . . . . . . . . . . . . . 141

The Team Accomplished Far More Than an Individual Could Have Done Within the Same Time Frame . . . . . . . . 141

Work on the Team Was Satisfying and Provided Experience for the Future . . . . . . . . . . . . . . . . . . . 142

Evaluation Must be Honest and Consistent . . . . . . . . . 142

The Team Failed to Look For and Develop New Leaders . . . . 143

Integrating a Strategic Leadership Team into Existing SDA Church Structures Represents a Major Victory . . . . . . . 143

Recommendations. . . . . . . . . . . . . . . . . . . 143

The Team Leader Must Model Persistence in the Face of Discouragement . . . . . . . . . . . . . . . . . . . 144

Sign a Covenant and Reconfirm the Vision Regularly. . . . . . 144

Find a Way of Relieving the Work Load of Existing Leaders . 144

Look for Emerging Leaders and Mentor Them . . . . . . . . . 145

Find a Way of Evaluating the Progress of the Vision . . . . . 145

Communicate Regularly with the Church Body . . . . . . . 146

The Next Steps Which the Team Needs to Take . . . . . . . . 147

The Basic Principles of Team Leadership Need to be Taught . 147

Final Conclusion. . . . . . . . . . . . . . . . . 148

Appendix

1. CREATING A CLIMATE FAVORABLE TO STRATEGIC LEADERSHIP TEAMS $\ldots \ldots \ldots \ldots \ldots \ldots \ldots \ldots$

2. PERSONALITY STYLES AT A GLANCE. . . . . . . . . . . . 151

Active Roles . . . . . . . . . . . . . . . . . . . . . . . 151 


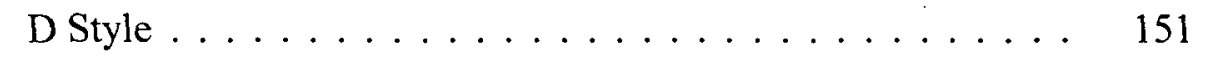

I Style . . . . . . . . . . . . . . . . . 151

Passive Roles. . . . . . . . . . . . . . . . . . . . 151

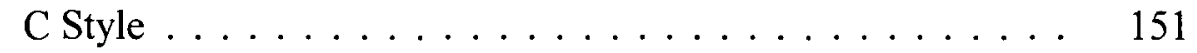

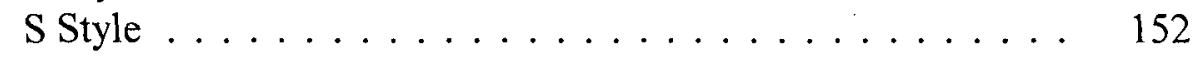

3. CHURCH MEMBERSHIP STATISTICS OERLIKON SDA CHURCH $1968-2004 \ldots \ldots \ldots \ldots \ldots \ldots \ldots \ldots \ldots$

4. AGE STRUCTURE SDA OERLIKON CHURCH JUNE $2004 \ldots 154$

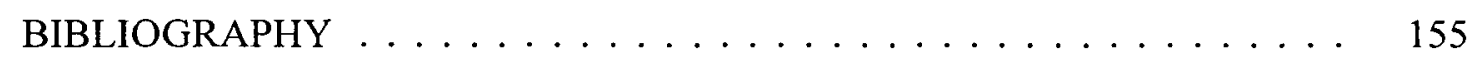

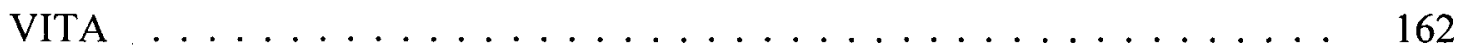




\section{LIST OF ILLUSTRATIONS}

1. Sources of Complacency . . . . . . . . . . . . . . . . . . . . 93

2. Evaluation on a Yearly Basis $\ldots \ldots \ldots \ldots \ldots \ldots$

3. Church Membership Statistics 1968-2004 . . . . . . . . . . . . 153

4. Age Structure SDA Oerlikon Church June $2004 \ldots \ldots$. . . . . . . . . 154 


\section{ACKNOWLEDGMENTS}

Not only would it be grossly ungenerous to fail to acknowledge the team work which enabled this paper to be written, it would also call into question its central thesis. The fact is, most worthwhile things in life are done as a result of combined effort and it is a great pleasure for me to recognize the work done by those who made this project possible.

Bruce Bauer was a constant source of encouragement. His support on a number of occasions not only helped overcome the sinking feeling of despair which seems common to most project writers from time to time, but whose incisive insights have enlarged my aspirations for the future. Similarly, Ed Schmidt was a continuous source of fresh concepts; many of his seemingly unlimited flow of ideas have found their way into this paper. Both of these men supported me despite being under the pressure of immensely busy schedules themselves. I am more grateful to them than I know how to put into words.

I am also grateful to the conference committee of the Swiss German Conference of SDA, particularly Paul Hofmann, Michael Urbatzka, and André Rüegg for their sponsorship at the outset of this project. Being one of the first pastors in Switzerland to be sponsored at the DMin level meant that they supported me without really knowing whether their backing would be worthwhile. I thank them for their leap of faith and hope that their trust has not been misplaced. Similarly, I am also grateful to Peter Joseit, 
Conference President during the closing stages of this project whose encouragement was a decisive factor in its completion.

My wife, Mirjam, seems to have been born with an endless supply of patience. In addition to sharing most vacations in the last five years with both me and my laptop she has also put innumerable hours into editing and formatting - truly a labor of love which I can never adequately repay. I would also like to express my gratitude to my mother and sister for cheerfully allowing me to use their homes as "hideaways" where, free from the pressures of my office desk I was able to write in peace and quiet. To my father I owe a posthumous debt of gratitude. It was his dream that I should have the chance to study at tertiary level. I look forward to thanking him on that day when our Lord makes all things new.

Finally I would like to thank God for granting me peace and joy in ministry. Without the comfort of his Spirit I would never have attempted to provide leadership in his church, let alone write a DMin project on the subject. To him be the glory. 


\section{CHAPTER 1}

\section{INTRODUCTION}

\section{Statement of Need}

The leadership of a typical European SDA local church is made up of the pastor and the church board. Church board members are usually selected from among the leaders of the various departments of the local church. This structure follows the order of the SDA Church Manual.

While the church board is usually good at managing the organization of church activities, it is rarely the best structure for leading a local church to growth. SDA churches in Switzerland at least, are usually well managed but often lack some of the most important elements of leadership, such as the ability to challenge existing practices and envision new possibilities.

It is a hypothesis of this paper that lack of strategic leadership at the local church level has resulted in both spiritual and numerical stagnation in Europe. This has occurred at a time in which a number of evangelical churches have grown and flourished. In 1948 the two Adventist congregations in Zuerich had a combined total of 444 members. ${ }^{1}$ As of October 2008 they number 375 members. Of those, approximately 60 percent attend 32.

${ }^{1}$ Thomas Domanyi, Du hast uns-Herr-gerufen (Zürich, ZH: Carta Druck AG, 1987), 
church services regularly on Sabbath. During the same time period the Pentecostal church has grown. In 1949 the Pentecostal church in Zuerich had approximately 400 members. Today it numbers 1,910 members and approximately 2,500 people attend church services each weekend. ${ }^{2}$ One of the key reasons for the growth of this evangelical community has been the presence of leadership which engaged in strategic planning.

While the decline of European Adventism cannot be attributed to lack of strategic leadership alone, there is evidence that this is nevertheless a causal factor. Exceptions to the general decline of the past four to five decades seem to support this view. Certain sections of European Adventism have seen strong, healthy growth in the last forty to fifty years. Mostly, however, this growth has been the result of the influx of one or more ethnic minority groups into the church. These accessions, while welcome, have not been the result of an intentional policy on the part of leadership. On the contrary, growth in Europe seems to have taken place more by "accident" rather than design. This fact tends to confirm the hypothesis that European Adventist churches are generally lacking in strategic leadership.

Further, European Adventism is producing too few leaders for the needs of the church. While this is probably true of large sections of the world church as well, nominating committees in Europe are increasingly frustrated by the lack of leaders who are both willing and able to take on church responsibility. Christian Schwarz identified empowering leadership as one of the eight essential characteristics of growing churches. "Leaders of growing churches concentrate on empowering other Christians for ministry.

\footnotetext{
${ }^{2}$ See Christliches Zentrum Buchegg, http://www.czb.ch/wer sind wir/geschichte/ (accessed 24 October 2008).
} 
They do not use lay workers as 'helpers' in attaining their own goals and visions. Rather ... these pastors equip, support, motivate, and mentor individuals, enabling them to become all that God wants them to be." Adventism in Europe however, seems to be producing too few leaders who are both empowered themselves and who are able to empower others.

Thus there is a need for leadership structures which promote both strategic planning and which are also able to empower leaders for the future. This paper will address that need.

\section{Purpose of the Project}

The purpose of this project is to describe a leadership model which is intended to foster growth in local churches within the German-Swiss Conference of Seventh-day Adventists. This model is called a Strategic Leadership Team. This paper will first examine inspired guidelines concerning team leadership. Using both these guidelines and also the experience gained by churches of other denominations, it will then describe a leadership team model which aims to lead local Adventist churches in Switzerland to numerical and spiritual growth. In addition, the development and work of a Strategic Leadership Team in the local SDA Church of Zuerich-Oerlikon (Switzerland) will be described. It will examine the influence of the Team on vision, strategy, and the growth of the church as far as the time limits of this paper permit.

Although the team structure is familiar to many evangelical congregations it is not

\footnotetext{
${ }^{3}$ Christian Schwarz, Natural Church Development (Carol Stream, IL: ChurchSmart Resources, 1996), 22.
} 
yet well-known within SDA circles. There have been few attempts to integrate a separate team of strategic leaders into Adventist local church structures, and as far as is known, no Adventist has yet written about these attempts. It is hoped that this project can be of service to other SDA churches which recognize that leadership is a key ingredient in evangelism.

\section{Definition of Terms}

\section{Strategic Leadership Team}

The definition of a Strategic Leadership Team used in this paper is that of George Barna. A Strategic Leadership Team "is a small group of leaders who possess complementary gifts and skills. They are committed to one another's growth and success and hold themselves mutually accountable. Together they lead a larger group of people toward a common vision, specific performance goals and a plan of action."4

There are a number of elements in this definition which need clarification. The Strategic Leadership Team is not made up of a leader who surrounds himself/herself with helpers. Each member of the group has the gift of leadership. Further, the leadership gifts of individual team members are not similar but different (complementary). There is a reason for this: "The purpose of a team is to make the strengths of each person effective and his or her weaknesses irrelevant."5

\footnotetext{
${ }^{4}$ George Barna, The Power of Team Leadership: Finding Strength in Shared Responsibility (Colorado Springs, CO: Waterbrook Press, 2001), 24.

${ }^{5}$ Ibid., 76.
} 
Although the term Strategic Leadership Team will usually be used in this paper it will, at times, simply be referred to as "the Team."

\section{Strategic Planning}

The term strategic planning as used in this paper refers to the activity of a team which seeks to glorify God by leading a church to spiritual and numerical growth. It starts with prayerful thought and the search for biblical guidance. It then seeks to envision a plan of action based on the strengths of the local church and the make-up of the local community. It is an ongoing process done by a team of respected local church leaders who also put their plan into action.

Aubrey Malphurs defines strategic planning as "the envisioning process that a point leader uses with a team of leaders on a regular basis to think and act so as to design and redesign a specific ministry model that accomplishes the Great Commission in their unique ministry context." $\mathrm{He}$ adds, strategic planning "forces pastors and leaders to think ... theologically about what they are doing and to ask ... What does the Bible say about why we are here? ... What are we supposed to be doing? . . [They] must [then] follow the thinking with action.",

\section{Leadership}

Leadership is far easier to recognize than it is to define. Skip Bell notes that "thousands of books have been written about leadership, but we still have a hard time 2005), 26 .

${ }^{6}$ Aubrey Malphurs, Advanced Strategic Planning (Grand Rapids, MI: Baker Books, 'Ibid., 28. 
understanding it." ${ }^{8}$ James Kouzes and Barry Posner cite five leadership practices as definitive of leadership. ${ }^{9}$ Barna attempts an all-encompassing list of which he says that not every leader will shine with equal brightness in each of these areas. ${ }^{10}$ In describing the work of Nehemiah as a model for leaders today, Ellen White defines leadership in practical terms.

There is need of Nehemiahs in the church today,--not men who can pray and preach only, but men whose prayers and sermons are braced with firm and eager purpose. The course pursued by this Hebrew patriot in the accomplishment of his plans is one that should still be adopted by ministers and leading men. When they have laid their plans, they should present them to the church in such a manner as to win their interest and co-operation. Let the people have a personal interest in its prosperity. The success attending Nehemiah's efforts shows what prayer, faith, and wise, energetic action will accomplish. Living faith will prompt to energetic action. The spirit manifested by the leader will be, to a great extent, reflected by the people. ${ }^{11}$

According to Ellen White church leadership involves prayer with firm and eager purpose. Leaders have the ability to lay plans and communicate them so that listeners are motivated to cooperate. This will result in energetic action. Leadership thus encompasses prayerful forethought with purposeful motivation of others to combined action.

\section{Limitations and Delimitations of the Project}

Chapter 2: The Theology of Leadership Teams, allows only the most cursory synopsis of the topic. It makes no attempt at either a systematic theology or a biblical

${ }^{8}$ Skip Bell, A Time to Serve: Church Leadership for the 21st Century (Lincoln, NE: Advent Source, 2003), 3.

${ }^{9}$ James M. Kouzes and Barry Z. Posner, The Leadership Challenge (San Francisco, CA: Jossey-Bass, 2002), 8.

${ }^{10}$ Barna, The Power of Team Leadership, 97.

${ }^{11}$ Ellen G. White, Christian Service (Washington, DC: Ellen G. White Estate, 1996), 177. 
exegesis of leadership. It simply attempts to provide an overview of the manner in which God has led his people to practice leadership on earth.

A further limitation to this paper is that of time. The description of the development and achievements of the Strategic Leadership Team in the Oerlikon SDA Church has had to be limited to two years.

In this paper the Seventh-day Adventist Church is usually referred to as the SDA Church or the Adventist Church.

\section{Project Outline}

Chapter 2 of this paper will examine biblical leadership models. It will suggest that biblical leadership is based on "team work" rather than individual charisma or traditional committee work. It will also suggest that biblical leadership is "strategic," that is, it takes time to plan and implement activities on the basis of combined prayerful forethought.

Chapters 3 and 4 will describe the elements of an ideal modern-day Strategic Leadership Team. Chapter 3 describes the make-up and the dynamics of such a team. Chapter 4 describes the core activities of Strategic Leadership Teams, that is, the process of strategic planning and the implementation of the plan.

Chapters 5 and 6 mirror chapters 3 and 4 . However, instead of describing an ideal Strategic Leadership Team these chapters will describe the development of the Strategic Leadership Team which arose within the Oerlikon SDA Church in order to address its numerical and spiritual stagnation. Chapter 5 will describe the structures and dynamics of the Team, comparing it with biblical leadership models and the models developed in 
chapter 3. It will also describe the integration of this team into the existing structures in the SDA Church.

Chapter 6 will first describe how the Team developed and implemented its strategy. Then it will analyze the successes and mistakes of the Team by comparing them with the theory in chapter 4.

Finally, chapter 7 will examine the influence of the Strategic Leadership Team on the mission and ministries of the Oerlikon SDA Church, and evaluate its stated aim of achieving spiritual and numerical growth within that congregation. It will draw lessons from the experience in the hope that this experience will be of use for strategic leadership in other churches. 


\section{CHAPTER 2}

\section{A THEOLOGY OF LEADERSHIP TEAMS}

\section{A Theology of Leadership Teams in the Old Testament}

Introduction

In the Old Testament a particularly striking leadership model is that of the lone leader. Elijah seems to have been such a leader. After his great victory on Carmel he said: "For the people of Israel have forsaken thy covenant, thrown down thy altars, and slain thy prophets with the sword; and I, even I only, am left" (1 Kgs 19:10). 'Elijah does not appear to have worked with a team of spiritual leaders. Similarly, many Old Testament leaders such as Samuel, Gideon, and Elisha seem to have been solitary voices attempting to lead alone. Leadership in the Old Testament in many cases does not seem to have involved teamwork.

Yet, as successful as the lives of these men may have been, the lone leader does not seem to have been God's leadership plan for his people. "The Bible does not give a direct admonition to provide team based leadership," "2 but under the direction of God

\footnotetext{
'All Bible references are from the Revised Standard Version (RSV) if not stated otherwise.

${ }^{2}$ Barna, The Power of Team Leadership, 74.
} 
biblical leaders have modeled it. A number of examples from the Old and New Testaments show that God used teams to lead his people. From these examples principles for team leadership today will be extracted.

\section{Nehemiah}

\section{Nehemiah-A Team Leader}

Nehemiah was a spiritual leader of vision and determination. He had the charisma, influence, and ability to do a great work alone. Yet Nehemiah chose to work with a team. Artaxerxes granted Nehemiah time to travel to Jerusalem and implement his vision of rebuilding its walls. For three days after his arrival in Jerusalem Nehemiah appears to have rested. Yet, Neh 2:11 hints at the fact that he used these three days to set up a team with which he secretly surveyed the city: "So I came to Jerusalem and was there three days. Then I arose in the night, I and a few men with me; and I told no one what my God had put into my heart to do for Jerusalem" (Neh 2:11-12, italics mine).

The fact that he took a "few men" with him shows that from the outset he worked with other, like-minded individuals. Ellen White writes: "Nehemiah had been highly honored of God, and had been entrusted with great responsibilities; but he did not, because of this, presume to act in an independent, self-sufficient manner. He selected a few persons whom he knew to be worthy of confidence, and to them he made known the circumstances that had led to his visit to Jerusalem, the object to be accomplished, and 
the plan that he purposed to employ. Thus he secured their assistance in his important undertaking."3

Evidently Nehemiah had made the choice of his fellow team members his very first task.

\section{Unity of Purpose a Characteristic of Nehemiah's Team}

The Bible tells us no more about Nehemiah's team. We do not know what the gifts, capabilities, and attitudes of its members were. There are, however a number of facts which can be deduced from this veiled reference to Nehemiah's team work.

First, it would appear that Nehemiah chose the members of his team for their unity of purpose. Jerusalem lay in ruins because the leaders of the time had become discouraged in their task of rebuilding its walls. Nehemiah could have countered their dejection by convening a meeting with them and attempting to convince them of his vision. But he did not do this. He initially ignored the established leadership and chose instead a small group of men to accompany him on his clandestine inspection of the city walls. We can only assume he chose these men for their united support of his vision of restoration. Evidently Nehemiah was determined to have a core team which was at one with his vision.

\section{Teamwork Achieved More Than} Nehemiah Could Have Done Alone

Second, Nehemiah almost certainly achieved more as a result of teamwork

\footnotetext{
${ }^{3}$ Ellen G. White, Lessons from the Life of Nehemiah (Washington, DC: Ellen White Estate, n.d.), 11.
} 
than he could have done alone. After he and his team had secretly surveyed the desolate walls of Jerusalem Nehemiah spent the rest of the night in prayer. ${ }^{4}$

On the next day he called a meeting of the people of Jerusalem, in order to speak to them. What the people heard was a carefully crafted and thoroughly prepared motivational message, designed to inspire them to sacrifice their time, energy, and money to rebuilding the walls. Nehemiah spoke in glowing terms of the goodness of God who, as an answer to his prayers, had already provided the means for rebuilding Jerusalem. He told them of the favor which he had been shown by Artaxerxes (Neh 2:17-18). But especially convincing was his detailed understanding of the task to be done. "They [the people and their leaders] knew not, neither did he tell them, of his mournful midnight circuit while they were sleeping. Nevertheless that very circumstance contributed greatly to his success. He was enabled to speak of the condition of the city with an accuracy and minuteness that astonished his hearers."

Nehemiah's team had almost certainly been a major resource in the gathering of information. Ellen White mentions Nehemiah's "accuracy" and "minuteness" in understanding the task. His precise information almost certainly came as a result of coordinated team effort and would have been difficult for Nehemiah to achieve alone. Nehemiah's exercise in motivation was to a large extent successful because of the work done by his team.

\footnotetext{
${ }^{4}$ Ibid., 12.

${ }^{5}$ Ibid., 14.
} 


\section{Nehemiah Thought Strategically}

The first indication that Nehemiah intended to lead the rebuilding the walls of Jerusalem himself occurred when he requested King Artexerxes for a leave of absence (Neh 2:5). Even at this stage Nehemiah showed evidence that he had a clear strategy already in place. When the King asked him how long he planned to be absent, Nehemiah not only appeared to have his answer ready but also had a list of the requests he needed to bring before the king in order to make his plan possible (Neh 2:7-8).

A further evidence of strategy is shown by the fact that once in Jerusalem he did not divulge his intentions at once. It was clearly his intention to stimulate the dwellers in Jerusalem to rebuild the walls themselves. His wait of three days was part of his plan to communicate his intentions at a favorable time.

A third indication that Nehemiah had a strategic plan in place is the fact that Nehemiah made a clandestine survey of the walls of Jerusalem. Nehemiah's survey was a necessary preparation to overcome possible objections to his plan. The fact that he undertook this survey in secret indicates that Nehemiah planned to surprise those opposed to or skeptical of his purpose with his clear understanding of the task ahead.

Almost at every step in the realization of his project Nehemiah showed forethought, evidence of a clearly defined strategy.

\section{Summary}

Nehemiah's use of the team structure shows a number of characteristics of team leadership. First, Nehemiah thought in terms of corporate rather than individual leadership. He did not give his reasons for so doing. It can only be assumed that he 
understood that God desired to work through a unified body rather than independent individuals. Second, he appears to have chosen leaders who were united around the common vision of rebuilding Jerusalem. Nehemiah evidently understood the importance of unity. Third, the combined efforts of the team allowed a much more detailed analysis of the situation than would have been possible if Nehemiah had worked by himself. Fourth, Nehemiah's actions show evidence of forethought, of a clearly defined strategy. This resulted in an effective presentation of the plan of action, which in turn helped convince the inhabitants of Jerusalem to accept the vision and start putting it into practice.

\section{Moses}

\section{Moses Was Raised in the "Pyramid Style" of Leadership}

Probably the best-known leader in the Old Testament was Moses. For the first forty years of his life Moses was educated in the "pyramid style" of leadership in Egypt, in which Pharaoh held supreme executive power. However, the biblical descriptions of Moses' later years lead us to assume that he rejected the pyramidal structures of Egypt for an interdependent leadership style. In leading Israel into the Promised Land, Moses worked with leadership teams.

More to the point, Moses' understanding of the necessity of team leadership was not the result of his own initiative. His understanding of leadership was divinely led. The account of the wilderness wanderings of the children of Israel in Exod 17-24 illustrates the fact that God wishes his people to be led by leadership teams rather than solely by gifted individuals. 


\section{Moses Was Divinely Led to Work with a Leadership Team}

The fact that Moses' rejection of Egyptian leadership styles was divinely led became evident when a crisis occurred during the wilderness wanderings. The children of Israel were led to Rephidim where there was no water. Exod 17 records what happened:

But the people thirsted there for water, and the people murmured against Moses, and said, "Why did you bring us up out of Egypt, to kill us and our children and our cattle with thirst?" So Moses cried to the LORD, "What shall I do with this people? They are almost ready to stone me." And the LORD said to Moses, "Pass on before the people, taking with you some of the elders of Israel; and take in your hand the rod with which you struck the Nile, and go. Behold, I will stand before you there on the rock at Horeb; and you shall strike the rock, and water shall come out of it that the people may drink." And Moses did so, in the sight of the elders of Israel (Exod 17:3-6, italics mine).

It is not known how many of the elders of Israel Moses took with him when he struck the rock. Possibly he took as many as seventy (Exod 24:9). Of first importance is the fact that God instructed Moses to take the step of involving other leaders in the direction of the people. It does not seem to have been God's plan for Moses to lead alone.

\section{Moses' Development of a Core Leadership Team}

At what point Moses began to understand God's plan for interdependence of leadership is not clear. However in Exod 17:8-16 it is evident that Moses understood its importance:

Then came Amalek, and fought with Israel in Rephidim. And Moses said unto Joshua, "Choose us out men, and go out, fight with Amalek: tomorrow I will stand on the top of the hill with the rod of God in mine hand." So Joshua did as Moses had said to him, and fought with Amalek: and Moses, Aaron, and Hur went up to the top of the hill. Whenever Moses held up his hand, Israel prevailed; and whenever he lowered his hand, Amalek prevailed. But Moses' hands grew weary; so they took a stone and put it under him, and he sat upon it, and Aaron and Hur held up his hands, one on one side, and the other on the other side; so his hands were steady until the going down of 
the sun. And Joshua mowed down Amalek and his people with the edge of the sword (Exod 17:8-13).

Moses took key leaders with him to observe Joshua's handling of the battle. He does not appear to have done so as a result of a direct command from God but of his own volition. However, God clearly showed Moses that Israel would have been defeated had Aaron and Hur not been with him to hold up his hands. As a result, Moses must have realized not only the dependence of Israel on Divine power but also his own dependence on other leaders.

This is the first time that Joshua and Hur are mentioned as leaders in Israel. It seems evident from this incident that Moses had started to develop a core leadership team. At this point it included Hur and Joshua in addition to Aaron.

\section{Joshua's Inclusion in Moses' Core Team Helped Train Him as a Future Leader}

The inclusion of Joshua in Moses' core team is significant. Joshua was a much younger man than Moses, belonging to the next generation of Israelites (Exod 33:11). Moses may have initially included him in his core team for his fighting abilities because Moses himself was at an age in which he was too old to do battle. But it may also be that Moses included Joshua as a means of training him for the future leadership of Israel.

It was certainly God's intention to train Joshua for future leadership. After the battle God instructed Moses to write the story of the encounter with Amalek in a book:

"And the LORD said to Moses, 'Write this as a memorial in a book and recite it in the ears of Joshua, that I will utterly blot out the remembrance of Amalek from under heaven"" (Exod 17:14). 
God's express purpose in commanding Moses to document his intention of destroying Amalek was to remind Joshua of God's will. Even though it was to be forty years before Joshua was to take on the leadership of Israel, God was evidently grooming Joshua to be the leader of the next generation of Israelites. Being part of Moses' core team provided Joshua with on-the-job training for his future task and provides a classic example of empowering leadership.

At the heart of Joshua's training lies the concept of leadership redundancy. God's reminder to Moses that Joshua would one day lead Israel was also a reminder that Moses would one day no longer be able to do so. The training of a future leader was necessary because Moses would one day have to hand over the reins of leadership.

\section{Jethro's Advice Provided Training for Future Leaders}

In Exod 18, Moses was wisely advised by his father-in-law, Jethro, to delegate responsibility for the administration of justice in Israel. This involved a huge reorganization in the manner in which Moses had worked up until this point in time. Jethro's advice called for a change in management rather than a change in the leadership in Israel, yet by including others in his work Moses once again provided training for future leaders. Jethro said: "And you shall teach them the statutes and the decisions, and make them know the way in which they must walk and what they must do" (Exod 18:20). Working with others rather than on his own meant that Moses was able to train future administrators on the job. 


\section{Shared Experiences Bonded Moses' \\ Leaders into a Team}

In Exod 24 God confirmed his plan for leadership by team rather than by an individual: "Then Moses and Aaron, Nadab, and Abihu, and seventy of the elders of Israel went up, and they saw the God of Israel; and there was under his feet as it were a pavement of sapphire stone, like the very heaven for clearness. And he did not lay his hand on the chief men of the people of Israel; they beheld God, and ate and drank" (Exod 24:9-11).

Moses and his elders were treated to one of the most overwhelming and inspiring divine encounters ever given to mankind after the fall. By appearing in his glory, God created a sense of awe among the elders, unifying them through a most impressive common experience. After this experience the elders then ate and drank together. There can be no doubt about their topic of conversation at that meal. Both the revelation of God's glory and the chance to talk about it among themselves directly afterwards would have had the effect of welding them together as a group and fostering a common vision among this team of leaders. Teamwork and unity have always been God's aims for the leadership of his people. This incident illustrates how God promoted it at the time of Moses.

\section{Summary}

There are a number of lessons which can be drawn about leadership teams from the life of Moses in Exod 16-24. First, shared leadership is not a human but a divine construct. Although Moses was brought up under a leadership system which emphasized individualism, when called by God to lead Israel he involved others in the leadership of 
Israel. This he did, not as a result of his own volition but because God instructed him to draw others into the leadership process. This is the most valuable lesson to be gained from examining the story of Moses' leadership.

Second, the experience of Moses demonstrates the importance of a core leadership team. In addition to the seventy elders, Moses also depended on the collaboration of Joshua, Hur, and Aaron to defeat Amalek. Without the support of his core leaders Moses' strength would have been inadequate for Israel to succeed. Even such a godly leader as Moses needed the support of his closest advisors.

Third, the defeat of Amalek and the restructuring of the management of Israel show both the importance and the method of training future leaders. God's instructions to Moses concerning Joshua show that he evidently took the grooming of future leaders seriously. Further, he showed how it was to be done: not by long years of education in a distant seminary but by on-the-job training.

Fourth, the life of Moses illustrates the importance of a common vision among the leadership team. A common vision among the seventy elders was fostered by God himself. In Exod 24 the elders were privileged to catch a glimpse of God's glory. Afterwards he provided them with a meal at which they could discuss and celebrate their experience. Common vision among leaders is fostered by common activities and also by time for socializing and celebrating common achievements. 
The Elders of Israel: A Divine Leadership Structure

\section{The Elders: An Ancient Tradition}

Nowhere in the Old Testament does God prescribe a particular form of leadership. The tradition of communal leadership among the people of God, however, is very ancient. When Moses came to Pharaoh to request the release of his people from Egypt, he was told by God to first counsel with the elders of Israel (Exod 3:16-18). This is the earliest mention of any form of leadership among the people of Israel.

\section{The Tradition Restored after the Babylonian Captivity}

After the Exodus, Moses appears to have integrated these elders into his own leadership structures. Theoretically, at least, communal leadership by elders remained in force in Israel until the ninth century B.C. when Israel demanded governance by a king. Under the influence of its kings Israel went through times of both great success and dreadful apostasy. Kingly power resulted in the elimination of the ten northern tribes and the captivity of Judah. After the Babylonian captivity however, Ezra seems to have restored governance by elders again (see Ezra $5: 5 ; 6: 7 ; 6: 14$ ). This restoration is a remarkable rejection of kingly power and strongly suggests that the structure of interdependent leadership is of divine origin. The fact that Paul under divine inspiration advised Titus (Titus 1:5) to appoint elders in every church that he had raised underscores this assumption.

\section{Summary}

Communal leadership, rather than leadership by one individual is based on a 
counsel of elders, a very ancient tradition. Further, its reestablishment after the Babylonian captivity and integration into New Testament structures indicates that plurality of leadership is part of God's plan for his people.

\section{A Theology of Leadership Teams in the New Testament}

\section{Introduction}

Just as there is little direct divine instruction in the Old Testament concerning leadership structures for the people of God, so there are relatively few divine commands in the New Testament concerning the leadership of the church. Rather than prescribing leadership forms the New Testament illustrates and teaches principles of leadership. These principles must be deduced from the narratives and instruction of the New Testament.

\section{Jesus and His Twelve Disciples}

\section{The Call}

Luke describes the call of the twelve disciples in the following words: "In these days he went out to the mountain to pray; and all night he continued in prayer to God. And when it was day, he called his disciples, and chose from them twelve, whom he named apostles" (Luke 6:12-13).

Jesus appears to have continued the Old Testament tradition of communal leadership. Until he called them from among the mass of his followers, the twelve were described as disciples. A disciple is "one who is being influenced." But with their call

\footnotetext{
${ }^{6}$ Gareth Weldon Icenogle, Biblical Foundations for Small Group Ministry (Downers Grove, IL: InterVarsity Press, 1994), 119.
} 
they became apostles. "An Apostle is one who is sent forth" (italics mine). ${ }^{7}$ Jesus' new designation for the twelve implies their new leadership role. From being followers they became leaders.

Ellen White has described the calling of the twelve disciples as "the first step... taken in the organization of the church that after Christ's departure was to be His representative on earth." ${ }^{98}$ The call showed the type of leadership structure that Jesus envisaged for His representatives in this world. By calling twelve disciples Jesus showed that he was not willing to use the existing power structures of his day. By the time of Christ the group leadership structures exemplified by Moses had been distorted by the Jews into leadership patterns which used the hierarchy of the Roman Empire as their role model. This was not a model which Jesus chose to emulate. Nor, in pouring new wine into new wineskins, did Jesus develop leadership structures based on a type of religious monarchy: there is no inspired evidence that Peter was divinely ordained to be the first Pope. Instead, this first organizational step illustrates what is probably the most important principle of church organization: Jesus' plan for his church involves a plurality of leaders.

While the calling of the twelve does not provide direct evidence for team leadership it does suggest that Jesus did not expect his disciples to work alone. Further reading of the gospels confirms that Jesus always expected his disciples to work together. The fact that Jesus called twelve disciples is suggestive of team leadership without it being directly commanded.

\footnotetext{
${ }^{7}$ Ibid., 120.

${ }^{8}$ Ellen G. White, The Desire of Ages (Mountain View, CA: Pacific Press, 1940), 291.
} 
The call is suggestive of another detail concerning church leadership. Before choosing his future leaders Jesus spent a night in prayer. In prayer he asked for the guidance of his Father in choosing from among his numerous followers those who would lead his church in the future. The importance Jesus placed on seeking the will of God is an example for all leaders looking for co-leaders.

\section{The Inner Core}

Like Moses, Jesus actively fostered the development of his inner core of disciples, of Peter, James, and John. In Mark 3:16-17 he gave these three disciples special namesa fact not mentioned about the other nine disciples. Additionally, Jesus deliberately chose the core to accompany him on three separate occasions when he left the other nine behind (Mark 5:37; 9:2; 14:33). John Ott suggests the following reasons for Jesus' intentional development of his inner leadership circle. "The leadership core is the key to the team's ongoing development of leadership. It is most likely that from this core will arise the person who will succeed the present leader or be sent to lead a new ministry team.... In effect, members of the leadership core function as leadership apprentices rather than as mere assistants. ... The goal of the assistant is to help the leader. The goal of the apprentice is to learn to lead and to work to become like the leader in terms of responsibility, wisdom and vision." 9

\footnotetext{
${ }^{9}$ E. Stanley Ott, Transform Your Church with Ministry Teams (Grand Rapids, MI: Eerdmans, 2004), 69.
} 
Like Moses, Jesus fostered his future leaders by developing an intimate relationship with an inner core of disciples. ${ }^{10}$

A further advantage, which the formation of an inner core created, was emotional and spiritual support in times of crisis. Jesus turned to Peter, James, and John to support him in his sufferings in Gethsemane. Just as Moses needed the support of Aaron and Hur in the battle against Amalek, so Jesus turned to his core team for support in his battle against temptation.

\section{A Negative Aspect of the Team: Power Struggles}

The Gospels remind us repeatedly of the power struggles that went on among the disciples. After James and John had asked Jesus for the privilege of being his closest advisors, Jesus said this: "You know that those who are supposed to rule over the Gentiles lord it over them, and their great men exercise authority over them. But it shall not be so among you; but whoever would be great among you must be your servant, and whoever would be first among you must be slave of all. For the Son of man also came not to be served but to serve, and to give his life as a ransom for many" (Mark 10:44). Jesus

\footnotetext{
${ }^{10}$ Ellen White underlines the fact that the disciples were trained not in the first instance by a classroom-type of instruction but by association with Jesus: "The most complete illustration of Christ's methods as a teacher is found in His training of the twelve first disciples. ... To them, above all others, He gave the advantage of His own companionship. Through personal association He impressed Himself upon these chosen colaborers. . . In the training of His disciples the Savior followed the system of education established at the beginning. The Twelve first chosen, with a few others who through ministry to their needs were from time to time connected with them, formed the family of Jesus. They were with in the house, at the table, in the closet, in the field. They accompanied Him on His journeys, shared His trials and hardships, and, as much as in them was, entered into His work." Ellen G. White, Education (Mountain View, CA: Pacific Press, 1952), 84-85.
} 
consistently taught a form of servant-leadership. This was one of the antidotes to the power struggles that went on within his leadership team and was vital to the cohesion of the church leadership after his death.

In addition, Jesus invited his disciples to learn from him in their use of power and influence: "Whoever would be great among you must be your servant, and whoever would be first among you must be slave of all. For the Son of man also came not to be served but to serve, and to give his life as a ransom for many" (Mark 10:43-45, italics mine).

Jesus not only adopted the principle of team leadership, he also demonstrated a way to overcome the potential instability of the group leadership structure. The antidote to power struggles within the group was to adopt the form of servant-leadership which Jesus both taught and modeled himself.

\section{Summary}

By deliberately choosing an alternative to the typical power structures of his time Jesus confirmed the team structure as a divine construct. Within his team structure Jesus also developed an inner core. One of the reasons for this development was to ensure an ongoing leadership after his departure. Another reason appears to have been Jesus' desire for dependence on his core team for emotional and spiritual support in times of crisis. Finally, Jesus both taught and modeled servant-leadership as a way of dealing with potential power struggles amongst team members. 
Team Leadership and the Gifts of the Spirit

Perhaps more than any other New Testament teaching, the doctrine of spiritual gifts teaches the interdependence which lies at the heart of team leadership. The apostle Paul used the startling metaphor of the human body to illustrate this principle.

For the body does not consist of one member but of many. If the foot should say, "Because I am not a hand, I do not belong to the body," that would not make it any less a part of the body. And if the ear should say, "Because I am not an eye, I do not belong to the body," that would not make it any less a part of the body. ... Now you are the body of Christ and individually members of it. And God has appointed in the church first apostles, second prophets, third teachers, then workers of miracles, then healers, helpers, administrators, speakers in various kinds of tongues (1 Cor 12:14-16; 27-28).

In likening the church to a body in which each organ has a job to do, Paul warned against independence ("Because I am not a hand, I do not belong to the body"). God created the different parts of the body to complement each other. Just as interdependence was God's plan for the body so it is his plan for the church. If this is true of the church as a whole, it must also be true of the leadership of the church.

The doctrine of spiritual gifts also shows the necessity of diversity of gifts within teams. An ideal team is made up of a collection of people who think alike but have complementary gifts and skills. The differences in their gifts produce well-rounded results because the weaknesses of one member are cancelled out by the strengths of others.

Because of the emphasis on interdependence and its teaching of the necessity for differing gifts within a team the doctrine of spiritual gifts forms an important basis for the practice of team leadership. 
The Leadership Structures of the Early Church

\section{A Plurality of Leaders}

While order was important for the apostolic church, matters of governance and organization seem to have been secondary rather than primary issues. Nowhere does the New Testament provide a list of Ten Commandments for church government, nor is there much information about how the first Christians went about selecting people for church office. One fact emerges very clearly however: leaders were always referred to collectively. There is never a reference to a church with just one elder or one leader.

The first reference to New Testament elders concerns the church in Jerusalem. Paul and Barnabas were sent to Judea to bring famine relief to the church in Jerusalem. They were to hand over the gifts of the church in Antioch to the elders in Jerusalem (Acts 11:30). Paul and Barnabas also ordained elders "in every church" (Acts 14:23) which they raised up on their first missionary journey. Similarly, Paul admonished Titus to "appoint elders in every town as I directed you" (Titus 1:5). In Ephesus Paul prayed for the elders of the church. Here the word elder (presbuteros) and bishop (episkopos) appear to be used interchangeably (cf. Acts 20:17 and Acts 20:28). ${ }^{11}$ The church appears to have continued the Old Testament practice of leadership by a council of elders. It never had a human CEO.

However, although the leadership of the early church is referred to in the plural there seems to be an indication that one of the leadership team acted as a "first among equals." On the day of Pentecost Luke described "Peter, standing with the eleven"

\footnotetext{
"SDA Bible Dictionary (1960), s.v. "Elder."
} 
(Acts 2:14). When Paul went to Jerusalem to give an account of his third missionary journey he visited "James; and all the elders were present" (Acts 21:18). Mark Conner suggests that the New Testament pattern of Prima inter Pares was based on Old Testament leadership patterns: "This may have emerged from the Old Testament model of leadership where we have Moses and the elders (Exod 4:29; Num 11:16), Joshua and the elders (Josh 24:1; Judg 2:7), and also David and the elders of Israel (2 Sam 5:3; $1 \mathrm{Chr}$ $15: 25) . " 12$

It is only later in the history of the church that the rise of a "monarchical bishop" is mentioned who was "the unquestioned leader of the community of a given city."13

While all these references to leadership in the New Testament are descriptive rather than proscriptive they nevertheless confirm the New Testament pattern of collective responsibility.

\section{The Character of Leaders}

One of the few prescriptive aspects of leadership in the New Testament refers to the character of leaders. Jesus had warned his disciples that the fruit (actions, character) of a prophet was more important than his words (Matt 7:20). This warning evidently guided the early church in its choice of leaders. That the church required men of the highest character as its leaders is first indicated in Acts 6, where the apostles encouraged the disciples in their choice of deacons to choose "men of good repute, full of the Spirit

\footnotetext{
${ }^{12}$ Mark Conner, “A NT Pattern of Church Leadership," Internet Essay, September 2001, 8, http://jmm.aaa.net.au/articles/9305.htm (accessed 29 December 2007).

${ }^{13}$ Kevin Giles, Patterns of Ministry among the First Christians (Melbourne, Australia: Collins Dove, 1989), 42.
} 
and of wisdom" (Acts 6:3). Later, the apostle Paul laid down clear guidelines for the choice of church leaders. These included evidence of good management in their family life, discipline in their personal morals, and a good reputation as testified by nonChristians in addition to their ability to teach the Word of God (1 Tim 3:2-7; Titus 1:5-9). The influence of the Holy Spirit on the leaders' life had to be shown in their lifestyle. The character of a leader was decisive in determining fitness to lead.

\section{Summary}

The New Testament does not proscribe any single form of leadership structure. The examples of leadership which the New Testament describes lead us to search for principles rather than specific forms of church government. The first principle of leadership in the early church is the principle of plurality of leaders. Second, the New Testament also appears to suggest that the early church accepted the principle of a leader of leaders. Third, the New Testament emphasizes the necessity of a godly character in influencing the choice of church leadership. Finally, it appears evident that the New Testament leadership forms were largely based on Old Testament models.

\section{Principles from Ellen White Concerning Leadership Structures}

In December 1892 Ellen White wrote a letter to O. A. Olsen, President of the General Conference at the time, entitled "Organization." "It It described the work done by the pioneers both in forming the Advent Movement and then in organizing it.

\footnotetext{
${ }^{14}$ Ellen G. White, Christian Experience and Teachings (Mountain View, CA: Pacific Press, 1922), 192-205.
} 
The initial aim of the pioneers after the disappointment in 1844 was to search for Bible truth. Later, in the 1860s their aim was to organize the scattered band of Sabbathkeeping Adventists into an organized church. Ellen White's description of their efforts in her letter to Olsen illustrated not merely some important principles of organization but also a number of significant principles of church leadership. The most relevant part of this communication can be found in White's book (Christian Experience and Teachings), chapter 33.

First, it is evident from Ellen White's description that the pioneers had, in effect, formed a leadership team.

My husband, with Elders Joseph Bates, Stephen Pierce, Hiram Edson, and others who were keen, noble, and true, was among those who, after the passing of the time in 1844 , searched for the truth as for hidden treasure. We would come together burdened in soul, praying that we might be one in faith and doctrine; for we knew that Christ is not divided. One point at a time was made the subject of investigation. The Scriptures were opened with a sense of awe. Often we fasted, that we might be better fitted to understand the truth. After earnest prayer, if any point was not understood, it was discussed and each one expressed his opinion freely; then we would again bow in prayer, and earnest supplications went up to heaven that God would help us to see eye to eye, that we might be one, as Christ and the Father are one. Many tears were shed. We spent many hours in this way. Sometimes the entire night was spent in solemn investigation of the Scriptures, that we might understand the truth for our time. ${ }^{15}$

The above quotation shows the importance which the pioneers placed on the principle of plurality of leadership. No one person was given the right to form fundamental beliefs by himself. Even the presence of an acknowledged prophetess in their midst did not do away with the sheer hard work which the pioneers put into their mutual Bible study. While James White clearly led out in the formation of the fledgling movement it was in prayer and discussion with other leaders that the vision was created.

\footnotetext{
${ }^{15}$ Ibid., 192-193.
} 
Also impressive in this account is the dedicated persistence which the early pioneers invested in their creation of their goal. They invested large portions of their time in prayer, discussion, fasting, and Bible searching. Even entire nights were spent this way. This they did in order to create a clear understanding of their common ground, their common vision. It was of first importance for the pioneers to find unity of purpose before moving forward with their plans. The quotation illustrates the importance of a second principle for leadership teams: the necessity of unity of purpose, of a common vision in order to achieve goals as a team.

A third principle of leadership practiced among the pioneers in the 1840 s was the certainty of divine leadership. The pioneers prayed for and reckoned with the intervention of the Holy Spirit. Their prayers were not mere formalities but earnest pleas for his leading. From the above quotations it is clear that the pioneers considered Jesus himself to be their unseen guest, guiding their thoughts and decisions. They were certain of his intervening guidance.

A fourth principle was that of humility among the leadership. The pioneers showed personal humility both in accepting God's will for their work and also in their willingness to accept the opinions of others when these were shown to be more valid than their own.

The letter "Organization" by Ellen White gives its reader an insight into the type of leadership which the pioneers gave to the early SDA Church. Their leadership was in harmony with the principles of biblical leadership already mentioned in this paper. 


\section{Conclusion}

The limitations of this chapter have allowed only the most cursory overview of the topic of team leadership in the Bible. It has made no attempt at either a systematic theology or a biblical exegesis of leadership. It has simply sought examples of the way inspired leaders practiced leadership among God's people on earth.

When thinking of leadership in the Bible we tend to think of outstanding individuals. However, perhaps more often than not, the principle of plurality of leadership is found both in the New and Old Testament. Many great leaders worked with teams. In the Old Testament the examples of Moses, Nehemiah, and the elders of Israel demonstrate this principle. In the New Testament the organizational structures of the early church, as well as the teaching of the gifts of the Spirit underscore this basic idea. To paraphrase an old song, the biblical approach to leadership can be summed up in the words: "Anything you can do we can do better." Leadership teams represent the recovery of an ancient and biblical pattern of ministry. They are a divine construct. 


\section{CHAPTER 3}

\section{STRUCTURE AND DYNAMICS OF STRATEGIC LEADERSHIP TEAMS}

\section{Structure of Strategic Leadership Teams}

Chapter 2 aimed to show from inspired sources that God's people have ideally been guided by teams of leaders. Further, its purpose was to demonstrate that those leaders thought strategically. This chapter describes the make-up and the dynamics of an ideal modern-day Strategic Leadership Team which is based on inspired examples.

\section{Models for Strategic Leadership Teams}

There are no models for Strategic Leadership Teams to be found in the SDA Church Manual. Executive leadership of an Adventist church is usually provided by the church board. While some church boards are able and willing to think strategically, many are not. In most churches the Strategic Leadership Team will have to be formed as a separate entity from the church board. It is, however, more than likely that the majority of members on the church board are not in favor of having another team working within the church in a leadership role. In order to avoid the potential conflict inherent in this situation there are a number of models which can be used in order to initiate strategic thinking and action. 
First, assuming that it is the senior pastor who wishes to initiate strategic planning, it is sometimes possible to use the church board as a Strategic Leadership Team. Whether this is feasible or not depends on the size of the board and the attitudes and capabilities of the individual board members. The members of the church board should exhibit the attitudes outlined in the section "Qualities of Team Members" (page 37) in this chapter. Further, they should be willing to invest the time and effort necessary to engage in strategic thinking as suggested in the section "Team-Building Activities" (page 48). In many cases however, a church board will be too large to be used as a Strategic Leadership Team.

Another option is to use a team of elders as a Strategic Leadership Team. For some churches this may be a viable alternative. Similar conditions to those mentioned in the previous paragraph apply to a Strategic Leadership Team made up of church elders.

If, however, neither the church board nor the team of elders is able or willing to function as a Strategic Leadership Team the pastor has other alternatives. A third option would be to set up a personal ministries group which would then function as a Strategic Leadership Team. Usually, when it is explained that the task of the Strategic Leadership Team is mission and vision rather than the running of the church, most church leaders will support the creation of such a team. In this case, however, the competencies of the Strategic Leadership Team and its relation to the executive structures of the church will need to be established. Questions such as finance and issues of power will need to be discussed. It is important to answer these questions at the outset because in many cases the vision of the Strategic Leadership Team will ultimately transform most aspects of church life. Members of the board may well feel "manipulated" by the momentum the 
Strategic Leadership Team creates. If the Strategic Leadership Team is independent of the church board it is advisable to ensure that two or three key board members are also members of the team. Without the support of these key leaders the Strategic Leadership Team will almost certainly encounter disheartening opposition from established church leadership.

A fourth model is the Nehemiah option. In churches in which the church board is both adamantly opposed to change and also to any challenge to its own influence, then the pastor will be forced to circumvent established leadership structures. Just as Nehemiah set up a Strategic Leadership Team which was independent of the leaders in Jerusalem so the pastor will look for willing volunteers outside of the recognized leadership structures. With this team he or she will form an evangelistic strategy. ${ }^{1}$

In this case team members need to be selected with very special care. They will not be people who are merely looking to change the way church is done. They will be members who exhibit loyalty to the church, its Lord, and its mission. Many of those who are invited to be part of the team will almost certainly be doing a great deal of work for their church anyway.

Once the strategy of the Strategic Leadership Team begins to take shape the pastor will act with much prayer and personal heart-searching and will not use the ideas and vision of the Strategic Leadership Team to deliberately split the church. In a Christlike manner the pastor will patiently introduce the concepts and vision of the Strategic Leadership Team to the established leadership in order to gain their cooperation. appendix 1 .

${ }^{1}$ For suggestions concerning the creation of a team under such circumstances see 
There is a final model for the creation of a Strategic Leadership Team. It can be termed the "spontaneous model" and occurs when a group of concerned church members pool their time, talents, and creativity in order to meet the needs of a congregation without being prompted to do so by established leadership. Often such a group will come together as the result of a crisis. When such a group forms spontaneously, established church leaders can easily feel threatened and criticized by new ideas which arise outside of their own ranks. However, if the existing leadership is willing to work in an integrative manner it can be responsible for fostering a new leadership team within the church. In the case of the Oerlikon SDA Church, discontent with the evangelistic efforts of existing. leadership was a major motivation in the spontaneous development of a group which eventually became a Strategic Leadership Team. Existing leadership showed a breadth of vision in its readiness to enter into discussion with this group and further, by channeling its ideas into positive action.

\section{Members of Strategic Leadership Teams}

Usually the senior pastor will select the team, although this will not always be the case. The following principles are helpful in this respect.

First, the leader of the Strategic Leadership Team is responsible for choosing the individual members. If the choice of the Strategic Leadership Team is left to a committee then it is almost certain that unsuitable people will be selected. Second, the leader-and here again it is assumed that the senior pastor will take on the leadership of the Strategic Leadership Team - will look for missionary minded, influential lay members who are respected by all sections of the church. Third, the leader will talk to the possible members 
about the task and ask for their time. Fourth, he will keep the team small. Malphurs advises involving "around twenty-five to thirty leaders" in the work of a Strategic Leadership Team. ${ }^{2}$ This may be necessary in very large churches which number their membership in thousands. In the vast majority of churches, however, the leader will be well advised to restrict the team to six individuals or less. A leadership team, which grows too large to engage in small group activities, will lose the advantages which small group dynamics bring. Fifth, the leader must be prepared to be disappointed. One of the frustrations of setting up a Strategic Leadership Team is that often those members who are best suited to the work are those with the least time. The leader must be prepared for refusals and be willing to work with less than ideal material. Often, however, once the ideas and vision which the Strategic Leadership Team creates begin to catch on the leader will notice greater enthusiasm for work on the team. Often, too, a person who practices wise leadership will gather other leaders around him. The team should therefore remain open for the admission of new members. Its members should develop a "talent-spotting" mentality in which they are constantly on the lookout for potential leaders who can be mentored by the Team. The work that the team does together is described in chapter 4 of this paper.

\section{Qualities of Team Members}

\section{Commitment to God}

What are the qualities to look for in the members of a Strategic Leadership Team?

\footnotetext{
${ }^{2}$ Malphurs, Advanced Strategic Planning, 60.
} 
Even before one looks for skills or giftedness, members of the team should display certain attitudes. The most important attribute in church leadership is a heart committed to God. Churches do not merely need leadership, they need spiritual leadership. Ben Maxson emphasizes the necessity of a leader having "died to self." $\mathrm{A}$ leader who has not committed his or her life to God will inevitably set the wrong priorities for a church. Commitment to Christ is a core value. To some extent commitment to Christ is also an ideal value. We are all hindered by our humanness, our brokenness, and our weakness. Yet the lives of leaders whose task it is to influence others should exhibit transparency in their commitment to follow the leading of the Spirit of God.

Because commitment is a value and not a behavior its presence or absence is not always immediately apparent. But it is evidenced by behavior over time. One of the evidences of committed leaders is that their actions match their words. They keep their promises. Leaders inspire trust not just because they say they honor God but because their lifestyles reflect their faith. One of the evidences that the future members of the Strategic Leadership Team in the Oerlikon Church were committed to God was their commitment to a regular and earnest prayer life. A further evidence of their commitment was their willingness to invest time in reading books on Christian leadership and reflecting on how to put the principles they read about into practice.

Committed Christians are also aware of the purity of Jesus and the resulting sinfulness of sin. They do not treat issues such as Sabbath keeping, cohabitation, or

${ }^{3}$ Ben Maxson, "Geistliche Leiterschaft" (paper presented at the Spiritual Leadership Seminar in Kaprun [Austria], 24-17 September 2001), 12. 
adultery lightly. On the contrary, they recognize the necessity for sincere confession and turning away from sin both in their own lives and in dealing with others. They will have experienced the joy of repentance which confession and sanctification bring (Ps 91:12) and the absolute necessity of dependence on the presence of Christ in their own lives. They will lift up Christ as their model, whom they admire, respect, and have chosen as their Lord. As leaders they will be committed to seeking souls and to working for their transformation. This is more important to them than merely tinkering with the machinery of church.

The reason for selecting leaders who are committed to Christ is that leaders act as models. The character of the leadership will be caught by the congregation.

\section{Character}

Bill Hybels suggests that team members must have the three "Cs ": "character, ... competence, and ... chemistry" ${ }^{4}$ (by chemistry he means a personality which by and large harmonizes with the other team members). Of these, his number one priority is a godly character. ${ }^{5}$ The reason Hybels and other authors underline the importance of character is very simple. The Bible stresses this aspect of leadership more than any other:

This is why I left you in Crete, that you might amend what was defective, and appoint elders in every town as I directed you, if any man is blameless, the husband of one wife, and his children are believers and not open to the charge of being profligate or insubordinate. For a bishop, as God's steward, must be blameless; he must not be arrogant or quick-tempered or a drunkard or violent or greedy for gain, but hospitable, a lover of goodness, master of himself, upright, holy, and self-controlled; he must hold firm to the sure word as taught, so that he may be able to give instruction in sound doctrine and also to confute those who contradict it (Titus 1:5-9).

\footnotetext{
${ }^{4}$ Bill Hybels, Courageous Leadership (Grand Rapids, MI: Zondervan, 2002), 81.

${ }^{5}$ Ibid.
} 
The stipulations which the Word of God lays down as prerequisites for the choice of elders all have to do with good character.

What character traits should churches look for in choosing spiritual leaders? First, they should look for evidence of a love for and obedience to Jesus and his Word. In private conversations, small-group meetings, Sabbath school discussion, and association with fellow believers this character trait will become evident.

Second, loyalty to the church is a must. Faithful attendance at church meetings (Heb 10:25) and participation in its aims is one evidence of loyalty. A willingness to serve the church in various capacities is further evidence of loyalty. This does not mean that the prospective leader is uncritical of the church. On the contrary, loyalty to the aims of the SDA Church can mean that a person expresses his frustration with the status quo. This frustration can often be the sign that a person has a vision for service. Jesus was loyal to his "church" (Luke 4:16) but did not attempt to hide his criticism of its leaders or practices. The future members of the Strategic Leadership Team of the Oerlikon Church were loyal to the Adventist Church and its beliefs, but were critical of the lack of evangelistic leadership which its leaders were providing. It was partly the depth of their frustration in this respect which caused their desire for change.

Third, faithfulness in accomplishing tasks, reliability, willingness to do what is promised, integrity, and humility are also characteristics that are necessary.

The issue of character in leadership is vital. However, while emphasizing the necessity of a Christian character it is fatal to forget that Jesus chose people not on the basis of what they were but what they could become. People with obvious immaturities but who are committed to following Jesus should not automatically be left out of 
consideration as team members. Jesus was generous in his willingness to call and send unlikely candidates for his Kingdom; his church can afford to be generous as well. It is important, however, not to confuse immaturity with sin. Unwillingness to confess and refrain from sinful lifestyles automatically excludes members from leadership. On the other hand the trust connected with the responsibility of leadership has often helped immature people become capable of higher things.

\section{Leadership Potential}

Leadership teams are not composed of one leader and a group of helpers. A Strategic Leadership Team is made up of a number of individuals, each of whom is a leader. However, this statement needs to be qualified at the outset. Not all leaders are

- born. Leadership competencies can be learned. Many people develop leadership qualities as a result of experience. For this reason the Strategic Lèadership Team can include potential leaders, whose leadership gifts are latent rather than overt. The team offers them an opportunity to develop their leadership skills.

In looking for potential leaders, Glen Martin and Gary McIntosh have memorably described risk-taking as one of the key leadership skills which sets leaders apart from other people: "There are three types of leaders-risk-takers, caretakers, and undertakers. ${ }^{, 6}$ The risk-takers are leaders.

Other potential leaders can be identified by the fact that they are provoking thought, urging change, questioning the status quo, and are willing to stand up and be

\footnotetext{
${ }^{6} \mathrm{Glen}$ Martin and Gary McIntosh, The Issachar Factor (Nashville, TN: Broadman \& Holman, 1993), 75.
} 
counted. It was the fact that a number of young people were urging change which first brought them to the attention of the leadership in the Oerlikon SDA Church. In looking for such people it is, however, important to avoid the slick talkers who create a lot of hot air, but do not actually do anything.

\section{Complementary Aptitudes .}

For a leadership team to achieve change there must be a distribution of leadership styles among the leaders. George Barna has identified four leadership styles which are vital to make the team effective. These he has called "complementary aptitudes."7 Without them a team will fail to achieve its goals.

First, there must be a Directing Leader on the team. Leaders who can direct, "excel at conveying a compelling vision... They have a life-long track record of success based upon their reliance on intuition. They do not shrink from the tough calls." The directing leader is usually the most prominent leader who serves as the engine of progress. Like Nehemiah or Paul they are usually the leader of leaders. Without such visionary leadership the team tends to stagnate.

Second, there must be a Strategic Leader on the team. Strategic Leaders like to create "the practical means of converting the vision into action." Whereas the directing leader is often bored by details the strategic leader is thorough. His particular task is to

\footnotetext{
${ }^{7}$ Barna, The Power of Team Leadership, 99.

${ }^{8}$ Ibid., 101-102.

${ }^{9}$ Ibid., 103.
} 
break the vision into practical steps which can be taken up by the followers. A team which does not break its vision into practical steps will leave the church feeling overwhelmed. Often the church will resist the vision as a result. Moses' father-in-law, Jethro, was probably a strategic leader.

Third, there must be a Team-Building Leader. "Team-building leaders love people. ... They love to organize people around a common cause." 10 They can encourage and motivate individuals to feel positive about the goals of the leadership team, and to motivate them to participate in the vision which the team has cast. This leader helps unite the church around the vision and the individual steps which the leadership team proposes to take. It is possible that Barnabas, who encouraged John Mark to take a second attempt at mission work, was a team-building leader.

Fourth, a team needs an Operational Leader. Operational leaders assume managerial tasks. They "devise systems that make things run smoothly. They may also serve as a hub through which ... activity is coordinated to ensure that there are no loose ends." "Il The operational leader ensures that the technical questions people ask concerning the change process are taken care of.

Many leadership teams fail because the talents of the leaders are too similar. A team made up of visionary leaders, for example will often have a great time envisioning their dreams for the future, but without the abilities of a strategic leader, the vision will often be too overwhelming for the intended recipients to attempt. Alternatively, the

\footnotetext{
${ }^{10}$ Ibid., 104-105.

${ }^{11}$ Ibid., 106.
} 
absence of a team-building leader will often mean that the vision is inadequately communicated; the absence of an operational leader can mean that the vision is presented in such a chaotic manner that its intended recipients lose patience with the leadership. It is the complementary qualities of these leaders which achieve the ultimate goal of the team: that of changing lives.

Ellen White adds a word of warning to those who shy away from including those on a team who think differently from themselves: "No confederacy should be formed with unbelievers, neither should you call together a certain chosen number who think as you do, and who will say Amen to all that you propose, while others are excluded, who you think will not be in harmony. I was shown that there was great danger of doing this." 12

There are measurement tests which help evaluate the aptitudes of team members. George Barna's leadership test "Christian Leadership Profile" (www.barna.org) is one such yardstick. Another is the online assessment available from Ministry Insights International (www.leadingfromyourstrengths.com).

\section{Dynamics of a Strategic Leadership Team}

The Team Leader and the Team Vision

A vision is "a compelling mental portrait of a preferable future." ${ }^{13}$ Envisioning means articulating a clear picture of what you want to achieve in order to lead people

\footnotetext{
${ }^{12}$ Ellen G. White, Life Sketches (Mountain View, CA: Pacific Press, 1943), 321.

${ }^{13}$ Barna, The Power of Team Leadership, 43.
} 
toward that goal. The "vision inspires people ... attracts people to a cause ... builds community ... [and] sustains [them]. ${ }^{.14}$

Usually the vision is the brainchild of one leader who attracts others to gather around it. In a local church setting this leader is often the senior pastor but does not have to be.

There are a number of questions which leaders need to ask themselves as they form the vision: "Have you yielded yourself fully enough to God? Have you asked God to unveil his vision for your life, or are you asking him to bless a plan that you've already come up with? Have you fasted? Have you prayed? Have you been quiet and waited on God in solitude? Have you cleaned up sinful patterns in your life? ... Have you read avidly? ... Have you visited a variety of ministries around the world? . . Receiving a vision from God ... involves the quiet, internal work [of prayer] ... and also the energetic, external work of exploring and experimenting." 15

Because the vision comes from God it will not necessarily be congenial to ourselves. The leader's first question is not, What do I want to do? but rather, Am I willing to be led and used by him? A true vision is not what brings us most pleasure but what "brings Him [God] the greatest delight." 16

In order to articulate a vision the team leader will work through four basic

${ }^{14}$ Ibid., 40.

${ }^{15}$ Hybels, 38.

${ }^{16}$ Barna, The Power of Team Leadership, 50. 
questions with the leadership team: What is our mission? "Who are we? ... Where are we going? ... How will we get there?"17

The first question which the Strategic Leadership Team must ask, "What is our mission?" is fundamental because the way it is answered affects everything the church does. Another way of posing this question is to ask: "What are we supposed to be doing?" Almost all Adventist churches pay lip service to the Great Commission (Matt 28:19-20) and the messages of the three angels (Rev 14:6-12), but many provide little evidence that they take these divine directives as seriously as they could. A Strategic Leadership Team in an Adventist church will, as a result of their study of these and similar passages of Scripture emphasize the dual role of the church in calling the world to the worship of the creator and fostering mature discipleship among believers.

In order to answer the second question (Who are we?) the team will analyze the present characteristics and situation of the church. A useful tool is the SWOT technique in which Strengths, $W$ eaknesses, $O$ pportunities, and $T$ hreats are listed. It will use the strengths and opportunities of the church in order to reach out to the neighborhood and win people for Christ and his church. It will consider weaknesses and threats as challenges to be overcome.

Third, the Strategic Leadership Team will envision a direction for the church. This is the step which will probably take the most time, prayer, thought, and faith to formulate. It will involve the work of analyzing the local community which it is trying to reach. It will attempt to match the strengths of the church with the needs of the

\footnotetext{
${ }^{17}$ Malphurs, Advanced Strategic Planning, 25.
} 
community. The result will be the vision which the team is determined to realize in the future.

The final question (How do we get there?) helps determine the strategy which the team will develop as a result of its prayers and planning. This step breaks the vision down into the individual parts necessary in order to realize the vision.

The leadership team will thus take time to write its vision out exhaustively. It will also take time to distill it into a phrase of twenty-five words or so in order to communicate it effectively to others. This process will be described in more detail in chapter 4 .

This vision underpins the work of the Strategic Leadership Team. The activities of the team are built on a vision as a house is built on a foundation. The vision forms the parameters within which the Strategic Leadership Team focuses its efforts. The vision will define the goals of the team, focus its efforts, and motivate its activities. It will break it down into measurable specific goals, strategies (general approach), and tactics (specific actions).

The leadership team must form the vision with care. If the vision is flawed or the individual members are not in agreement with the vision the team will be crippled. It is thus the prayerful definition of the vision as well as its complete support by team members which decides how effective the Strategic Leadership Team will be.

Teams should be able to articulate their own vision statement. This will not only help them to remain focused on their primary tasks but also to ask the right questions about team progress, such as: Are we accomplishing our mission? Why? Why not? Where do we go from here? 
The vision of the Strategic Leadership Team will also form the "umbrella" under which all other ministry teams in the church will congregate. Each sub-team will form its own vision statement using the vision of the church leadership as its guide. "If the defining vision of a congregation is 'to glorify God by making disciples and meeting needs,' then clearly every affiliate ministry team ... [will ask itself the questions], 'What are we doing to 'make disciples'?' 'What are the needs of the people we are serving, and how can we address them?",18

Forming its vision does not, however, bring the work of the Strategic Leadership Team to a close. The team must also take on the responsibility of communicating the vision, implementing it, monitoring it, correcting, and redefining it. It is an ongoing process which will ultimately be passed on to the next generation of leaders.

\section{Team-Building Activities}

A team is more than a committee with another name. The aim of this section is to describe the elements which help to create a team out of a group of individuals.

\section{The Team Covenant}

Soon after a team comes together it needs to form a covenant. A covenant forms the "by-laws" of the group. Having a written covenant increases the commitment of team members to the aims of the team. Signing a covenant, or even merely giving verbal assent to a covenant, is far more binding than agreeing to serve on a team in which there is no formal agreement governing the relationships within the team.

\footnotetext{
${ }^{18} \mathrm{Ott}, 52$.
} 
Many question the value of a covenant. They see themselves as responsible individuals who act on what they say and find the necessity of assent to a formal agreement superfluous, demeaning even. A covenant seems to imply either a lack of trust on the part of the team towards the individuals within it or to cast doubt on their maturity. This objection needs to be taken seriously. Why is a covenant important for a Strategic Leadership Team?

First, covenants were initiated by God. He entered into covenant with his leaders in order to structure his relationships with them (Gen 12:1-3). For the same reason he also entered into covenant with communities (Deut 5:1-3). Covenants are not merely human means of structuring relationships; they are modeled by God.

Second, the purpose of a covenant is to bring order to the interaction of individuals. Christians who work on a team as a result of their commitment to God form a community which is far more intimate than a club or a corporate board. They will be more akin to a family. Greater intimacy also brings a greater possibility for injury and hurt. Just as God has instituted a covenant to govern the family relationship (marriage) so it is both biblical and sensible to insist on a covenant to govern the relationships within a Strategic Leadership Team.

Covenants can vary from a few simple statements to being highly structured documents. ${ }^{19}$ Every team covenant should include an insistence on the small group elements inherent in team work. Because the committee structure is so deeply engrained in the Adventist consciousness this insistence is absolutely necessary, otherwise the

\footnotetext{
${ }^{19}$ Ibid.; appendix 1.
} 
Strategic Leadership Team will degenerate into being just another committee. A further necessary covenantal clause is the insistence of confidentiality within the group. This clause needs to be qualified, however. A team member who breaks the law of the land, or remains unrepentant concerning the law of God, has forfeited the trust of the team and cannot expect the team to retain confidentiality.

\section{Small-Group Activities}

Strategic Leadership Teams can expect to meet over a number of months in order to develop a strategy. Aubrey Malphurs suggests that he would allow a Strategic Leadership Team "from nine months to a year to work through the initial envisioning. ... During this time, the team meets every third or at the most fourth week. ${ }^{20}$ Therefore the team can initially expect to meet at least once a month over a period of nine months to a year in order to complete this first phase of its work which could require patience by some. They will then continue to meet regularly in order to implement its goals.

As part of its time together the Strategic Leadership Team should deliberately take time for small-group activities at the beginning of its meeting. One of the most important aims of these activities is to engender friendships among individual members. Often the team will take time to eat together and take team-time to share some of their lives with their fellow team members. At the very least, a team will schedule half an hour at the beginning of each meeting for such small-group activities. Stanley Ott suggests the "Word-Share-Prayer" ${ }^{21}$ formula of small groups as a necessary part of team work.

\footnotetext{
${ }^{20}$ Malphurs, Advanced Strategic Planning, 37.

${ }^{21} \mathrm{Ott}, 60$.
} 


\section{Word-Share-Prayer}

One of the simplest ways to describe a ministry team is as the marriage of small group life and task-based committee function. In team meetings the small group elements of team work should always be done before the task-based functions. These small group elements usually take up about half an hour of the meeting. Ott describes a basic pattern: "We spent ten minutes engaging in substantive conversation about a brief passage of Scripture, fifteen minutes sharing the blessings and concerns of our lives with each other, and five minutes praying for one another by name. ${ }^{, 22}$ A useful tool to enhance the depth of contact between team members is the prayer partnership. Team members can use biblical prayers to pray for one another, such as Eph 1:15-19; Col 1:9-12 and Ps 100. As they pray these prayers they can insert the names of the prayer partner in the appropriate places.

Jesus used the word-share-prayer principle in training his disciples: he instructed his disciples (word), as a friend he walked and talked with them (fellowship), and he prayed with them. We never read of him leading a committee. Somehow the picture of Jesus leading a committee of disciples is amusing - it is certainly alien to our picture of his ministry. It is not necessary to work differently than he did.

The fellowship of a team encourages members to move forward with passion and enthusiasm. As a result, a team which also practices the word-share-prayer principle usually generates more ideas. While the tendency of established committees such as church boards is usually to safeguard the status quo, leadership teams are far more

\footnotetext{
${ }^{22}$ Ibid., 100.
} 
willing to try new ideas in obedience to the voice of God. Often the courage which it takes to do so arises out of the insights gained in their time with God together.

Some will ask if the additional elements of discipleship and friendship are necessary in teamwork. They are, after all, time-consuming. Long-term, however, a team which apparently uses less time for its task-based assignments and more time in smallgroup activities will, in fact, achieve more.

This was certainly true of the Strategic Leadership Team in the Oerlikon SDA Church. The bonding which occurred among its members as a result of friendship and social activities was responsible for the free interchange of ideas as the group met to discuss the needs of the church. The Team did not, for example, feel a need to implement formal brainstorming sessions. The group was used to expressing its ideas without fear of criticism or disparagement. The trust which friendship had created was the key to their willingness to make suggestions without fear of being considered outlandish.

\section{Trust and Vulnerability}

A willingness to share is one of the keys to teamwork. Ideas flourish as human beings share not just facts but ideas, feelings, and aspirations. Yet sharing feelings in a group situation is one of the most difficult things to do. Many find it embarrassing.

Sharing assumes that the team members trust each other and are willing to some extent to be vulnerable in each other's presence. Gareth Icenogle has identified five levels of group sharing: ${ }^{23}$

\footnotetext{
${ }^{23}$ See Icenogle, 76.
} 
Level 1: Cliché Conversation. At this level there is no willingness to share with others. Conversation avoids engagement. People do little more than recognize that other persons are present.

Level 2: Reporting the facts. This level includes minimal sharing and reporting of objective knowledge and raw data without the addition of personal reflection or feeling.

Level 3: Sharing ideas and opinions. This represents the start of sharing personal information because specific opinions are unique to each individual. It involves risktaking because other people in the group have the potential to reject one's opinions. Rejection can impact personal security or self-esteem. Much human communication ends at this level. This is the deepest level to which much education, business, and committee work goes.

Level 4: Sharing feelings, values, and emotions. At this level human beings share a part of their individuality which is hidden to society in general. When sharing at this level people's senses are highly alert to the manner in which the group receives their words. They are usually looking for others' feelings in response to their own. Their values are exposed because feelings show true values. Exposure at this level usually takes time, and necessitates trust. Rejection can hurt a person's sense of security.

Level 5: Confessional sharing. This represents the peak of communication. These feelings are spoken of only in very safe relationships. Some experiences and feelings may never be shared with another human being. Many people might not even admit their feelings to themselves. On the contrary, at this level many feelings are repressed. Under normal circumstances people will release these feelings only to gracious, compassionate, and merciful listeners, or maybe, only to God. People allow themselves to become 
vulnerable at this level because rejection at this stage of sharing has the potential to severely damage both their sense of security and self-esteem.

Leadership teams do not necessarily aim for level 5 sharing; however, the "small group" nature of the team means that level 4 sharing takes place among its members. The quality of leadership, the length of time the members serve together, and other factors will exert an influence on the level at which a team communicates. Members of leadership teams will, additionally, commit themselves to integrity in their relationships in order to promote a level of trust which is conducive to the levels of intimacy necessary for their work.

The need for trust within leadership teams has a number of implications. First, much communication consists of body language; teams need to face each other in order for true communication to be facilitated. The team should meet in a situation where they can form a circle rather than in a classroom where they will sit in rows.

Second, a team should not become too large. A team of more than about six members means that groups often form within the team.

Third, the role of the group leader is pivotal in determining the level at which the group communicates. One of the leader's key aims is to promote interpersonal relationships, model trust, and within reason, vulnerability as a means of furthering fellowship and discipleship. The leader's example will have an effect on the growth of the team in this respect. It is a great help when the group leader has had training or experience in small group leadership.

Fourth, social interaction helps the Team to "gel." A weekend retreat or a day spent on an outing together can be of great value in promoting trust among members of a 
team. The members of the Strategic Leadership Team in the Oerlikon SDA Church bonded as a result of social time spent together.

Robert Maddux in his book Team Building has included a number of statements on building trust from individuals who learned team building techniques. "To build trust it is essential to have clearly and consistently administered goals that contain employee input. Employees must perceive their managers as open, fair, honest and willing to listen. Managers must be decisive and stand by their decisions in difficult situations," wrote one individual. ${ }^{24}$ Another wrote: "I define trust as an assured reliance on the character, ability, and strength or truth of someone or something. Trust is built in a work group by promoting open communication, providing fair leadership and supervising with sensitivity." 25 These are goals at which the team leader must aim.

Fourth, in aiming for trust and vulnerability the team needs to be aware of extremes in this respect. Some members may be tempted to perform a type of "striptease of the soul," laying bare intimate feelings and attitudes in an attempt to become the center of attention. Confessional sharing is done with the aim of repentance and not in order to become an object of interest. In such situations the group leader will need to have a quiet word with the member who feels the need to persistently lay bare intimate feelings.

To summarize: Trust is an important aspect of team work. When trust is generated the team will be encouraged to share at a level which promotes friendship and genuine

\footnotetext{
${ }^{24}$ Robert B. Maddux, Team Building (London; Kogan Page Ltd, 1998), 61.

${ }^{25}$ Ibid., 62.
} 
discipleship. The example of the group leader is crucial in promoting trust and its corresponding attitude of vulnerability.

\section{Toxicity within the Team}

Any functioning team holds potential for a great deal of creativity within itself. It is also capable of creating conflict. Conflict does not have to be feared. It can be a means of generating positive contributions if handled wisely and providing it does not get out of control. This section describes a few typical causes for toxicity within the team and suggests a number of solutions.

\section{Sources of Conflict}

Robert Maddux has identified four main reasons for conflict within a team: First, differences in needs, objectives, and values; second, different expectations of outcomes of decisions, either favorable or unfavorable; third, an unwillingness to work through issues, collaborate, or compromise; fourth, differences in perceiving motives, words, actions, and situations ${ }^{26}$ Any or all of these differences will often result in power struggles within a team.

A Strategic Leadership Team which starts to fight at its first meeting has probably been badly chosen. "New groups hardly ever fight. They are not yet in touch with their differences. New groups have not built up negative patterns which wear out their members ... [this takes] one to two years. ${ }^{, 27}$ It usually takes a year or so for the

$$
\begin{aligned}
& { }^{26} \text { Ibid., } 55 . \\
& { }^{27} \text { Ibid., } 36 .
\end{aligned}
$$


"honeymoon" time of teamwork to pass. By then the excitement of innovation has usually begun to turn into the difficulty of promoting deep change within the church. This is a critical point in the life-cycle of a Strategic Leadership Team. It is often at this point that power struggles over the direction which the team should take will become apparent. Often differences of opinion festering in the background will assume greater proportions as individuals disagree on policy. Conflict may result.

Conflict within Christian leadership teams is not unknown. There are, after all, prominent precedents: "A dispute also arose among them, which of them was to be regarded as the greatest" (Luke 22:24). Power struggles stretch the emotional and spiritual maturity of the primary leader. Just as Jesus defused the power struggles of his disciples at the last supper by his example of service, so the example of the primary leader of a Strategic Leadership Team will be critical in avoiding the disintegration of the modern-day team. The primary leader must demonstrate fairness, discipline, humility, and courage in all his dealings.

\section{Approaches to Conflict Resolution}

In addition to listing sources of conflict Maddux has suggested "five basic approaches to conflict resolution., ${ }^{28}$ The first he calls avoidance. This approach simply ignores the problem and hopes it will go away. The second he terms accommodating. This includes cooperation of one or more team members even at the expense of personal goals. The third is the win/lose approach. This is aggressive and confrontational. Team members who adopt this approach are determined to win the argument at any cost. The

\footnotetext{
${ }^{28}$ Ibid., 55-56.
} 
fourth approach Maddux calls compromising. This, too is aggressive, striving to achieve its aims but also recognizes that it is important for all parties to maintain good relationships. The aggression of this approach thus has its limits. It recognizes that there is more than one good way to do anything. The fifth and final approach Maddux terms problem-solving. This is a win/win approach. Team members who adopt this approach are assertive yet they maintain a high respect for mutual support. They seek mutually beneficial solutions.

Of these, the first four are typical of human behavior but usually not productive. The final approach is the one which will promote the long-term success of the team. Sometimes the team will have to adopt approach four if imaginative solutions (approach five) cannot be found. It is up to the team leader to implement a problem-solving approach which aims at the best possible outcome for the team and its goals.

\section{Differences in Personal Styles}

Sometimes power struggles are a result of differences in personal styles. "Conflict on your team is predictable based on the respective styles of the individuals that make up your team (not to mention our sin nature!). Knowing the default setting of each person on your team can enable you to identify predictable conflict and reduce or eliminate it." ${ }^{29} \mathrm{By}$ the "default setting" John Trent means the strengths and limitations of our personal style. When the primary leader sees that predictable conflict arises he can suggest taking a personality evaluation test. 56.

${ }^{29}$ John Trent, Leading from Your Strengths (Nashville, TN: Broadman \& Holman, 1999), 


\section{The DISC Profile}

DISC is an acronym for the four main personality types found in human beings: Dominance, Influence, Steadiness, and Conscientiousness. Most human beings are a mix of types but usually one type tends to stand out among the others. The DISC test can help individuals understand their own personality type.

"DISC was originally a group of psychological tests developed by John Geier and based on the 1928 work of psychologist ... William Moulton Marston Ph.D. (1893 1947) to examine the behavior of individuals in their environment or within a specific situation. DISC looks at behavioral styles and behavioral preferences." ${ }^{30}$

The test helps people understand the intensity of their particular personality type. People who rate as highly conscientious but have little of the other three main personality types in their make-up will be known as "high Cs." This means that the factor conscientiousness in their personality is intense.

Once a person knows his personality type he is introduced to the strengths and weaknesses of that type. A high " $D$," for example, describes people who tend to be dominant, direct, decisive, and demanding in their interaction with others. A high "I" describes people who influence and inspire others and who are interested in people rather than objects or processes. A high "S" describes people who are steady, stable, secure, and sympathetic. The " $\mathrm{C}$ "' personality is correct, conscientious, and compliant.

\footnotetext{
30“"DISC assessment," Wikipedia, http://en.wikipedia.org/wiki/DISC_assessment (accessed 11 March 2008).
} 
There are a number of publications which make the DISC test available, some of which have been translated into a number of languages. ${ }^{31}$ Most of these publications are relatively cheap to purchase, and easy to understand.

\section{Advantages of the DISC Profile}

The insights gained by taking the DISC, or a similar personality test, bring a number of advantages to team work. First, while some team members feel that the team would function well without them, having an awareness of their own strengths gives them confidence in their own value to the team. The self-assurance gained by taking the personality test encourages team members to stay on the team and contribute, even though they may not be dominant members.

Second, an awareness of personality helps reduce irritation and friction within the team. When team members understand the strengths and also the weaknesses of their personalities they learn to be patient with the strengths and weaknesses of others. For example, a team members with a high " $D$ " factor, recognizing that the high " $\mathrm{S}$ " on the team needs time to adjust to the consequences of a major decision, will be prepared to wait a while before demanding decisive action from him or her. While irritation with different personality types will always occur, the harmonious working of the team will be greatly increased by the understanding of the strengths and weaknesses of personality types.

${ }^{31}$ Recommended is The Keys for Positive Relationships published by the Institute for Motivational Living. This has been translated into many of the major European languages. Also recommended is John Trent, Leading from Your Strengths, which makes an online personality test available at extra cost. 
Third, recognition of personality types helps the team to blend its strengths. Members of the team who like to look at the "big picture" are supported by those who like to do detailed study of a situation and vice versa. Collectively, the team can be strong in all areas of its work.

Fourth, an understanding of personality types help team members understand how to communicate more effectively with others on the team. Human beings prefer to receive information in a manner congenial to their own personalities. Dominant types prefer to receive information which is "clear, specific, brief, and to the point." $" 32$ They like to "discuss a problem in [the] light of how it will show results ... but have difficulty when you ramble or repeat yourself ... [and] make generalizations.... [Steady types] High S's love it when you ... give them time to adjust to changes ... but have difficulty when you are pushy or overly aggressive." ${ }^{33}$ When the communicator is aware of how another member of the team likes to receive information he can adapt his communicative style to suit that person. As a result the decision-making becomes better and the team more effective.

\section{Limits of Conflict Resolution}

A leader must be patient with team members, particularly those who exhibit "high intensity" characteristics on the DISC profile. But if the leader recognizes that the immaturity of an individual on the team outweighs the advantages of his strengths he

${ }^{32}$ Trent, 84.

${ }^{33}$ IML DISC, The Keys for Positive Relationships (New Castle, PA: The Institute for Motivational Living, 1998-2003), 53. 
must be willing to ask that person to step down from his responsibilities. This will occur before the point when the weaknesses of a team member jeopardize the team to the extent that it starts to disintegrate.

\section{Avoidance of Conflict}

Just as conflict can cause a team to disintegrate, so avoidance of conflict can cause a team to lose its effectiveness. Toxicity within the team is not always indicated by disagreement. Sometimes it can be evidenced by a reluctance to disagree. As this is usually expressed by silence on certain topics this form of toxicity can be hard to identify. After two years of working together a number of issues surfaced among the members of the Strategic Leadership Team of the Oerlikon SDA Church which needed to be dealt with. These issues concerned team strategy rather than personality, yet nevertheless, for fear of affecting friendships some of the members preferred to remain silent on these issues. This avoidance of conflict was understandable but it also resulted in a reduction in the effectiveness of the Team. One of the ways of overcoming avoidance is by instituting regular evaluation.

\section{Evaluation and Coaching}

Evaluation is biblical. Chapters two and three of the book of Revelation are devoted to evaluating seven key churches. Further, the apostle Paul encouraged the believers in Corinth to "examine themselves" before partaking of communion ( 1 Cor 11:28). The Bible encourages evaluation both at the church and individual level.

There are a number of reasons why a Strategic Leadership Team needs to evaluate its work and progress. First, "what we choose to evaluate sends a message to our people. 
It says this [ministry] is important. ${ }^{\prime 34}$ (For many of the insights on evaluation in this section I am indebted to Aubrey Malphurs, Advanced Strategic Planning, 295-308.) It signals to all those involved that they are expected to do their best. Second, it affirms those who are doing well. Third, it helps uncover blind spots and areas which need correction. Fourth, evaluation promotes positive change.

For evaluation to take place there must be a series of questions asked concerning the ministry, the task, or the person. Often a good starting point for evaluation is the job description or strategic objectives. These can be used to frame the questions used for evaluation. The team will ask such questions as: Did we achieve our goals? If, not, why not? What can we do to achieve them in the course of the next evaluation period?

Then, there must be people willing to do the evaluation. An honest team can evaluate itself, but it is always wise to ask the intended recipients of the ministry to perform evaluation as well. This is often especially enlightening if the intended recipients of the ministry are not members of the church.

Finally, evaluation of regular ministries must be done on a regular basis; once a year is a good starting point, depending on the type of ministry involved. Aubrey Malphurs gives a number of sample evaluations in appendix $\mathrm{L}$ of his book Advanced Strategic Planning. ${ }^{35}$

A Strategic Leadership Team must set goals and evaluate its performance according to those goals. But in addition to asking questions about its task it will also ask

\footnotetext{
${ }^{34}$ Malphurs, Advanced Strategic Planning, 297-298.

${ }^{35}$ Ibid., 357.
} 
questions about itself. It will find a way of assessing the contentedness of its team members. A member who is unhappy with the progress or the goals of the team will soon leave. For this reason a team leader should create an evaluation form based on the team dynamics. Leaders can ask questions such as: Can you still subscribe to the common vision? Are there aspects of the team covenant which bother you? Do you find the time spent in small group activities profitable? Do you think that the members of the team trust each other sufficiently for the work of leadership? Do you sense an area of conflict which needs to be dealt with? The answers to these questions will usually reveal whether the team has "gelled" or whether there are areas of discontent which need to be dealt with.

Evaluation provides opportunities for coaching, particularly if evaluation shows dissatisfaction with the team or its goals on the part of its members. Coaching is a key ingredient in team building. The role of coaching is to help team members "grow and adjust to change. ${ }^{" 36}$ Coaching is usually done by the team leader on an individual basis, in which the coach and the team-member have time to reflect by themselves. Usually this is done formally in the form of a structured interview.

Robert Logan and Sherilyn Carlton suggest five steps for successful coaching: First, relate (establish a relationship with the person being coached by listening carefully); second, reflect (discover and explore key issues with the person being coached. These issues may be areas of concern or dissatisfaction); third, refocus (determine priorities and encourage the person being coached to take action steps);

\footnotetext{
${ }^{36}$ Maddux, 69.
} 
fourth, resource (encourage the person being coached to find resources which provide support and encouragement for the direction he or she wishes to take); fifth, review (aid the person being coached to evaluate progress and, if necessary to revise plans). ${ }^{37}$

It is not always possible or desirable for the team leader to enter into a formal coaching relationship with team members. It suggests a mentor/mentee relationship which not all find congenial. However, the team leader who recognizes dissatisfaction with the team on the part of its members can coach informally by using Logan and Carlton's five steps in personal visits with individual team members.

\section{Summary}

Because the committee structure is so deeply entrenched within the Adventist psyche it is useful in summary to enumerate the advantages of the Strategic Leadership Team structure over a standard leadership committee such as the church board. It is also helpful to enumerate the advantages of the team structure over leadership by individuals.

\section{Advantages of Teams over Committees}

The following advantages have been enumerated by Stanley Ott: ${ }^{38}$

The team not only does a job but also builds fellowship. ${ }^{39}$ God designed us for koinonia (1 John 1:3), for fellowship. He has called us not just to fulfill tasks but "to love one another." Teams develop genuine friendship by taking time together for meals and

\footnotetext{
${ }^{37}$ Robert E. Logan and Sherilyn Carlton, Coaching 101: Discover the Power of Coaching (St. Charles, IL: ChurchSmart Resources, 2003), 29.

${ }^{38} \mathrm{Ott}, 9-10$.

${ }^{39}$ Ibid., 9.
} 
free time activities. Further, taking part in the ups and downs of the spiritual life of team members automatically fosters a caring, praying mentality for ones' fellow team members. As a result of relationship, individuals grow in faith and commitment to Jesus and his church.

The team not only does its job but also fosters discipleship. ${ }^{40} \mathrm{~A}$ church board will rarely spend time supporting the spiritual life of those on the committee itself. Team members, by contrast, take time in discussion and prayer to nurture each other. Through practices such as Bible study, prayer, and service, together the members of the team grow in their closeness and obedience to Jesus.

Strategic Leadership Teams are a divine construct. A most impressive biblical image is that of Moses sitting down with his leadership team of elders to a meal on a mountain in the Sinai Peninsula (Exod 24:9-11). The elders had just been privileged to receive one of the most sublime divine encounters ever given to humankind after the fall. Both the revelation of God's glory and the chance to talk about it among themselves at their meal directly afterwards would have had the effect of fostering a common vision among the elders of Israel. By appearing in his glory, God unified them and turned them into a team. It is legitimate to say that the team concept is not just biblical but was fostered by God himself.

Similarly, many years later Jesus sat down by a fire on the shores of the Lake of Galilee with the future leaders of his church and ate with them. At this meal he forgave Peter for his denial and graciously gave him a personal commission. It is not known what

$$
{ }^{40} \text { Ibid., } 10 .
$$


else was talked about at that meeting but the time Jesus spent with his disciples after their shattering experience of the crucifixion certainly helped bond them into a team. Just as the Father fostered leadership teams among his Old Testament people, so Jesus fostered leadership teams among the leadership of his New Testament church.

These two examples show that biblical leadership teams were more than committees with another name. They combined a task-based ministry with a small-group type of ministry to their own members. Teams bear similarities to committees in that they fulfill certain tasks but they add another vital component: they are also relationship and discipleship oriented. This results in enormous advantages both for the individuals concerned and the church as a whole. ${ }^{41}$ It should therefore not surprise us to recognize that team leadership is a divine construct.

\section{Advantages of Teams over Individual Leadership}

In the past, evangelistic leadership was usually provided by the church pastor. Typically the pastor would organize a series of meetings, hold them, and then conduct the necessary Bible studies to lead the contacts to baptism. Assistance came from a team of willing lay members. There were, and still are, many variations on this theme. But in the main the function of the lay members of the team would be largely as "helpers" rather than co-leaders in evangelism. Because this pattern is still current in the minds of many Adventists it is useful to enumerate the advantages of Strategic Leadership Teams over individual leadership. The following advantages have also been enumerated by Stanley Ott.

$$
{ }^{41} \text { Ibid., } 16 .
$$


The team not only does its job but also does it in a more well-rounded, balanced manner. ${ }^{42}$ One person alone leading the evangelistic thrust of the church will not bring the same amount of energy, love, vision, and follow-through that an entire team can offer. Ministry teams gain their power as a result of "the confluence of purpose-driven ministry and small-group life." ${ }^{43}$ As a result of their relationships with other team members, individuals gain the confidence to express their ideas. A lone leader can never achieve the mix of gifts, talents, and experience that a team has at its disposal.

The team takes the pressure off the senior pastor to perform. There are few "super pastors." In an age in which quality is highly-prized the limitations of average leaders can put them under great stress. The team, however, releases the individual leader from the pressure of congregational expectations. First, team work means that the pastor is not alone responsible for the quality of church work. Second, a team will combine the gifts of a number of individuals to provide a quality of leadership which cannot be met by any one individual. "The purpose of a team is to make the strengths of each person effective and his or her weaknesses irrelevant. ${ }^{, 44}$ George Barna discovered that pastors who led through teams "enjoy their vocation more, stay at their churches longer, and are less prone to burn-out" than pastors who lead alone. ${ }^{45}$

Teamwork results in more innovation. "As our culture becomes more

\footnotetext{
${ }^{42}$ Ibid., 14.

${ }^{43}$ Ibid., 9.

${ }^{44}$ Barna, The Power of Team Leadership, 76.

${ }^{45}$ Ibid., 82.
} 
complicated, and people's attention and energy is diverted from the things of God, we will need more creative responses to engage people in spiritual development and ministry. A great idea is a great idea, whether it comes from one person or from a team. But the evidence indicates that the push-pull dynamic that occurs among a group of individuals with a shared commitment is likely to outdistance anything that the loneranger leader conceives. ${ }^{" 46}$ Traditionally the pastor, usually working without a leadership team, has been the engine which drives evangelistic activity. Pastors have mostly clung to what they have been taught or what they feel comfortable doing. Their lack of creativity, however, has resulted in a severe reduction of evangelistic success. Leadership teams can help bring back creativity to all forms of church ministry and particularly evangelism.

Teams reduce the ability of certain individual leaders to control and dictate. While it is hardly flattering to say so, it is nevertheless a fact that there is usually a leader who exhibits these characteristics in every church. If this is the church pastor it is often difficult to restrain this tendency to dominate church decisions and such a person is the least likely to promote team leadership with its emphasis on joint decision-making. However, in congregations where the team process has become part of the church culture dictatorial leaders are forced to behave more democratically. Their ability to create an oppressive atmosphere within the church is reduced.

The team not only does its job but also helps "develop and deploy new leaders. "47 In the same way that Moses integrated Joshua into his leadership team so the Strategic

$$
\begin{aligned}
& { }^{46} \text { Ibid., } 79 . \\
& { }^{47} \mathrm{Ott}, 11 .
\end{aligned}
$$


Leadership Teams recognize that people learn to swim by getting in the water, not by merely reading books about the butterfly stroke. They thus integrate younger members with potential into their work. Lone leaders have fewer opportunities to train the next generation of leadership.

The team not only does its job but also provides continuity of leadership. Writing about the development of his Sunday school team, Stanley Ott makes the following comment, "Only after learning the pattern of ministry-team thinking did I discover that ... teams not only permitted the teaching load to be shared but also developed a cadre of teachers who provided a continuity of leadership. ${ }^{.48}$ When lone leaders retire from their positions then the church has the thankless task of finding replacements. The replacements then have the structures built up by the previous leaders dumped on them, whether they suit them or not. Ministering in a team means that the next generation of leaders is being trained on the job.

Teamwork is more biblical. Although Christian ministry started as team-based, "by the end of the second century, church organization and ministry were increasingly centered on pastors and other key leaders. The core biblical concept of the priesthood of all believers ... was superseded by the notion that church leaders did the ministry and the people received it." ${ }^{49}$

The teaching of the priesthood of all believers and that of the gifts of the Spirit are two sides of one coin. Both negate the notion of clergy-dependence. Further, the teaching

$$
\begin{aligned}
& { }^{48} \text { Ibid., } 13 . \\
& { }^{49} \text { Ibid., } 14 .
\end{aligned}
$$


that the Holy Spirit gives gifts to all believers emphasizes the necessity of interdependence which lies at the heart of team work. It is not God's plan for leaders to work independently. 


\section{CHAPTER 4}

\section{STRATEGIC PLANNING BY STRATEGIC LEADERSHIP TEAMS}

Chapter 3 described both the process of setting up a Strategic Leadership Team and the dynamics to be expected in such teams. This chapter describes the core activities of Strategic Leadership Teams: the process of strategic planning and the implementation of the plan.

\section{Confirming the Mission}

Nehemiah (Neh 2:3-5), Moses (Exod 3:10), Paul (Acts 22:21), and other biblical leaders had a clear understanding of their mission. Their God-given mission provided the guidelines for their decisions and thus shaped the future course of their ministry. Similarly, the Adventist Church has been given a mission which provides guidelines for the decisions of its leaders and shapes the future of the church.

\section{Defining the Mission}

Mission is defined by the question: What are we supposed to be doing? The mission of the Adventist Church is summarized in Matt 28:19.20 and Rev 14:6-12. Both of these passages of scripture should form the basis for the mission of every local SDA congregation. 
A church can be divided over its mission because individuals do not share the mission of the church as a whole. It can be ineffective because its mission is more aspirational than actual. But without an awareness of what the church is supposed to do, very little will be done.

\section{Developing a Mission Statement}

Many SDA Churches have lost sight of their mission. This presents the Strategic Leadership Team with an ideal opportunity to develop one. The first step in developing a mission statement is to ask what the church is supposed to do. Second, the answer to that question must be written down in a short clear statement, bearing in mind the type of people it is designed for. Aubrey Malphurs advises mission drafters to ask the question: "What words communicate best with your target group?"1 Reading the mission statements of other churches, easily found on the internet, often helps a team develop its own. The Navigators, for example, have the following statement: "Our mission is to know Christ and make Him known." ${ }^{2}$ Third, the Strategic Leadership Team needs to abide by its mission statement in forming its vision and strategy. Once the mission statement is completed it becomes the guiding aim of the church; the Strategic Leadership Team must not let itself be sidetracked by distractions.

\footnotetext{
'Malphurs, Advanced Strategic Planning, 133.

${ }^{2}$ Ibid., 140.
} 


\section{Casting a Vision}

\section{Vision Defined}

"Mission describes why an organization exists; vision describes what that organization will do about its mission in the future. ${ }^{\prime 3}$ In defining its vision the members of the Strategic Leadership Team will ask how to put its mission into practice in their locality. They will make the question, What is it that God wants us to do? specific, by asking: What does God want us to do here and now?

As a help to answering this question it is useful to ask further questions, such as: Whom are we trying to reach? How are we going to accomplish this? Where is our geographic target? What are the results we anticipate? The answers to these questions will form the basis of the vision statement.

The vision statement should not just make the mission of the local church specific to its surroundings; ideally it should also be designed to inspire its intended recipients. To read Deut 8:7-10 is an example of a vision statement which is both specific and inspirational:

For the LORD your God is bringing you into a good land, a land of brooks of water, of fountains and springs, flowing forth in valleys and hills, a land of wheat and barley, of vines and fig trees and pomegranates, a land of olive trees and honey, a land in which you will eat bread without scarcity, in which you will lack nothing, a land whose stones are iron, and out of whose hills you can dig copper. And you shall eat and be full, and you shall bless the LORD your God for the good land he has given you.

This is a vision statement which not only communicated God's vision for Israel but did so in inspirational language.

\footnotetext{
${ }^{3}$ Kenneth O. Gangel, Team Leadership in Christian Ministry (Chicago, IL: Moody Press, 1997), 277.
} 
A vision is "a clear, challenging picture of the future of the ministry, as you believe that it can and must be." Eduard Schmidt summarizes vision: "Vision is the destination —it suggests . . . a desired future reality. . . . Vision is an image - it conveys a picture of the future that God has painted across your heart and in your mind.... Vision is simple and compelling... [ [It] captures the heart and mind in such a way that people are willing to commit their resources of time, talent, and treasure to make it a reality.... Vision also has the quality of uniqueness-it hints at what makes something special."

Vision is simple, challenging, and focuses on the task which the local church aims to accomplish. At the same time it fires the imagination and motivates. It describes the impact truth can have on our communities if believers are willing to "let their light shine before men."

The Importance of Vision

Because a vision gives people a sense of purpose it provides energy to do the task at hand. People are motivated by a clear vision. "The right vision creates meaning in people's lives, providing them with a cause and giving them a sense of divine purpose. They are a part of something bigger than themselves." ${ }^{\circ}$ They realize that they are not merely pew-warmers or useful for their finances but co-workers in a cause. A vision encourages faith-motivated risk-taking and self-sacrifice.

\footnotetext{
${ }^{4}$ Malphurs, Advanced Strategic Planning, 151.

${ }^{5}$ Eduard E. Schmidt, Class notes, Intervention for Renewal, Andrews University, 2006.

${ }^{6}$ Malphurs, Advanced Strategic Planning, 147.
} 
Nehemiah sacrificed a highly influential position in order to rebuild the walls of Jerusalem (Neh 2:5). His vision sustained him in times of crisis and motivated others to support the task financially (Neh 4:21-23). A credible vision has the same effect today.

\section{Developing a Vision Statement}

Putting a vision into words takes a lot of hard work. First, "set a good foundation by reading and studying God's plan for your life and the church." $"$ This could include meditating with the leadership team on the book of Ephesians or Christian Service ${ }^{8}$ or Recovering an Adventist Approach to Life and the Mission of the Local Church ${ }^{9}$ or some similar challenging, inspirational literature and asking questions such as: "What is our biblical calling? What is God willing to do through us? What key concepts or values define us? What blockages to exercising my [our] evangelistic ministry can I [we] identify? What are some of the sacrifices we need to make in order for God to work through us to reach lost people?"10

This exercise must be bathed in prayer. As individuals and as a team the request that God will reveal his vision for the church must be one of our most important prayer requests. "A wise investor turns spare time into prayer time." for God's voice means that the leader's vision will be influenced by and will not merely

${ }^{7}$ Schmidt, 14.

${ }^{8}$ White, Christian Service.

${ }^{9}$ Russell C. Burrill, Recovering an Adventist Approach to Life and the Mission of the Local Church (Fallbrook, CA: Hart Research Center, 1996).

${ }^{10}$ Schmidt, 15.

${ }^{11}$ Martin and McIntosh, 15. 
be the product of his or her own limited imagination. The ideas which flow as leaders pray for God's guidance should be journaled.

Second, the needs of the local community should be assessed. "What type of financial, theological, sociological climate surrounds you?"12 This can be gauged by using local government statistics or by conducting a simple survey. Church members can go from door to door stating simply that they are from the local church, asking what needs there are in the community and how a church can possibly help meet those needs. Aubrey Malphurs has a sample survey which can be used. ${ }^{13} \mathrm{~A}$ further method of understanding the area surrounding the church is to speak with local community leaders. With time, a number of key needs will emerge.

Third, listen to the congregation. It is worthwhile listening carefully to what church members have to say because people support what they feel they own. On a Sabbath afternoon or evening the leadership team can meet with the church in order to evaluate its own strengths and weaknesses. The techniques of brainstorming and storyboarding can be useful. As the congregation lists its strengths and weaknesses, patterns emerge. The emerging patterns help the leadership team in its choice of evangelistic emphasis and in creating its vision for the future.

Fourth, aided by meditation, prayer, and data collection the team will meet to express the vision in words. The team will start by asking, "What is God's vision for our church?" By using brainstorming and storyboarding techniques it will start writing its

\footnotetext{
${ }^{12}$ Gangel, 279.

${ }^{13}$ Malphurs, Advanced Strategic Planning, 173-194.
} 
vision down. "After a season of prayer bring the group together and dream aloud, recording on a board the ideas and visions that emerged. ... There is a messiness to the process: vision creation is usually a process of two steps forward and one step back. . . Both analytical thinking and a lot of dreaming are essential throughout the activity." 14 As part of this process the leadership team will attempt to match the strengths of the church to the needs of the community and use the strengths of the church to reach out to others. As a result of this exercise the first draft of a written vision will start to emerge.

Fifth, the vision statement should be read by as many people as possible before it is given its final form. A wise leadership team will allow for as much feedback from the church as possible. It is vital that the leaders of any ministries which may be affected by the vision be part of the consultation process. A good leadership team will also try to get feedback from non-members who may well be targets of the vision. Before the vision statement is put into its final form it will probably be revised a number of times.

There are a number of questions which will help craft the vision statement: "Could I . . . 'see' it when I heard it? Is it God-sized? Is it clear and simple? Is it compelling and inviting? Did it speak to me? Is the long-range view appropriate for the intended beneficiaries? Does it encourage faith? Does it motivate me to get involved? Does it expand God's kingdom?"15 Asking these questions which hark back to the definition of a vision statement will help craft the vision statement.

\footnotetext{
${ }^{14}$ Schmidt, 16.

${ }^{15}$ Ibid., 16-17.
} 


\section{Tools for Creativity}

The process of forming a vision statement is greatly assisted by the use of two tools for creativity known as brainstorming and storyboarding. These two useful tools help communicate, organize, and harmonize the thought processes of a group of people. Because they are particularly useful in the development of a vision, and almost indispensable in the process of strategic planning, it is important to deal with them at this point.

\section{Brainstorming}

Brainstorming is a well-known technique for spawning ideas. It is important that the group be aware of the basic rules of brainstorming. These include restraint in criticism of other people's ideas and a willingness to curb long-windedness. The ideas generated must be capable of being written down in a few words.

An idea which can add both fun and creativity to brainstorming is that of allowing each member of the team to award himself a small candy for each idea produced. Criticisms of other people's ideas and prolixity result in the loss of a candy (the leader needs to buy the candy in advance. Suggestion: getting a team member to make brownies also goes down well, especially if the team gets to eat the leftovers at the end of its planning session!)

The team leader should also think carefully about the basic question which brainstorming is designed to answer in advance. Irrelevant questions waste time. When used in connection with the attempt to find the strong and weak points of the church, useful questions can be found in the SWOT acronym. The leader may suggest that the 
team simply answer the questions: What are the Strengths, Weaknesses, Opportunities, and Threats which our church has/faces? The team members should write their responses to the SWOT questions on post-it notes. They are allowed a certain amount of time for this. Usually, as brainstorming is fast-paced, they will have an initial time limit of five to ten minutes or so.

Ideas generated can also be written on a large flip-chart. When written on post-it notes, however the participants should confine themselves to one idea per note. In this way the process can be taken a step further and developed into the storyboarding technique.

\section{Storyboarding}

Aubrey Malphurs refers to storyboarding as "compression planning," it condenses planning processes into a short period of time. Large sheets of paper (flipchart sized sheets) are hung around the room and are categorized into the main topics under discussion. If the group is discussing the SWOT questions then there needs to be four sheets of paper on which these questions are written hanging in the room. The participants stick the ideas generated by brainstorming and which they have written onto post-it notes onto these sheets of paper according to topic. They stick them neatly one below another in order to facilitate the next step.

For the next step each participant is given six small colored stickers approximately a quarter of an inch in diameter, three red, two blue, and one yellow. They are then requested to place three red stickers next to the post-it note which in their

\footnotetext{
${ }^{16}$ Malphurs, Advanced Strategic Planning, 42.
} 
opinion contains the most important idea of the brainstorming session, two blue stickers next to the second most important idea, and one yellow sticker next to the third most important idea. In this manner the ideas which the group considers to be most important are clearly marked with the largest amount of colored stickers. The priority which individuals assigned to the most popular ideas is also evident. These ideas are usually the ones which can be worked with. A variation on this theme is to allow each participant to evaluate the five most important ideas written on the paper sheets on a scale of one to ten. In this manner key ideas are evaluated according to their importance relatively quickly by the group.

\section{Communicating the Vision Statement}

A vision will die a rapid death unless it is communicated inspirationally. The vision must be communicated first and foremost by the example of leadership. The pastor and members of the Strategic Leadership Team must be highly visible when activities relating to the vision are implemented. "The leader's example is critical to communicating the vision. If the leader does not live the dream, no one else will. People watch what leaders do as well as what they say."17

Additionally, the sermon is a highly important means of communicating the vision. However, not just the "what" but also the "how" is important in information transfer. Sermons which merely inform, or worse, instruct people in the course of action that they "must" pursue will not elicit the same response as sermons which inspire. Antoine de Saint-Exupery once said that "if you want to build a ship don't herd people

\footnotetext{
${ }^{17}$ Ibid., 160.
} 
together to collect wood and don't assign them tasks and work, but rather teach them to long for the endless immensity of the sea." ${ }^{18}$ Inspirational stories of other churches which achieved similar visions or motivational stories of people who in some ways contributed to achieving a vision have an appeal which simple information or directives will never achieve. The information that the organ fund is in need of $\$ 10,000$ will not have the same appeal as a story about a little girl who broke open her piggy bank in order to support the project.

There are other avenues of communication which can be used such as the bulletin, skits and drama, flyers, and video presentations. It is important that the vision is repeated in as many ways as possible. Repetition is a vital key to conviction.

\section{Planning by Setting Objectives}

Once the vision has been defined and cast into a statement the process of specific planning can begin. This process is termed "Planning by Objectives" and its aim is to translate the vision into a chronologically ordered series of objectives.

The Importance of Planning by Objectives

Some people do not plan at all. They reason that God knows everything and human beings should simply rely on him to intervene at appropriate times. "A hidden assumption of this approach is that proper spirituality cuts out the need for human

\footnotetext{
${ }^{18}$ Antoine de Saint-Exupery Quotes, http://www.brainyquote.com/quiotes/authors/a/ antoine_de_saintexupery.html (accessed 17 June 2008).
} 
forethought." ${ }^{19}$ Others plan as if God had no part in their plans and no power to intervene in human processes. Both positions ignore biblical reality. God expects human beings both to use their divinely-guided common sense in planning and also to reckon with the intervention of the Holy Spirit. Nehemiah prayed for the restoration of Jerusalem but also laid plans to bring it about (Neh $1: 3-4 ; 2: 4-8)$.

Planning by objectives also provides a measuring gauge which helps a church transform itself. Specific, measurable objectives which are intended to be achieved within a certain time-frame provide a means for evaluating progress. A church may wish to increase the size of its children's Sabbath School. The members may thus make it their objective to have ten children in Sabbath School every Sabbath punctually by the end of the coming year. An evaluation of the progress of this goal at the end of the year will show whether the leaders have achieved it or not. As a result of their specificity and measurability, planning objectives can help a church transform itself.

Further, planning by objectives invests time and does not merely spend it. "Some people don't take fifteen minutes to read a map before starting on a trip through unfamiliar territory, so they end up losing forty-five minutes when they get lost."20 Planning objectives is an outlay of time and energy which ultimately avoids wasting both. Finally, planning by objectives helps turn a vision into reality. Objectives turn the vision into the specific steps necessary by which the vision can be realized. Without specific objectives very little will usually be achieved.

${ }^{19}$ Edward R. Dayton and David A. Fraser, Planning Strategies for World Evangelization (Grand Rapids, MI: Eerdmans, 1990), 15.

${ }^{20}$ Gangel, 290. 


\section{Principles of Planning by Objectives}

When planning, certain principles should be kept in mind. First, planning is cyclically based on evaluation. "Poor evaluation leads to poor planning."21 The habit of evaluation is a great aid to planning because it helps set realistic goals, which are based on clearly visible results. Evaluation also helps correct plans which have been unfruitful. A team which can evaluate its plans is in a position to plan better in the future.

Second, "planning should allow for maximum participation; . . planning is not the vision of a single person." ${ }^{.22}$ It is a corporate activity because we are "part of a fellowship that is well described as a body." ${ }^{23}$ Strategic planning is executed by a relatively small Strategic Leadership Team, but it will draw as many members of the church into the consultation process as possible.

Third, planning cannot determine the future. A leadership team makes decisions which shape and affect the future; it can create structures which motivate people to take certain actions but they cannot force them to do so. People have the freedom to exercise choice; they also are subject to ill-health, adverse circumstances, and unforeseeable future events. A wise planning team will remember that even "the best laid plans of mice and men often go awry." ${ }^{24}$ The planning team will thus meet regularly to revise and reshape plans that are not working.

\footnotetext{
${ }^{21}$ Ibid., 291.

${ }^{22}$ Ibid., 292.

${ }^{23}$ Dayton and Fraser, 294.

${ }^{24}$ Robert Burns, Selected Poems: To a Mouse (Ware, Hertfordshire: Wordsworth Edition Limited, 1994), 109.
} 
Fourth, planning increases in specificity as the event draws near. Long range planning of anything over approximately five years can at best be described as "forecasting. ... The further we project into the future the less reliable our forecasts become." 25 However, the closer an event comes the more detailed the planning needs to be so that its realization is successful.

Fifth, there is no "silver bullet" which eliminates strategic planning. "The single revolutionary paradigm shift ... is at best highly elusive or just a plain myth. . . Most leaders get discouraged when they try the one fail safe thing that is guaranteed to bring about a revolutionary breakthrough and then after all the commotion see little results.,26 Leaders must be prepared to do the hard work of planning.

\section{Process of Planning by Objectives}

There are three questions which strategic planners ask: Where are we now? Where do we want to be in X years' time? How will we get from here to there? The answer to the first two questions will have been largely answered as the Strategic Leadership Team determined its mission and vision. Strategic planners answer the third question by determining the specific, measurable goals anchored within a time frame, which will help move the church from its present position to the one desired. They also determine the individual steps necessary in order to reach those goals. Because these steps are specific, measurable, and linked to a specific time frame they can be evaluated:

${ }^{25}$ Dayton and Fraser, 302.

${ }^{26}$ Schmidt, 20. 
"unless we can create statements to which we can answer yes or no, we do not have specific action steps."27

For an action step to be put into practice a number of questions need to be resolved: What will be accomplished? Who is responsible for implementing it? When will it be done by? How do we create awareness and support for it? Do we need to include training events in order to accomplish the step? How will the step be financed? How will the leaders be recognized or recompensed for their efforts? These are questions the leadership team will need to answer as it decides on its action steps.

Initial steps on the way to the goal will often be small; however, they create the "victories that propel change forward" ${ }^{28}$ and help create a sense of confidence which will lead to larger steps. These steps should be few but done "with excellence." 29 They can include redecoration of the church hall or initiating a training program for teachers of the Sabbath School lesson aimed at improving the quality of Sabbath School discussion groups. Such steps will often characterize the first year of the strategic plan.

The impetus and confidence gained by initial "wins" will help propel the changes necessary in the second year of vision realization. The second year will be characterized by new ministries or, perhaps, by significant changes to existing ministries. These also need to be planned step by step. This is the time to "realign old ministries and resources to the ... vision and have a funeral service for activities and ministries that are uselessly

\footnotetext{
${ }^{27}$ Gangel, 281.

${ }^{28}$ Schmidt, 20.

${ }^{29}$ Ibid., 22.
} 
consuming valuable resources. ${ }^{, 30}$ The planning of these steps demands considerably more credibility of leadership because they demand a greater amount of time and effort on the part of those ministry leaders implementing them.

In the third year the process of realizing the vision will require a repetition of the same planning process done in the first two years. It will consist of small steps aimed at reaching the vision goal, just as before. In addition, however, it will need to include the hard work of reaffirming the vision. People get tired of change and desire the comfort of regular habits. This attitude will often be apparent both in the leadership team as well as in the church. At this stage the determination of the leadership is a decisive factor in keeping the vision alive. Leaders will need to spend much time in praying that they do not enter into the temptation of becoming complacent. In addition, leaders will face unexpected challenges as Satan sees that God's kingdom is gaining ground.

Perseverance, both in communication and pushing change forward is the order of the day.

As time passes successful ministries grow from small beginnings. The fourth year is often a time in which larger steps can be taken. This is the time to "ask yourself, what are the insurmountable obstacles and giants we must face?"31

Evaluation must remain a constant part of this process. Often a ministry or an organizational step gets stuck. "Every plan will suffer from gaps." 32 If a ministry is not producing the expected results it will be necessary for the Strategic Leadership Team to

$$
\begin{aligned}
& { }^{30} \text { Ibid. } \\
& { }^{31} \text { Ibid., } 23 . \\
& { }^{32} \text { Ibid., } 24 .
\end{aligned}
$$


evaluate the reason why. It can then brainstorm for intermediate steps in order to lead to the desired result. Evaluation is an essential aid in recognizing the right course to adopt in order to keep the vision on target.

As a result of evaluation the Strategic Leadership Team will sometimes recognize that it has attempted more than is realistic: "People are feeling pressured, the process is moving too fast and transitions are not being addressed, subsequently people will resist everything that comes along." ${ }^{, 33}$ It will be necessary to take a step or two back in order to go forward. This is not a major tragedy; it is part of the process. It is far better to take a step or two back than to lose the vision completely.

\section{Common Mistakes in Planning}

Kenneth Gangel has listed a number of common pitfalls made in the planning process. He includes, first, a "failure to make the tough decisions. ${ }^{~}{ }^{34}$ Some tough decisions may be financial, others will affect personnel. Failure to make them will bog down the planning process; cause the vision to lose momentum, and the church to lose confidence in leadership. A second common pitfall is the "failure to keep constituents informed. ${ }^{35}$ Lack of information creates uncertainty and uncertainty results in resistance. The progress of the planning team must be well-communicated. A third pitfall is simple, old-fashioned "timidity" which Gangel equates with a lack of vision. He recommends

${ }^{33}$ Ibid., 25.

${ }^{34}$ Gangel, 303 .

${ }^{35}$ Ibid. 
that leaders make the organizational vision their top priority focusing on it in prayer and thought.

\section{Putting the Plan into Action}

At some stage planners have to take the plunge and start implementing the plan. Bear in mind "there is no exactly right time or ideal conditions [to do this].,"36.

The Team Leader and Implementation of the Plan

Implementation of the strategic plan depends on the primary leader more than on anyone else. The primary leader is usually the senior pastor. Malphurs suggests that the leader should first write a "stop doing" list in order to create time for implementation. Then he should write down the goals which he wishes to achieve and keep them where he can see them. These exercises are designed to motivate the leader and help him focus his time and energy on the realization of the vision.

Second, the leader must plan his time wisely.

One of the new discoveries in modern sports psychology is that performance comes in waves. We cannot be at our best all the time... . Pastors have observed this phenomenon for years. Beginning about Tuesday, pastors begin to pray, plan, study, and prepare to speak on Sunday. Monday, typically becomes a day to let down. This 'periodization' often leads to a positive feeling on Sunday and a depressed feeling on Monday. ... Some methods for controlling your wave are to keep regular sleep patterns, exercise on a regular time schedule, set goals, and maintain a positive mind set. ... [In addition pastors must take] control of . . . time for meetings, confrontations, counseling, speaking, and study. ${ }^{37}$

\footnotetext{
${ }^{36}$ Malphurs, Advanced Strategic Planning, 281.

${ }^{37}$ Martin and McIntosh, 74-75.
} 
Third, leaders must remember that while they will want to keep the church happy they are also change agents and will create discontent among some. This should drive them to their knees in order to ask for divine wisdom. They will pray for discernment in order to distinguish between immediate necessary change and changes which can be accomplished later. They will also pray for a spirit of generosity in dealing with people for whom change is disturbing.

Fourth, leaders should recognize that despite the fact that they are working for God and have prayed for divine leading they will make mistakes. They must be willing to learn from them. Ellen White once wrote to a pastor: "If it is apparent that you have made mistakes, it is your privilege to turn these failures into victories by avoiding the same in the future." 38

Fifth, leaders must be patient. Most leaders will be impatient to see the vision become a reality. They must acknowledge however, that change will not happen straight away. They must channel their impatience and persevere. "Less can be accomplished in a year than you think but more can be accomplished in five years than you think." ${ }^{39}$ Leaders should also remember that they are shepherds, who lead their sheep. Impatient shepherds who run too far ahead of their sheep will one day realize that they are no longer following him. In a marathon race an individual runner is motivated by the pace of the runner just ahead of him —not by the pace of the race leaders he cannot see. The leader of change must be patient. 1948), 495.

${ }^{38}$ Ellen G. White, Testimonies for the Church, Vol. 3 (Mountain View, CA: Pacific Press, ${ }^{39}$ Martin and McIntosh, 66. 
Sixth, the leader must practice the virtues of courage and gratitude. Jesus demonstrated both qualities, thus reminding us that these are divine attributes. The leader will spend time daily in prayer and Bible study. In communion with God, the leader will receive the gift of courage in abundance from the Father who gives every good gift to his children. As a result the leader will be moved to praise and thank God for his goodness. Courage and gratitude will keep the leader from becoming discouraged.

Communicating the Plan

John Kotter suggests that "managers undercommunicate." $"$ The most important principle of communicating vision and plans is repetition. Repetition of the message should take as many forms as possible. Martin and McIntosh say, "As a rule of thumb, plan on communicating your vision a minimum of five different ways every year until the vision is reached.... Interview people who illustrate the vision from the pulpit. . . Make banners to hang in the church auditorium.... Personally visit every member of your church to share your vision and answer questions about it. Take church leaders to seminars and workshops which will help them catch the spirit of the vision. . . Update the congregation on the progress toward the vision at least quarterly."

In addition, communication should be kept simple. John Kotter suggests using images which convey pictures. "Use metaphors, analogies, examples,"42 he advises and 85.

${ }^{40}$ John P. Kotter, Leading Change (Boston, MA: Harvard Business School Press, 1996),

${ }^{41}$ Martin and McIntosh, 65-66.

${ }^{42}$ Kotter, 91. 
gives the following example in which Version \# 1 shows the manner in which the vision should not be communicated: "Version \# 1: We need to retain the advantages of economies of great scale and yet become much less bureaucratic and slow in decision making in order to help ourselves retain and win customers in a very competitive and tough business environment. Version \# 2: We are going to throw out some of the rule books and give employees more discretion to do the right thing for our customers." ${ }^{43}$ Finally, the aim of communication is not merely to inform but also to persuade. "Pericles, ruler of ancient Greece, had a realistic view of his own gifts: 'When Pericles speaks, they say, "How well he speaks." When Demosthenes speaks, they say, "Let us march." ","44 Communicating a vision means being able to influence people to march together in the same direction. The greatest influence in this respect is the personal example of the leader.

\section{Establishing Urgency}

Because change brings uncertainty in its train people become complacent, or worse, change-resistant. John Kotter has identified nine sources of complacency.

\footnotetext{
${ }^{43}$ Ibid., 92 .

${ }^{44}$ Martin and McIntosh, 71.
} 


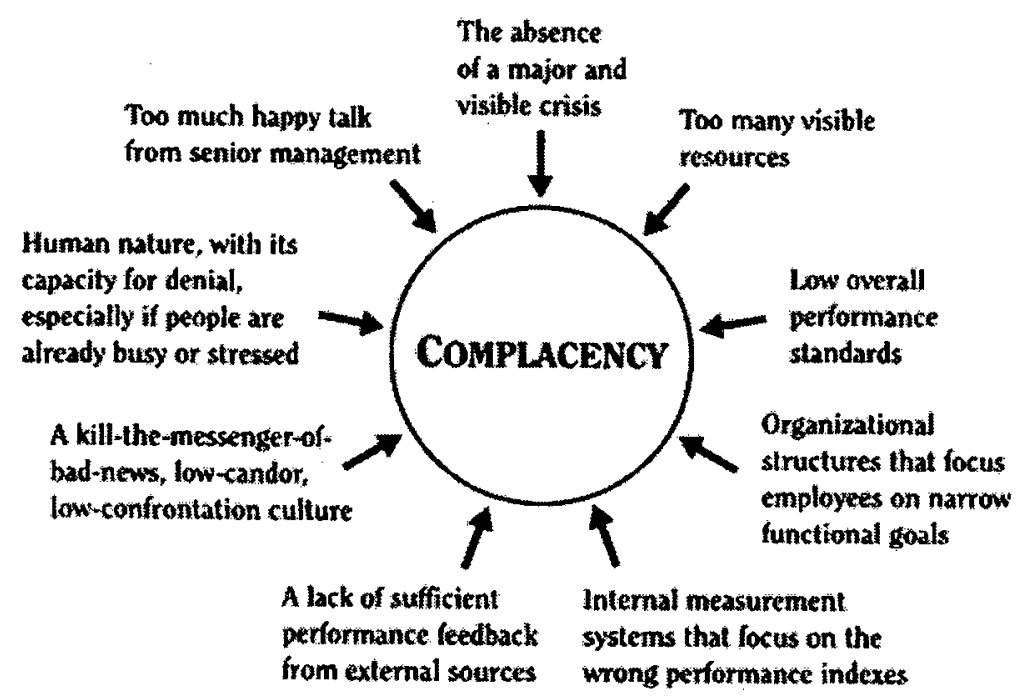

Figure 1. Sources of Complacency. Source: Kotter, Leading Change, 40.

Kotter suggests that "a good rule of thumb in a major change effort is: Never underestimate the magnitude of the forces that reinforce complacency and that help maintain the status quo."

"Creating a strong sense of urgency often demands bold or even risky actions that we normally associate with good leadership... . [These are usually initiated by new leaders because long-time executives] fear that they will be blamed for creating the very problems they spotlight. ${ }^{, 46}$

There are a number of ways to raise the urgency level. One of the most effective ways is to create a crisis by exposing weaknesses. This will not be difficult in most indigenous SDA churches in Europe and North America as an examination of the

\footnotetext{
${ }^{45}$ Kotter, 42.

${ }^{46}$ Ibid., 43.
} 
membership growth, the average age, or church finances will often show enough cause for concern. In addition, communicating the life-cycle of organizations to be found in Russell Burrill's book Waking the Dead ${ }^{47}$ will often help increase the realization that action is necessary.

A further method of creating urgency is to encourage evaluation of church ministries and activities by the group the ministry is trying to reach. If the ministry is aimed at the community then feedback forms can be developed which help the ministry evaluate its performance. Similarly, feedback forms for all the church ministries, including the Sabbath school and sermon hour can be handed out to members. When people express legitimate dissatisfaction their comments can be communicated in appropriate ways (an inappropriate way would be to embarrass a ministry leader by exposing his weaknesses to the whole church). Such comments will often help people realize that there needs to be change.

One of the best ways of creating urgency is to paint a vision of what the church or the ministry could be. This can be done best by showing what others have done. Hearing of other's success creates a longing for something better. A leader who can present a vision inspirationally will not only create a sense of dissatisfaction with the present but will motivate people to make changes.

The Strategic Leadership Team will encourage the prayer groups in a church to pray that the church will sense the urgency of the times in which we live and will act accordingly. In Rev 14:7 God sent a message to his remnant reminding them that "the

\footnotetext{
${ }^{47}$ Russell C. Burrill, Waking the Dead (Hagerstown, MD: Review and Herald, 2004), 31.
} 
hour of his judgment has come." Through this message God has created a sense of urgency among all who believe these words. If there are no prayer groups praying for God's leading at this time in earth's history then the first priority of the leadership team is to foster such prayer. God answers the prayers of his church when "two or three are gathered together" (Matt 18:19), and more than any other method, the united prayers of God's people will overcome complacency and create a sense of urgency which will result in building his Kingdom.

\section{Generating Short-Term Wins}

Karl Weick describes a short-term win as "a concrete, complete, implemented outcome of moderate importance. ${ }^{48}$ Characteristics of short-term wins include high visibility and unequivocality: large numbers of people see that the vision is working and even detractors have to admit that the vision is producing desirable results.

The role of short-term wins is to provide evidence that the sacrifices are worth it. But they have other benefits as well. They also help to build morale and motivation among members of the church. In the process they help to undermine the cynics, making it difficult for them to block the change process; they also help turn "neutrals into supporters, [and] reluctant supporters into active helpers. ${ }^{.49}$

Examples of short-term wins can include fixing the leaky roof, redecorating the church, holding a baptism. In communicating these small wins the leadership team should

\footnotetext{
${ }^{48}$ Karl E. Weick, "Small Wins: Redefining the Scale of Social Problems," American Psychologist 39, no. 1 (1984): 40-49; quoted in Schmidt, Class notes, 20.

${ }^{49}$ Kotter, 123.
} 
intentionally show that they are part of the overall vision. Such short-term wins make people proud of their church again and help propel the church to the next step in the change process.

Short-term wins should be celebrated in order to raise awareness of the desirability of change and also to provide motivation for it. The celebration can be a small or large event, it can include a public acknowledgement of the contribution of a major player or the chance for a key donor to give a testimony; it could include a special "birthday cake" at a potluck for key leaders. Celebrating events not only raise awareness but provide motivation for further steps.

\section{Building on Strengths}

As the strategic plan is implemented it will become apparent that certain ministries are becoming more productive than others. The church Pathfinder group, for example may start expanding by attracting a number of children from the neighborhood. Recognizing this fact, the Strategic Leadership Team will wish to build on this success. It will meet with the leaders and ask how it can support the efforts of the Pathfinder leadership. Usually it will be able to do so by increasing financial support or giving the Pathfinder leadership more access to the communication channels of the church or a high-visibility part of a church service.

Martin and McIntosh suggest that building on their strengths was the key to the success of the German Blitzkrieg in the Second World War.

The Germans would attack across a wide front. The front line commander had a simple mission: penetrate rapidly. If he met resistance, he was to lead his men around the trouble spot until he got through. The mission of headquarters in the rear was to secure the path behind the advancing forces. A blitzkrieg [sic] focuses on 
opportunities instead of problems. To reinforce your strengths spend time, money and energy supporting what works for you. ${ }^{50}$

\section{Evaluating the Plan}

The Purpose of Evaluation

Evaluation is biblical. Paul encouraged healthy self-examination at a personal level (1 Cor 11:28) and Jesus clearly evaluates believers at the corporate level as Rev 2-3 show. Aubrey Malphurs suggest seven purposes for evaluation. First, evaluation prompts ministry alignment. That is, it fosters the alignment of ministry with the values, mission, vision, and strategy. Second, what gets evaluated gets done; it shows people that the church is serious about what it is doing. Third it is fair. It lets ministers or leaders know whether what they are doing is acceptable in the long-term or not. Fourth, it affirms and encourages people who are doing a good job. Fifth, it helps correct wrong or annoying tendencies. Sixth, it helps a person improve. Seventh, it promotes change. ${ }^{51}$

\section{The Process of Evaluation}

In addition, Gangel underscores the value of evaluation to the Strategic Leadership Team. Where a team makes long-term plans, evaluation helps align the strategic plan with the reality of the emerging vision. He suggests evaluating on a yearly basis. This is best represented diagrammatically: $:^{52}$

${ }^{50}$ Martin and McIntosh, 76.

${ }^{51}$ See Malphurs, Advanced Strategic Planning, chapter 14, $297 \mathrm{ff}$.

${ }^{52}$ Kennon L. Callahan, Effective Church Leadership (New York: Harper \& Row, 1990), 240; quoted in Gangel, Team Leadership in Christian Ministry, 295. 


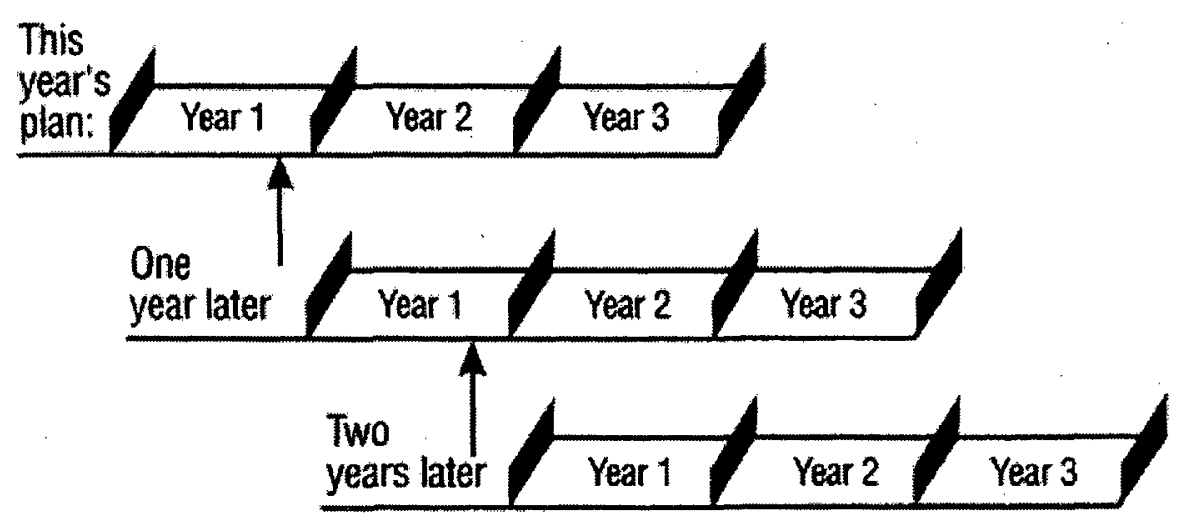

Figure 2. Evaluation on a Yearly Basis.

"It is important to put a competent leader in charge of the evaluation process. Someone has to be responsible for evaluation, or like so many other good things in ministry, it will not happen." ${ }^{, 53}$ The leadership team should choose this person. Then it should decide what will be evaluated. Often a job-description or a ministry goal is a good starting point for an evaluation form. The person or ministry which is to be evaluated should help in designing an evaluation questionnaire.

Depending on the type of ministry, an evaluation should be conducted at least once a year. Fledgling ministries need to be evaluated more often. The quarterly business meeting in SDA churches offers an excellent opportunity for evaluating the progress of the church and traditionally offers performance indicators such as membership statistics and Sabbath School attendance statistics with which to do so. In churches where the business meeting is dead it needs to be resurrected on at least a bi-annual basis. Certain ministries, such as evangelistic meetings and church services need to be evaluated

\footnotetext{
${ }^{53}$ Malphurs, Advanced Strategic Planning, 301.
} 
regularly by leadership. Ministries which are fundamental to the vision must be monitored continuously. Any serious lapses should be a subject of discussion in the monthly meetings of the Strategic Leadership Team. Aubrey Malphurs has included a good questionnaire for evaluation of the church service which is included in appendix L. ${ }^{54}$

Just as we evaluate our own efforts so evaluation must become part of church culture. At a target range "you pull the rope to bring the target back to you so you can see where your shots have landed. Having done that ... you make adjustments, fix a new target, and roll it back to its place at the end of the range.... Without evaluation we cannot make those ... corrections that take us from the beginning of the planning process to the achievement of goals. ${ }^{, 55}$

Because evaluation can be painful it is often neglected. This was one of the mistakes of the Strategic Leadership Team of the Oerlikon Church. A lack of evaluation led within a year and a half to a culture of avoidance. It became easier to talk about other things than to address the stagnation of the vision. Leadership teams must recognize that the pain of evaluation is far to be preferred than the frustration caused by the slow death of the vision.

${ }^{54}$ Ibid., 358.

${ }^{55}$ Gangel, Team Leadership in Christian Ministry, 294. 


\section{Developing the Plan}

\section{Consolidating Gains}

As the strategic steps result in change so the management of change becomes more complicated. Fledgling ministries need large amounts of support; growing ministries need decisions regarding resources; problems need solving. Often, change results in a few leaders taking on a lot of extra responsibility. In order to consolidate the gains, new leaders need to be trained who will take on lower level responsibilities. They must be selected for their belief in the vision and competency in the area of ministry.

At the same time the Strategic Leadership Team must remain focused on maintaining the clarity of the vision. The Team does this by "sustaining and advancing vision.. ${ }^{, 56}$ Sustaining the vision means continuing to support last year's program if it is achieving its goals. "Advancing vision pushes the team to consider new ways to improve its effectiveness. Advancing vision may expand the scope of the team's activities. It may increase the excellence and quality of what's already being done. ${ }^{57}$ Consolidating gains does not mean becoming complacent with achievement; it involves pushing forward into new areas. "Effective ministry-team leadership in long-established ministries holds sustaining and advancing vision in critical balance. Not 50-50, but more like 90-10giving 90 percent of the effort to sustaining what is and 10 percent to advancing what can

$$
\begin{aligned}
& { }^{56} \mathrm{Ott}, 149 . \\
& { }^{57} \text { Ibid., } 150 .
\end{aligned}
$$


be. ${ }^{, 58}$ This ensures stability but at the same time consolidates gains to avoid complacency.

In addition, consolidating gains will almost always involve restructuring. To some extent this will occur automatically as finances flow from ineffective ministries toward those which are effective. Nevertheless, at some point decisions need to be made and communicated which terminate ineffective structures and confirm the adoption of the new. In an Adventist setting this can occur when the nominating committee meets. The nominating committee may decide, for example, to place the responsibility which deacons have for visiting church members into the hands of small-group leaders. As a result the responsibility of deacons will be reduced and take on a different focus. This involves a major structural change.

\section{Anchoring Change into the Culture}

Anchoring change into an existing church culture is done by sloughing off inconsistent pieces of the old culture and developing loyalty to the new. This is the aim of the book of Hebrews. While fostering the loyalty of the messianic Jews to Messiah Jesus the writer of Hebrews at the same time showed that the ceremonial law had been superseded. A wise church leader will do this graciously and respectfully. But he will do it nevertheless or he will watch the fruit of his work disintegrate after his retirement.

In order to anchor change into a church culture leaders must attempt to change both behavior and shared values. Changing behavior alone will only produce temporary change because people usually revert to old patterns of action if their underlying values

\footnotetext{
${ }^{58}$ Ibid.
} 
or beliefs remain the same. John Kotter defines shared values as "important concerns and goals shared by most of the people in a group that tend to shape group behavior and that often persist over time even when group membership changes." ${ }^{, 59}$ Values thus reach deeper than behavioral norms. They are the convictions that shape behavior. For this reason leadership will attempt to pass on values and not just behavioral norms.

Change can be anchored into church culture when people are chosen because of their values. Their behavior is then molded by these values while they are still young in the organization. If they stay a long time both their values and their behavior become so much a part of them that they do not realize its influence. In this way change is anchored.

Clearly this process takes time. It depends initially on results because new approaches only sink into the culture once it becomes apparent that they are better. Further, it will usually involve turnover of personnel when key people will not accept change. Most of all it means ensuring that the selection of new ministry leaders is done with great care. It may even mean that the selection process, that is, the process by which the nominating committee chooses church officers needs to be managed differently.

\section{Planning Your Replacement}

A key element in anchoring change into church culture is the planning of one's replacement. Such planning ensures that new leaders are in place who will carry the vision forward when the time comes for existing leadership to move on. This is important also because existing leaders, convinced of the importance of their own vision can one day become the obstacle to renewal. Just as Moses trained Joshua so every leadership

$$
{ }^{59} \text { Ibid., } 148 .
$$


team needs to train leaders for tomorrow who will carry the torch once it is passed on.

A leadership team must be intentional about developing new leaders in order for it to happen. Most churches fall into the 'urgent demands trap'- -they expend too much energy meeting urgent demands. Bill Hybels wrote of his early experience at Willow Creek: "We rarely paused long enough to wonder about future leaders. . . Leadership development will always slip to the bottom of the agenda unless mature leaders force it to the top.... Imagine how strong a church would be if it had a deep bench of competent leaders in every area of its ministry.", 60

In order to find new leaders a team should "draw up [their] own top-five quality list ${ }^{\prime 61}$ while it is looking for future leaders and then brainstorm together, searching the membership list for church members who have those qualities. Then the team should "invest in [those] emerging leaders," 62 getting them in touch with other leaders or perhaps enabling them to attend training courses. Finally, the leadership team also needs to "entrust emerging leaders with responsibility." $"$ "In an Adventist church the Strategic Leadership Team can make suggestions to the nominating committee. In most SDA churches such suggestions would be welcome.

\section{Recognition of Accomplishments}

Workers in the cause of Jesus Christ are mostly volunteers. Very few are paid for

$$
\begin{aligned}
& { }^{60} \text { Hybels, 123-124. } \\
& { }^{61} \text { Ibid., } 131 . \\
& { }^{62} \text { Ibid. } \\
& { }^{63} \text { Ibid., } 134 .
\end{aligned}
$$


their efforts and even fewer get much credit for their achievements. It is not only fair but is a basic tenet of human relationships that workers should have recognition for their contribution. People need reassurance that their contribution is valuable. This is not only essential for a smooth-running church but is also a reflection of the character of Christ who gave credit where it was due. Of the centurion he said, "I have not found such faith in all of Israel" (Matt 8:10).

There are a number of ways of recognizing the contribution of workers and leaders. Often a simple email is sufficient in which thanks are underlined by a short account of how valuable the event was to a member of the target audience. Another way of celebrating a contribution is by enabling a contributor to give a public testimony, or by giving one yourself in which the value of the contribution is underscored. Sometimes tangible marks of contribution are prized: a gift, a certificate. Some forms of recognition are culturally appropriate while others are not. Gratitude is one of the prime motives for serving God; just as we thank him we should not forget to thank others. Gratitude motivates leaders and enables them to attempt greater things in God's service.

Showing recognition for service and accomplishment was an area of weakness in the Strategic Leadership Team of the Oerlikon SDA Church. The lack of encouragement was possibly one reason for the wane in enthusiasm which the Team felt in its second year of work. While recognition takes time and adds to the responsibilities of overworked leaders its effects should not be underestimated.

\section{Conclusion}

The Bible gives its readers relatively few insights into the thought processes of 
Jesus. Thus the reader has very little information on the methods he used to formulate his mission or vision statement. Nor do we know how Jesus went about planning. But the gospels do describe what he did. The Bible describes how he put his plans into action.

First of all the Bible depicts Jesus as a leader of superhuman ability. He was a master at communicating the plan of salvation, the most audacious plan which the universe has ever seen. Second, Scripture shows how on more than one occasion he established a sense of urgency (see Matt 10:23). Third, through signs and miracles he generated short-term wins. Fourth, he built on strengths, using the experience which the disciples had gained in running their own fishing business to help them learn how to "fish for men." Fifth, He consolidated gains in the most creative manner possible: he turned failure into success. He used the failure, and repentance of Peter, for example, to generate perseverance in this key leader. Sixth, the values he gave his disciples were so firmly anchored that these same values have survived for two thousand years. Seventh, no one could have mentored his replacement leaders better, instilling his values into their lives by his own example. Eighth, he recognized accomplishment.

Jesus thought and worked strategically, by setting, achieving, and developing objectives. 
CHAPTER 5

\section{A DESCRIPTION OF THE DEVELOPMENT OF THE STRATEGIC LEADERSHIP TEAM IN THE OERLIKON SDA CHURCH}

This chapter describes the manner in which the Strategic Leadership Team of the Oerlikon SDA Church arose. It compares its make-up and dynamics with the theoretical model described in chapter 3 . It then describes its integration into the existing structures of the church.

\section{Initial Meetings}

The Strategic Leadership Team of the Oerlikon Church was not initially formed as the result of a conscious decision. A group of five faithful and active young people between the ages of nineteen and twenty-eight became increasingly dissatisfied with the status quo within the church. In an informal gathering one Sabbath afternoon in the fall of 2005 they discussed their frustration. They recognized that the church was stagnating numerically and aging rapidly: at the time the church had declined by fifty percent in thirty years, and half of the membership was over the age of sixty (see appendices 3 and 4). What concerned them most, however, was that very few church members seemed to be concerned about this fact. They recognized that while they, as leaders of the young people's group were active evangelistically, many of the older church members appeared to show very little evangelistic zeal. In addition, they were frustrated by the fact that the 
power to change this situation lay in the hands of older members who did not appear to be doing anything about it. They were unsure how to react to this situation but decided at the end of their discussion to bring their concerns before God in prayer and to meet to talk about the situation again.

At their next meeting the hand of God became evident. The group met in the home of one of the young people whose father is both a successful businessman and a prominent member of the church. This businessman is called Max. His son, David, had already talked with him about their concerns. Now David invited his father to listen to what the group had to say about the church situation. In listening to the young people, Max both recognized the legitimacy of their frustration, and the leadership potential of the individual members of the group. From then on he became a mentor to the group. He helped direct their energies by encouraging them to state their aims and to formulate specific goals. As they followed his advice they reached a number of decisions.

To begin with, they decided to meet regularly for prayer and discussion. They also committed themselves to reading a chapter of Russell Burrill's book Waking the Dead between each meeting. Further, they decided to make an analysis of the present state of the church. Finally, they decided that evangelism must be their first priority.

Up until this point the group had met informally. Far from being a team which was intentionally initiated by a church leader in order to develop a strategy for the future, the group consisted of a loosely knit camaraderie of individuals who met to discuss their frustrations with, and dreams for the church. 


\section{Team Organization}

One of the questions with which the group struggled at the beginning of 2006 was fundamental: Was it worth attempting to reform the church or would it be easier to start separate church meetings for the younger generation? The group came to a courageous decision. Although they knew that a number of established church members would reject their ideas they decided to attempt to work with the church rather than to set up a separate structure. This decision led them to take a number of further actions.

First, they gave themselves the name Geroma, which is an acronym for the term "Church reform group" in German.

Second, one of the young people started to make notes of the meetings in order to remind each of the members what they had discussed. She became the official secretary.

Third, the group created a vision statement. It read: "We want our church to lead people to Jesus. We want to help people to grow in faith, in love towards God, and their fellow human beings." This statement was fundamental. It aimed at church growth ("we want our church to lead people to Jesus"), and stressed individual sanctification ("we want to help people to grow in faith, in love towards God, and their fellow human beings").

Fourth, they decided to make the introduction of small groups within the church their strategy by which to achieve this vision. They envisaged the small groups as having two goals. First, to nurture existing members holistically: socially, emotionally, as well as spiritually. A second goal was for the small groups to be evangelistic. The Team aimed to involve 80 percent of the church in small groups within five years. 
Fifth, the Team elected one of the young people to be its official leader. His task was to organize the agenda of the meetings and to monitor whether the individual tasks were being accomplished.

Finally, the group recognized that to achieve change they had to invite key established church leaders to join the Team. Only by working with these leaders would they have the necessary leverage within the church to make change possible. They decided to invite the two elders and the pastor to be part of the Team.

This decision represented the largest step in the formation of the Team. For the emergent group it meant having the courage to suggest to established church leaders that the group had developed better solutions for evangelism than established leadership had found so far. It also meant trusting the established leadership to be part of their future plans. In this they were greatly assisted by Max who worked as an intermediary. Before inviting the pastor and two elders onto the Team Max reassured them of the commitment of the young people on the Team to the mission of the church. He encouraged the pastor and elders to adopt an integrative rather than a defensive mindset.

At an evening meeting in which the Geroma invited the church leaders to a meal the group presented their ideas to the elders and pastor. Then they asked them what they felt about the necessity of change. They also inquired about their attitudes toward small group structures. Having received favorable answers they then invited these three leaders to their team meetings.

These organizational decisions transformed the original group of five into a team of eight members. They also changed the nature of the Team. A frustrated group of 
young people whose initial aim had been to "change the way we do church" had become a team with a vision and the potential authority to form strategy.

\section{Natural Dynamics of the Team}

Initial Frustration

The Strategic Leadership Team originally set out to reform rather than to lead. Its origins lay in frustration with the status quo. In talking about his opinion of the church before setting up the Strategic Leadership Team one of the young people said, "For quite a long time our youth group had been aware of the fact that our church was spiritually apathetic, lacking in zest. We asked ourselves: Where are the workers who are bringing in the harvest? Where are the people who have put Jesus first in their lives and are ready to give everything for him? Things cannot carry on like this." The original dynamic for the initial group discussions was discontent with the powers that be, coupled with the classic desire to "change the way we do church" rather than a determination to set up a Strategic Leadership Team.

\section{Faith in God}

Yet while discontent was originally both a unifying and motivating force within the group it was not the only force. With time, many of the dynamics essential to Leadership Teams described in chapter 3 became evident in the Team. First, the Team demonstrated a deep faith in God. All of the young people involved cared about their church because of their commitment to the Lord of the church. The result of their initial discontent was to pray for their church and particularly to pray that God would give them 
wisdom to start making changes which would lead to a new evangelistic emphasis within the church. Their faith was a vital moving dynamic within the team.

\section{A Visionary Team Leader}

A second dynamic was the presence of Max, the father of one of the young people. Highly experienced both in the business world, as well as in church leadership, Max is a visionary leader who became the group's mentor. He channeled the frustration of the young people into positive action by encouraging them to write down their reasons for discontent as well as their vision for the future. Max inspired the group to actively look for solutions rather than resigning themselves to inactivity. Thanks to Max the initial discontent with the status quo was turned into an evangelistic strategy.

\section{Friendship between Team Members}

A further dynamic was the presence of friendship within the group. The individuals involved had been the core members of the young people's group for a number of years. They both knew and trusted each other well. This friendship was a further tie that bound the group together. It also resulted in an intuitive decision to engage in team-building activities. The Geroma always ate together and took time for sharing before they engaged in strategic planning sessions. Further, the Team took a day trip into the mountains together on two separate occasions in order to promote team spirit.

\section{Willingness to Build Spiritual Foundations}

Another of the advantages of the existing friendships within the team was that the team always took time for worship after their meal together. Early on in their discussions 
they agreed to read a chapter of a book between meetings. The chapters they read formed the basis of their worship time.

The book they initially chose to read was Russell Burrill's Waking the Dead. Later they read Courageous Leadership by Bill Hybels. As part of their worship they would discuss the chapter they had read and think about its implications for the church. Then they would take time in earnest group prayer together. Only then would they turn to the minutes of the meeting. They often spent an hour and a half in the small group activities of fellowship, worship, and prayer (including the time spent eating together). This was never viewed as wasted time, however, but rather as a time in which trust was built and ideas grew. This willingness to build spiritual foundations was a further dynamic. It helped develop the Team as spiritual leaders. "My responsibilities in the Strategic Leadership Team changed me; I am not the same person as I used to be. My work for the church helped me see it in a different light," said one of the team members two years after he started working on the Strategic Leadership Team. A willingness to build spiritual foundations matured their own spiritual lives.

\section{Willingness to Accept Responsibility}

As a result of the time spent together the feeling of accountability towards the group grew. The discussions concerning the church resulted in each of the members taking on various tasks. One of the tasks involved inviting a speaker to hold a series of training events for small group leaders. This was organized by one member of the group. Another took on the task of talking with various members of the church about their willingness to lead small groups and inviting them to the training events. Another took on 
the task of organizing monthly meetings for small group leaders. Another took on the task of organizing an outing for small group participants. The secretary noted the tasks and emailed the minutes of the meetings to each member. The members of the group were very conscientious in fulfilling their tasks. The group had developed a high level of accountability.

\section{Analysis of the Team}

In this section the personality and leadership aptitudes of the individual members of the Geroma will be analyzed.

\section{Personality}

The personality of the members of the Leadership Team were analyzed by using the DISC Personality Style Profile. The personality traits summed up in the four categories of the DISC Personality Profile can be found in appendix 2 .

As expected, Max, the visionary leader of the Team, was shown by the results of the Profile to be a high "D." Although two other members of the team also exhibited the traits of a determined leader these were secondary rather than primary traits of their characters. The fact that there was only one high "D" on the team contributed to the harmonious interaction of Team personalities. At no time did the Team waste time in conflicts which were caused by the clash of temperaments.

The DISC Personality Profile also showed that at least four team members were high "Is." This also was expected as leaders tend to be made up of people with high "D" or "I" character traits. The fact that five members of the Team scored high in these 
categories confirmed the fact that the Geroma was made up of genuine leaders and not just one leader with a number of followers.

Four members of the Team showed relatively high "S" or "C" scores. Two of the members with these scores showed a tendency to doubt their own leadership capabilities. However, both clearly grew in confidence within the two years of their service on the Strategic Leadership Team and contributed decisively to the success of the Team. This result is an indicator of one of the accomplishments of the Strategic Leadership Team. The Team encouraged and empowered these younger members to take on responsibility and thus provided training in leadership. The confidence they have gained will be vital for the church in the future.

The members of the Team completed the DISC Profile after approximately two years of their work together. Two or three members of the Team did not see the point of taking the DISC Profile. They felt that the Team had been working well together and that an analysis of personality was not necessary. This was true. The advantages of the DISC analysis are in general more evident when the harmony of the Team is threatened. This was not overtly the case in the autumn of 2008 when the members of the Geroma took the DISC Personality Profile.

Further it should be mentioned that the Team did not have time to discuss the results of the DISC analysis at the time of writing. Although it is probably true that Europeans are less enthusiastic about personality analysis in general than are Americans, it is hoped that the results of the DISC Profile will be helpful in fostering communication within the Team in the future. 


\section{Leadership Aptitudes}

Chapter 3 suggested that there are at least four leadership types who should be present within a team in order for it to be effective. These included the Directing Leader who excels at conveying a compelling vision and who serves as the engine of progress; the Strategic Leader who breaks the vision into practical steps which can be taken up by the followers; the Team-Building Leader who motivates people to participate in the vision which the Team has cast; and the Operational Leader who assumes managerial tasks.

The Team spent some time one evening analyzing its own capabilities and limitations. After reading chapter 7 of Courageous Leadership by Bill Hybels the members of the team discussed their individual strengths and weaknesses. In the course of the discussion it became clear that the leadership aptitudes which Barna suggests are vital were largely present within the Team. Further, the DISC Profile confirmed the selfassessment which the members had made of their own strengths to a large extent. It was the leader with the high " $\mathrm{D}$ " profile who provided vision and leadership of the Team and who became its Directing Leader. A team member with a high "I" profile was highly effective in communicating the vision of small groups to the church. The Strategic Leader was a high "I" with the "D" style as a secondary strength.

\section{Spirituality and Team Dynamics}

More important than personality was the mature spiritual attitude which the Team members brought to their work for the church. One of the team members put it this way: "The sum of our personalities was greater than the sum of the individual parts. While our 
personalities were important for the functioning of the Team, more important was our willingness to serve God and his church." Another team member said: "We looked upon ourselves as instruments of God. We were all ready to give more than 100 percent of our time and talents in God's service. No one joined the Team as a result of the desire to gain personal glory. On the contrary our aim was to make the work of the Team successful and to give glory to God." This spiritual attitude was probably the most important dynamic within the Team.

\section{Relations within the Leadership Team}

A team is often hampered by internal dissent. This has not been the case within the Geroma. The Team was not handpicked but it could have been. There were no awkward individuals within the Team who either did not carry their weight or found objections to every idea. On the contrary, one of the team members said, "From the start we were all willing to give 150 percent of our energy. As a result of God's blessings, we saw ourselves as his instruments." There was a common understanding of service within the Team. Further, there was a willingness to spend time in working for the common vision. All of the team members considered the cause they worked for as worthy of the considerable time they invested in it.

One of the major challenges the Team had to face was a way of finding time to meet together. All of the members have more than one responsibility within the church. Virtually all members are themselves small group leaders, for example, and large portions of their free time are already taken up with church work. After initial successes two or three team members have found it difficult to balance work, family, and church 
commitments. Their willingness is not in question but their capability to sustain their contribution is limited by the free time at their disposal. This is an issue which at present is causing some frustration. In the case of the Oerlikon Strategic Leadership Team it will necessitate the signing of a covenant in the future.

\section{Growth in Self-Understanding of Team}

The group originally saw itself as an agent of reform within the church. It was for this reason that it called itself Geroma, an acronym for the German term "Church reform group." As its influence grew, however, its understanding of its function developed. About a year after its formation it began to view itself as a leadership team. This awareness was encouraged by the church pastor and elders who recognized in the Geroma a force for renewal within the church. It was also fostered by the realization that the Geroma was introducing changes which the church board had been either unable or unwilling to contemplate.

The church board at the time was made up of members who were very faithful to the teachings of the Adventist Church, and who were also highly conscientious, and organizationally efficient. They were also open to new ideas to a large extent but they were not very innovative as a group themselves. The church board did not think strategically, preferring to manage rather than lead. A further characteristic of the church board at the time was that while it was representative of the church as a whole it had a relatively high average age.

As the idea of small groups began to take hold within the church the Strategic Leadership Team realized that it had begun to introduce changes within the church which 
the church board had not done. As the group members became aware of their success they also became aware of their role. They began to think of themselves as a complementary team to the church board. Whereas the church board managed, they led. Whereas the church board concerned itself with organization, they concerned themselves with strategy. This was encouraged by the pastor and elders of the church. This awareness marked a sizeable leap in the understanding of the individuals within the Team.

The results of this change in self-understanding were evident in the church elections in summer 2007. The nominating committee for that year suggested a generational change in the church leadership. As a result the church board was reduced in size and age. One of the members of the Geroma was made an associate church elder. The activities of the Geroma had gained the trust of the church to the extent that it was partly responsible for this generational change in church leadership.

\section{Reasons for the Successful Integration of the Team into Existing Structures}

Chapter 3 noted that there are a number of models for the integration of Strategic Leadership Teams into existing Adventist Church structures. Most of these models were based on the assumption that an established church leader would call a Strategic Leadership Team into existence. The group which ultimately became the Strategic Leadership Team of the Oerlikon SDA Church clearly came into being far more spontaneously. In describing models for Strategic Leadership Teams chapter 3 mentioned the "Spontaneous Model." This model harks back to Nehemiah. Nehemiah and his team responded to a crisis without being prompted to do so by established leadership. Similarly 
the Geroma originally formed its vision without being asked to do so by the church board. In both cases there were a number of reasons why the larger body accepted the leadership of unelected "outsiders." This section describes the reasons for the successful integration of the Geroma into the leadership structures of the Oerlikon SDA Church.

\section{Relations with the Church Board}

Initial relations with the church board were marked by caution and a certain amount of suspicion. The largely youthful members of the Geroma were frustrated by the church board's lack of willingness to innovate. Some members of the church board, on the other hand, on hearing about the small group project led by the Geroma felt sidetracked: "Why weren't we consulted?" was their question. This led to some friction. Certain members of the church board demanded clarity as to the status of the Geroma.

In time, however, the church board accepted the Geroma as a legitimate structure within the church. An important factor in gaining acceptance was the early decision by the young people of the Geroma to include key church leaders in their meetings who were also church board members. In addition to using their influence on the church board to let the ideas of the Geroma develop they also set up a church business meeting in which the Geroma could openly talk to the church about its ideas and plans. This meeting provided an open forum for questions, and helped dispel fears and suspicions. As a result of the prayerful influence of these leaders the two groups worked side by side.

To this day one board member is dissatisfied with the arrangement. In addition, there are areas of responsibility which are not clear. However, there is a willingness to work together: the Geroma concerns itself with strategy and the church board with 
management. One small spin-off as a result of the work of the Geroma is that the church board has become more pro-active in leading rather than merely managing the church.

In an ideal world the church board would have recognized its limitations. It would have come to the realization that a complementary team of innovative leaders was necessary and would have taken steps to set up such a structure. Although they did not do so it is nevertheless to their credit that they were willing to accept and work with the Geroma, a Strategic Leadership Team which was made up of much younger members.

\section{Relations with the Pastor}

One of the reservations which the pastor faced when he first became aware of the emergence of the Geroma was the underlying criticism of the Geroma towards the established culture of the church. At the time the pastor was seen by the members of the Geroma to be part of that culture. The pastor was unsure just how constructive the emergent group was prepared to be.

On the other hand the emerging team experienced a certain amount of reserve in informing the pastor of their feelings. Their suggestions implied criticism of his leadership. They were fearful of rejection and concerned that rejection would bring a consequent frustration of their ideas.

This somewhat fraught situation was overcome by talking together, building understandings, and deepening the relationship with the team members. This is an important principle for self-emerging teams; trust is the key to success and it can only be established rapidly by dialogue and time spent together. 
A further hurdle, once the pastor was embraced by the Team, was his status as part of the Team. Many pastors like to assume positions of authority as a result of their position. From the start, however, it was clear that the key visionary leader on the Strategic Leadership Team was Max. Further, team organization was done by one of the young people, Pablo. Pablo was twenty-one at the time. It was evident that the pastor would have to accept that much church strategy would be directed by a team over which he had influence but which he could not control. He had to relinquish authority. Not to have done this would have meant creating toxicity within the Team and eventually killing it. This hurdle, too, was overcome by dialogue and trust. The pastor spent a number of working lunches discussing the direction of the Team with Max, its leader. The bond thus created and the agreements reached helped dispel uncertainty.

The status of the pastor on the Strategic Leadership Team is that of a member. In reality, however, his function goes beyond that of merely contributing toward strategic planning. The pastor is also a vital key to harmonious relations between the Geroma and the church board. By supporting the initiatives of the Geroma and explaining their purpose he helps avoid possible power struggles between the two groups.

The pastor also protects the Strategic Leadership Team. As an unelected body it is vulnerable to criticism. By showing his support for the Team in church board and church business meetings he can deflect criticism and encourage support for Team ideas.

\section{Conclusion}

Most of the Leadership Team models described in chapter 3 were based on the assumption that an established church leader called a leadership team into existence. 
From the description above it is evident that the Strategic Leadership Team of the Oerlikon SDA Church was not initially the result of intentionality but rather the response to a felt need. However, this does not mean that intentionality was completely lacking. Intentionality was important in transforming the group from a collection of individuals which felt itself as outsiders into a leadership team. The following factors were key components in this transformation.

First, the individual members of the team never questioned the fact that they were a team. None of the individuals was ever concerned with personal acclaim or attempted to dominate the others. From the outset the individual members desired to work together and were willing to accept collective responsibility. In this they intuitively accepted the divine method of leadership by team as evidenced by Moses and the seventy elders or Paul and his "magnificent seven."

Second, the team was united by a common vision. Although the Team initially was discontented with the church, these feelings were not the result of personal immaturity but were based on the desire to foster the mission of the church. Once given encouragement, the group was quick to articulate its aims. Just as Nehemiah's team was united around a common vision, so the Geroma united around the vision of winning souls for Christ.

Third, the group was made up of individuals of good character who had given their lives to Christ. Just as the early disciples chose "men of good repute, full of the Spirit and of wisdom" (Acts 6:3) as deacons, so the team was made up of young people who were dedicated, faithful, and committed to the cause of Jesus and his church. 
Fourth, the group automatically practiced community. At the time, they were probably not aware of the incident in Exod 24 in which the elders of Israel were privileged to catch a glimpse of God's glory and afterwards were able to discuss the experience over a meal together. They were almost certainly not aware of the importance to a team which time for socializing and celebrating achievements brings. But they took time to eat, worship, and share together anyway. Community was one of the keys to their success as a team.

Fifth, a leader emerged who brought intentionality to the group. Max helped the group shape its aims, its structure, and its methods. While never attempting to dominate, he became the prima inter pares. Just as Luke described Peter as spokesman of the disciples on the day of Pentecost (Acts 2:14), so Max became the de facto leader of the leadership team. His first achievement was to give a group of dedicated, loyal, but nevertheless disaffected young people a chance to prove their worth. Then, he helped guide them from discontentment with the status quo to pro-active engagement in church life.

Sixth, the group was made up of individuals who were certain of divine leadership. They prayed for and reckoned with the intervention of the Holy Spirit. Their prayers were not mere formalities but earnest pleas for his leading. In this they emulated the example of Jesus and also that of the SDA pioneers who invested large portions of their time in prayer, discussion, fasting, and Bible searching.

Seventh, without being chosen for their complementary aptitudes the individuals of the group showed a wide range of leadership gifts. Nor were they afraid of inviting others of an older generation onto the team who brought different gifts to the group. In 
this respect too, the group followed the counsel of Ellen White when she reminded workers that they should not "call together a certain chosen number who think as you do, and who will say Amen to all that you propose, while others are excluded, who you think will not be in harmony."1

Eighth, each of the members of the team showed maturity of character. All of the Team members were reliable in their accomplishment of tasks, and willing to do what was promised.

Ninth, there was willingness on the part of established leadership to allow the members of the Geroma to exert an influence on the church. Rather than reacting defensively they provided an example of empowering leadership. Further, in the course of time, established church leadership was able to take advantage of the sense of urgency which the Team created. The church board in effect rode the wave of renewal for which the Team was originally responsible.

I am convinced that the Oerlikon Strategic Leadership Team was a gift from God, and am both grateful, and humbled for his goodness in giving us such a fine body of people, at a time when our church so desperately needed renewal.

${ }^{1}$ White, Life Sketches, 321. 


\section{CHAPTER 6}

\section{STRATEGIC PLANNING, ACHIEVEMENTS, AND INITIAL EVALUATION OF THE STRATEGIC LEADERSHIP TEAM}

\section{Strategic Planning and Achievements}

Chapter 5 described the formation and dynamics of the Strategic Leadership Team of the Oerlikon SDA Church. It also described the vision around which the Team united. This chapter will first describe how the Team went on to form and implement its strategy. Then it will analyze the successes and mistakes of the Team by comparing them with the theory described in chapter 4 .

\section{Planning Objectives and Forming Strategy}

In order to promote their vision of church growth and personal sanctification the Team adopted a strategy of promoting small groups. They quickly adopted a long term objective: the Team aimed to integrate 80 percent of the church into small groups within five years.

In order to reach that objective they first started by writing down the names of those church members they thought would be willing to become small group leaders. These names were divided up between the individual members of the Team. Each Team member took on the task of challenging the people on his list to become small group leaders and encouraging them to think about who they could invite to their small groups. 
Next, the Team organized a training seminar for small group leaders. The Geroma decided to contact one of the Adventist ministers in the Zuerich area who is known for his small group emphasis and to ask him to conduct a series of five training units designed to help small group leaders set up and lead small groups.

Finally, before going ahead with the plan the Team took a further decision. They decided to organize regular meetings for small group leaders. Reading had shown that one of the primary causes for the failure of small groups was lack of support for group leaders. The Team asked the church pastor to set up a monthly meeting for small group leaders to overcome this hurdle. The Team did not develop a further strategy at this point but decided to start implementing their decisions.

One of the remarkable aspects of this strategic planning was that it was developed with little delay. The Team only once engaged in a brainstorming session in order to develop its plans. Most of the time, the group rapidly came up with practical suggestions which were equally quickly adopted. This rapidity of decision owed a lot to the experience and the visionary nature of its de facto leader, Max.

\section{Implementing the Small Group Strategy and Developing the Strategic Plan}

Once the pastor agreed to conduct a training seminar for small group leaders the members of the Strategic Leadership Team contacted the church members who they considered to be potential group leaders and invited them to the training program. The result was that the first training program was attended by approximately a dozen people who were either interested in joining a small group or who were interested in leading small groups. As a result five small groups came into existence in the fall of 2006 
involving approximately twenty-five to thirty members of the church. In addition, there were approximately sixteen non-Adventists in the groups.

Simultaneously, the church pastor set up support meetings for group leaders. The original aim was to hold them once a month. This proved impossible as a result of time constraints. Eventually they were held about eight times a year. These meetings proved to be popular with small group leaders. Their popularity lay in the fact that they provided a platform for small group leaders to openly discuss their challenges and find solutions for their problems among themselves.

This was a time of great excitement for the members of the Strategic Leadership Team. They not only saw results for their efforts but their aim of reaching out to nonAdventists was also being fulfilled. Team meetings were held almost on a monthly basis. They were characterized by celebration as well as serious discussion about the way to go forward.

\section{Communicating the Strategy}

The initial success energized the members of the Strategic Leadership Team in their communication of their strategy. First, a number of church services were organized in which the biblical basis for small groups was described or in which members of a small group led the service. Then the Team came up with the idea of organizing a small group church outing. The whole church was invited to come and bring friends. The outing provided an opportunity for sightseeing. As part of the trip the tour bus stopped at a picturesque Adventist Church which is located in the Alpine foothills. There the Team conducted worship and talked about the advantages of small groups. As well as helping 
promote the small group concept within the church, this outing also introduced some of the non-Adventist invited friends to the concept. The finances for this outing were provided by a generous donor and did not affect the church budget at all.

As a further means of promoting the project a short "brush-up" course for small group leaders was organized one evening in the autumn of 2007. This course dealt with the seven common mistakes of group leaders. Its aim was to help keep existing group leaders on track. But as an additional benefit a number of potential small group leaders who were also invited received an introduction into small group leadership. As part of the course a simple evening meal was offered.

\section{Building on the Strategy}

By the fall of 2007 every church member was aware of the small group emphasis in the church. The Team had not only communicated its strategy well but the involvement of nearly a quarter of the church members in the project had meant that it was being talked about a lot in the church. In the fall of 2007 the Strategic Leadership Team reviewed its accomplishments and agreed on a new goal. It aimed to set up seven new small groups in 2008. It also decided to repeat the pattern of training and brush-up program in the coming year so that new small-group leaders could be invited and existing small-group leaders could be trained and motivated. A new date was set for a small group leader training course in 2008. Once again potential small group leaders were invited.

In addition, the Team was also able to secure the services of Russell Burrill who came to Switzerland in August 2008. A regional day of fellowship was organized in which Russell Burrill motivated church members to set up evangelistic small groups. 
Using the materials out of his book Recovering an Adventist Approach to the Life and Mission of the Local Church he not only explained the biblical nature of small groups but also showed how important they were for Adventist pioneers. The aim of this day of fellowship was not just to motivate but also to create a sense of urgency for the strategy.

\section{Promotion of Other Ministry Teams}

In addition to promoting small groups the Strategic Leadership Team recognized that there were a number of areas of church life which needed attention. As a result of reading Courageous Leadership by Bill Hybels the Team decided to promote the "WordShare-Prayer" structure at every meeting of every ministry group within the church. This was an attempt at transferring the basic principle of small groups to ministry teams.

Two ministry groups which needed attention were the greeters and those operating the PA system. Both groups were encouraged to meet regularly for prayer, the training of team members, and evaluation. The new initiatives provided a much-needed boost to both groups. New members were added to both teams. The quality of service which both teams provided for the church was also improved.

After initial enthusiasm, however, the challenges of the initiatives became evident. It was hard to get members of the teams to sacrifice their time to meet regularly. Although both teams did their job well it was almost impossible to get teams together on a regular basis for prayer, evaluation, and sharing. Unfortunately the Strategic Leadership Team did not follow through with this initiative and both the team of greeters and the team operating the PA system fell back into their old habits. 
Introduction of Testimonies into the Church Service

A further important initiative came when the leadership team recognized the necessity of adding the element of community to the church service. A number of team members read the book James White: Innovator and Overcomer, written by Gerald Wheeler. ${ }^{1}$ They realized that early Adventist meetings were characterized by testimonies. The leadership team became instrumental in introducing a time for testimony into the church service. Members and visitors were given time at the start of the preaching hour to testify as to what God has done for them. This resulted in some remarkable testimonies and engendered a sense of community within the church. This initiative of the Strategic Leadership Team remains popular.

\section{Summary}

When focusing on its core strategy, that of promoting holistic small groups, the Team did well. As a result of its common vision the group quickly adopted a sensible strategy and agreed on clear objectives. Within a year more than a quarter of the approximately hundred-member church was involved in small groups.

In branching out into attempting to reform ministry teams, however, the Team attempted to accomplish more than its members were able to consistently monitor. Their efforts were not wasted but due to lack of time and energy to sustain the reforms they were not lasting.

'Gerald Wheeler, James White: Innovator and Overcomer (Hagerstown, MD: Review and Herald, 2003). 


\section{An Initial Evaluation}

While the previous sections in this chapter have dealt with the achievements which the Team realized in its strategy for the Church, this section will concentrate on the attainments the Team made in organizing itself. Some things the Team got right. Others it needed to do differently. These will be assessed with a view to making recommendations for the future in the final chapter. The reason this appraisal can only be called an initial evaluation is because two years is too short to evaluate a strategy which aimed at changing the culture of a church.

\section{Reasons for Successes}

\section{Successful Planning}

The Team made a lot of good decisions. Once the initial founders of the Team had overcome their doubts as to whether they should attempt to revive the church, their work at the planning stage was exemplary. Convinced of the beliefs and the mission of the church, and keen to see their local church grow, the Team put a lot of effort into forming a strategy. They spent hours reading and discussing various books which were designed to help them in this process. Assimilating advice from books on leadership and church growth was one of the reasons the Team got a lot of things right. Books by Russell Burrill and Bill Hybels were a genuine help in deciding in which direction to move as well as being effective motivators in the process of strategic planning.

\section{Accountability}

The Team spent much time with each other and as individuals praying, reflecting, and planning their strategy. As the Team then implemented the strategy each member 
accepted responsibility for different aspects of the plan. The members of the group were very conscientious in fulfilling their tasks. The group developed a high level of accountability. Their effectiveness in both planning and implementation resulted in a number of short-term wins. More than one long-term church member was surprised by the amount of people who joined small groups.

\section{The Team Leader}

Perhaps the most important single reasons for the success of the Team was the presence of Max, whose incisive leadership coupled with a tactful personal style, was responsible for leading the Team to wise decisions and logical planning steps. Max helped the Team establish a sense of urgency by suggesting the invitation of Russell Burrill, for example. He also helped generate short-term wins by fostering the rapid introduction of small groups.

\section{Mistakes}

\section{Weakness in Long-term Follow-through}

It is by its long-term results that the project will eventually be measured, and it is the long term implementation which presented the Team with its greatest challenges. It has already been noted that the Team workers were stretched for time. Lack of time added to the difficulties as the Team lost some of its impetus in 2008. At the beginning of the project roughly 25 percent of the church was involved in small groups. The Team aimed to double this number in 2008. This did not happen, however. In 2008 the number of church members in small groups remained roughly the same as in 2007. The Team 
needed to discuss ways of establishing a sense of urgency among church members in order to push the project forward. Instead the group tended to avoid the issue.

\section{Integration of Future Leaders}

A further lack was the integration of new members into the Team. Once the Team took shape in 2007 it remained static as far as its members were concerned. There was no attempt to plan for new or replacement members. In all fairness it must be noted that this was not intentional but rather a result of the age structure of the church: there is a fairly large age gap between the young people involved in the Team and those both below them and above them in age. Nevertheless by the summer of 2008 it became evident that the Team was in need of fresh ideas and new blood.

\section{Recognition of Accomplishment}

Finally the Team needed to find a way of recognizing accomplishment. All the Team members put an enormous effort into their work. Some sacrificed financially as well. Sometimes this effort was acknowledged, as when individual team members sent thank you e-mails to their co-workers for their time and effort. But much work was done with minimal expression of appreciation. Publicly staged expressions of gratitude are not a part of Swiss culture and this was an area in which sensitivity needed to be used. Nevertheless, the achievements of the Team were not acknowledged as they should have been. It is possible that the slow-down in team work in 2008 was partly the result of too little appreciation of the contribution which the members of the Team made. 


\section{Evaluation}

Probably the biggest mistake which the Team made was not to cement regular evaluations of the team's work into team meetings. While team members discussed their opinion of certain events after they had taken place, there was little attempt to discover the point of view of the intended recipients. The Team was content, for example, with the fact that a church outing aimed at promoting small groups went well at the organizational level, but never stopped to ask how effectively it increased the number of participants in small groups.

Further, having achieved a number of short-term wins it failed to take time to evaluate its achievements. Evaluation at this point would have made a number of problems evident. Problem number one lay in the fact that the number of church members involved in small groups peaked out at the beginning of 2008. A second problem was that one or two members of the Team were obviously suffering from work overload. On more than one occasion they missed team meetings. An honest appraisal of this situation would almost certainly have been the first step toward finding solutions for these problems. Instead of taking time for evaluation, however, the Team avoided the issues.

\section{Consolidating Gains}

In 2008 there was little growth in the small group project. Particularly evident was the difficulty in keeping small groups evangelistic. The groups experienced little growth. This was not the point for the Team to become complacent. On the contrary the Team 
needed to build on its gains and find creative ways of pushing forward. However, too little thought was given to this need.

\section{Particular Challenges}

\section{Mobility}

In addition to listing successes and mistakes it is useful to mention particular challenges which the Team faced. One of the challenges which the Strategic Leadership Team faced was the mobility of the young people within it. Almost all of the original Team members were students or involved in further study in some way. Of the original six who first started to talk and pray about the need to revive our church two moved to different locations early on in the life of the Team. Although one of these two will return from further training after a year this mobility has had the effect of reducing the creativity of the Team and of placing a greater burden of responsibility on those who remain.

\section{Time}

A further difficulty was the time challenge. All of the members of the Team had multiple responsibilities in the church even before they started working as a leadership team. One of the young people was Sabbath school teacher, music worship leader, and small group leader as well as being a member of the Strategic Leadership Team. Finding time to balance work, family, and church commitments became difficult.

\section{Discouragement and Persistence}

Finally, after two years or so of effort, enthusiasm on the Team began to wane in 2008. There were a number of causes for this. One was certainly the lack of apparent 
progress despite the enormous amount of energy expended by the Team in promoting small groups. It became clear that a large section of the church did not want to respond to the small group emphasis. This apparent apathy was felt to be discouraging.

Another drain on enthusiasm was the realization that it was harder to keep the process of change going than it was to initiate it. Initial successes in implementing the plan led the Team to believe that achieving the goal of integrating 80 percent of the church into evangelistically-oriented small groups would be accomplished relatively quickly. As this turned out not to be the case the group became discouraged. Anchoring change into the church culture was harder than first thought. At this stage the Team showed signs of internal discord. While some wanted to start new initiatives others recognized the necessity of consolidating the gains which had been achieved. This discord surprised the Team which had always worked in perfect harmony up until this point.

\section{Summary}

The challenges which the Team faced are common to most leadership teams. With time, enthusiasm wanes. As the successes peak out teams tend to lose their determination to press towards their goals. Other priorities tend to replace those of the Team. Despite the high commitment of the Team the challenges of maintaining impetus resulted in a tendency to avoid difficult decisions, and even in a certain amount of discord. As 2008 draws to a close there is a strong feeling among the core members of the Team that it is important to write and sign a group covenant for 2009 in order for the Team to remain effective. 


\section{CHAPTER 7}

\section{CONCLUSIONS AND RECOMMENDATIONS}

\section{Introduction}

This final assessment will compare the results of the Team with its stated aims. It will then both draw conclusions concerning the work of the Team during the past three years 2006-2008, and make recommendations for the work of the Team in the future. It is hoped that other Strategic Leadership Teams will find the exercise to be of benefit.

\section{A Comparison of Aims and Results}

The Strategic Leadership Team of the Oerlikon SDA Church did not turn the church around within the three years under discussion. According to the membership statistics for the years 2006-2008 the Oerlikon Church continued to stagnate. But the Team did begin to achieve part of its vision. Its aim of leading people to Jesus through the medium of small groups was fulfilled in one case. One person who was a member of a small group was baptized within this period. Yet despite the fact that the introduction of small groups into church life did not change the church's negative growth pattern it did show promise. As of October 2008 twenty non-Adventists were taking part in small groups, many of whom were moving towards baptism. This represented an approximate 300 percent increase in the number of contacts involved in Bible study in comparison with 2004-2005. 
Further, the Team was instrumental in encouraging a missionary mentality within a section of the church. Its vision was to involve 80 percent of the church membership in evangelistic small groups. To date it has succeeded in involving approximately 30 percent of the church in such groups. While this is only a partial success it nevertheless represents a major achievement in a church which has seen little change in thirty years. The challenge is to extend this partial success.

Despite the fact that the Team would have liked to have achieved more it can nevertheless be grateful for a further major victory. Its existence has shown that it is possible to successfully set up a Strategic Leadership Team within existing SDA church structures and to start implementing the change process without causing bitter power struggles or being divisive of church unity. The challenge of change is to introduce the new while allowing the old to be replaced gracefully. The Strategic Leadership Team, in starting down the road to deep change, is accomplishing this task. This is a major achievement, a gift of God, and the result of the prayers of many concerned church members.

What conclusions can be drawn from the exercise?

\section{Conclusions}

Leadership Teams Are a Divine Construct

Although the theological examination of inspired counsel on leadership in this paper was by no means exhaustive there is sufficient biblical evidence to show that shared leadership is not a human but a divine construct. The life of Moses makes the case for team leadership. Moses was brought up under a leadership system which emphasized 
individualism but when called by God to lead Israel he involved others in the leadership of that nation. This he did, not as a result of his own volition but because God instructed him to draw others into the leadership process. Similarly, the New Testament doctrine of spiritual gifts teaches the interdependence which lies at the heart of team leadership.

Although team leadership is nowhere commanded, both the New Testament and the Old Testament illustrate and teach its principles, thus confirming its divine origin.

The Emergence of the Team Was Not as Spontaneous as Appeared at First Glance

In some churches Strategic Leadership Teams will have to be created by the senior pastor or a skillful lay leader. This was not the case in the Oerlikon SDA Church. The Team appeared to emerge spontaneously. This spontaneity was not, however, as surprising or unexpected as may appear at first glance. All of the young people involved had been highly active in the youth work of the church. As a result of holding responsibility for youth programs, including church services and evangelistic meetings they had already gained experience in leadership.

Further, many of the dynamics present within the Team had been developed during the time in which the young people had worked in youth ministry. For example, while working in youth leadership, they spent time in fellowship and worship, by eating, praying, and discussing God's Word together. This formed the basis of their team work once they became responsible for the strategic planning of the church as a whole. Thus the emergence of spontaneous leadership teams was not as spontaneous as may appear at first glance, but was the result of the experience developed while previously working for a department of the church. 


\section{The Team Was Productive Because Its Servant-Leaders}

Had Different Aptitudes

In the past, leadership structures have often been made up of strong leaders surrounded by a competent staff of helpers. The conflict caused when strong leaders attempted to work together has fed the myth that strong leaders work best alone ("too many cooks spoil the broth"). But the divine pattern of leadership calls for servantleaders with different capabilities ("aptitudes") to band together into teams. There were found to be at least three of the four leadership aptitudes described by George Barna on the Leadership Team of the Oerlikon SDA Church: the directing leader, the teambuilding leader, and the strategic leader. ${ }^{1}$ Operational leadership was latent within the group. Had it been more overtly present it may have been responsible for avoiding some of the classic traps which the group fell into, such as the failure to evaluate its performance.

The Team Was Able to Provide Leadership Because It Was Accepted by the Church Body

Once the Team emerged, tension was felt on the church board. The church board, quite reasonably, wished to know what the aims and values of the Team were. However, due to the willingness on the part of both the existing leadership and on the part of the church as a whole to accept the new Team, it was able to start the process of renewal within the church.

${ }^{1}$ George Barna, A Fish Out of Water (Nashville, TN: Integrity Publishers, 2002), 43-50. 
Working on the Leadership Team Required Effort, Persistence, and Skill

It took a great deal of effort for the Team to start the change process in a longestablished and stagnating church. It took even more effort and above-average persistence to keep the change process going. Finally, anchoring the change process into the culture of the church will take constant effort, relentless persistence, and much skill.

The difficulty of the task was seen in the effects of the Strategic Leadership Team on the mission of the Oerlikon SDA Church. Within the time frame of the three years covered by this paper the Team was at best able to include 30 percent of church members in small groups. Its aim of integrating 80 percent of the church into small groups within five years looks unrealistic at the present point in time. Further, the aim of using the small groups evangelistically in order to further church growth did not meet with a great deal of initial success. The small group emphasis meant that the baptismal decision of one person was encouraged and supported within that two year period, but did not result in as many baptisms as hoped. None of these changes can be considered huge successes. They underline the complexity of the task and the need for persistence.

The Team Accomplished Far More Than an Individual Could Have Done Within the Same Time Frame

Despite the complexity of the task and the frustration which accompanied disappointed expectations, the Team accomplished far more than an individual could have done within the same time frame. This fact confirms that the divine pattern of leadership is corporate rather than based on gifted individuals. 


\section{Work on the Team Was Satisfying and Provided}

Experience for the Future

The complexity of the task should not discourage other pastors and leaders from attempting the process of working with Strategic Leadership Teams. On the contrary, despite the frustrations which the Team experienced, the challenge of leadership teams was found to be highly satisfying. Despite setbacks, work on the Team provided experience for the leaders involved. Just what the results of the experience gained will be in the future cannot be measured. However, all of the leaders involved in the Team gained a sense of fulfillment from their awareness of serving God and following in the footsteps of Jesus.

\section{Evaluation Must be Honest and Consistent}

Possibly the biggest error which the Team made was not to cement regular evaluations of the Team's work into team meetings. Its particular mistake was not to discover the effect of the programs or initiatives on the intended recipients, whose point of view was rarely sought.

This was probably due to the number of short-term wins and successes which the Team chalked up within the first year or so of its activity. Regular evaluations would have made a number of long-term problems evident and would have helped avoid the stagnation which the Team experienced at the beginning of 2008. A consistent and honest appraisal of every initiative would almost certainly have been the first step toward finding solutions for the problems which later arose. 


\section{The Team Failed to Look For and Develop New Leaders}

A further lapse which the Team committed was to fall into what Bill Hybels calls the "trap of urgent demands." The Team expended its energy in completing the tasks which it felt to be most urgent. It did not pause long enough to wonder about future leaders. To be fair, the question of future leaders is not one which usually will exercise most teams within the first two or three years of their lives. However, as it becomes apparent that the vision of the Team will not be achieved in the short-term, and that certain members of the Team are becoming fatigued, the question of leadership redundancy and of the need for future leaders needs to be addressed.

\section{Integrating a Strategic Leadership Team into Existing SDA Church Structures Represents a Major Victory}

A major success was the integration of the Team into existing leadership structures in the Oerlikon Church. It was able to start the process of change without causing power struggles or splitting the church. Although the Team has only been able to initiate the change process and has by no means completed its task, the fact that it has become an accepted entity must be considered a major victory.

\section{Recommendations}

The following recommendations are specifically related to the Strategic Leadership Team of the Oerlikon SDA Church. They are included because most will also apply to Strategic Leadership Teams in general.

\footnotetext{
${ }^{2}$ Hybels, 123.
} 


\section{The Team Leader Must Model Persistence in the Face of Discouragement}

Enthusiasm will always wane. The reasons can be various: lack of apparent progress despite the energy expended; lack of time and the need to balance other commitments with the demands of Team work; the realization that the task involved will not be accomplished quickly; internal discord, and finally, the inertia of human nature which finds comfort more convenient than persistent effort. For this reason it is important for the team leader to make team members aware of the need for persistence. This must be done both by modeling persistency and encouraging members to stay the course.

\section{Sign a Covenant and Reconfirm the Vision Regularly}

As noted above, work on a leadership team requires a great deal of persistence. For this reason a key recommendation is to write and sign a group covenant. Although signing a covenant will not guarantee perseverance it does reinforce the members' commitment. The Team leader needs to prepare a simple covenant for the year ahead which will include a commitment to attending Team meetings regularly.

In addition, it is vital to repeat the vision. Church members are not paid to be part of a leadership team; it is the vision which motivates them. For this reason it is important for the Team leader to repeat the vision in order to reconfirm the commitment of the group to its principles.

Find a Way of Relieving the Work Load of Existing Leaders

George Barna quite rightly states that burn-out among leaders occurs when good leaders are overused. He then suggests that leaders should not be allowed to lead more 
than one team: "Limit your leaders to one team at a time,", he writes. All of the Leaders on the Strategic Leadership Team also lead other groups within the Church. This is a symptom of the classic twenty to eighty syndrome in which 20 percent of the church does 80 percent of the work. The Team needs to start 2008 by finding a way of relieving the work load of existing leaders and delegating work to others.

\section{Look for Emerging Leaders and Mentor Them}

With time, every team member becomes redundant. In addition, most visions will only be realized in the long-term. As a result the identification and eventual integration of new leaders onto the Team is necessary in order for the vision to be accomplished. There needs to be time, energy, and money (training courses, for example) invested in these future leaders. In the words of Christian Schwarz, emerging leaders need to be "empowered." The Team needs both to identify future leaders and assign a member (or members) of the Team to mentoring them. This can be accomplished in various relatively simple ways: taking them out for a meal and asking them about their needs or challenges; attempting to provide support for those needs by identifying resources; praying for them; maintaining contact, and giving them responsibility.

Find a Way of Evaluating the Progress of the Vision

Evaluation of individual strategic initiatives can be done relatively simply. A short questionnaire can be developed and completed by participants in order to evaluate

${ }^{3}$ Barna, The Power of Team Leadership, 179.

${ }^{4}$ Christian Schwarz, Natuerliche Gemeindeentwicklung [Natural Church Development] (Rothrist, Schweiz: Koinonia Verlag, 1966), 22. 
events which the Team organizes (such as a training course for future small group leaders, for example). In addition, the Team needs to continue to set quantitative goals and measure its progress against these goals. Such goals should include the number of small groups, the number of church members taking part in small groups, and the number of non-members involved in those groups. The Team needs to delegate evaluation to one of its members.

Finally, the Team needs to find a way of evaluating the "soft" goals of its vision, which are far more difficult to quantify. In its vision the Team recognized that the structure of small groups is a vehicle for spiritual growth. The vision statement of the Team read: "We want our church to lead people to Jesus. We want to help people to grow in faith, in love towards God, and their fellow human beings." The Team needs to evaluate if spiritual growth is occurring, as evidenced by an increase in faith and love towards God and fellow human beings. Only then, can the Team be sure that its small group emphasis is producing desirable results. The Team needs to find a simple means of evaluating its progress in this area. This could take the form of a simple questionnaire which asks "before" and "after" questions. One such question could be: "What words would you use to describe your commitment to Christ before your involvement with your small group, and what words would you use to describe your commitment to Christ after being involved with your small group for a year?"

\section{Communicate Regularly with the Church Body}

John Kotter suggests that change managers undercommunicate. ${ }^{5}$ The Team needs

\footnotetext{
${ }^{5}$ Kotter, 85.
} 
to take the opportunity of communicating its plans and ideas at church business meetings. These meetings are held twice a year in the Oerlikon SDA Church. The advantage of communication at church business meetings is that there is chance for discussion with the church body. Thus the Team will be able to hear the responses of the church to its initiatives and will be better able to tailor its strategy to the church's way of thinking.

The Next Steps Which the Team Needs to Take

The partial accomplishment of the vision is a reason for gratitude and celebration on the part of the Team. However, the Team needs to accept the challenge of the next step. The basic challenge is to get the church to own the vision of small groups. In order to find acceptance of this vision the Team needs to win both the hearts and the minds of a majority of the church congregation. The Team needs to think creatively about how to do this, recognizing that it will be much harder to win over the next $25-30$ percent of the church than it was to reach the first. This milestone needs to be reached within the next one to two years.

\section{The Basic Principles of Team Leadership Need to be Taught}

Church leaders need to be aware of the basic principles of team leadership. These principles should not necessarily be taught at the seminary level where they will probably remain theoretical but should be integrated into the training of interns in the first years of pastoral internship. Senior pastors must include ministerial interns in their leadership teams and give them responsibility. They need to learn by doing. 


\section{Final Conclusion}

The experience of the Strategic Leadership Team in the Oerlikon Church shows that one of the pitfalls of strategic leadership is to underestimate the challenges which the process of change requires within a declining organization. Despite being blessed with faithful, enthusiastic, and skillful team members the Team was only able to start the change process among a large minority of church members within the three years under scrutiny in this paper. Anchoring change within the organization will require further effort coupled with a great deal of persistence over the next decade.

On the other hand, the work of the Team must be compared with what would probably have occurred had it not come into existence. Because of its existence, evangelistic efforts have been coordinated and focused. A large minority of the church has been encouraged to think evangelistically and a number of non-Adventists are involved in Bible study. For this we thank God. Sola Dei Gloria. 


\section{APPENDIX 1}

\section{CREATING A CLIMATE FAVORABLE TO STRATEGIC LEADERSHIP TEAMS}

The vision of a Strategic Leadership Team can mean change for many people and will often initially be met with a great deal of skepticism. In order for new ideas to be accepted the leader of the Strategic Leadership Team may well have to create a church climate which is receptive to change.

An ideal time for a new pastor to set up a Strategic Leadership Team is within the first two years of his arrival. The first year or so will be spent in getting to know key leaders and gaining the trust of the church. Once the pastor has begun to assess the qualities of his co-workers then the process of recruitment can begin. Usually, however, the mere advent of a new leader is not sufficient to create the climate necessary for change to occur.

Prayer is the key to change. God answers prayer, particularly when his people pray together. If there are no prayer groups within the church they need to be strongly encouraged. The church, and particularly the prayer groups of the church, must be encouraged to pray that God will bless and guide the outreach of the church.

A sense of urgency needs to be created. The current situation of the church needs to be analyzed. Membership statistics, the aging pattern of the church, attendance statistics and giving patterns need to be examined in order to show the health of the church. If the statistics show negative trends or even stagnation then a sense of urgency can be communicated quite legitimately. In addition, the life cycle of churches can be 
discussed with the church leadership in order to show how the church can be expected to develop within the next few years. A useful aid to this exercise can be found in chapter three of Waking the Dead by Russell Burrill. ${ }^{1}$ Many church boards have read this book chapter by chapter as preparation for their monthly board meeting. Very often the Holy Spirit uses such literature to create a sense of the need for action among dedicated leadership.

A further step in creating a climate for change is to foster the desire for something better. This can be accomplished by recounting successful stories of outreach, or by telling stories of how other churches have succeeded. Positive examples of success engender enthusiasm for trying new ideas.

Finally, the church can be invited to a Sabbath afternoon of brainstorming for mission. The tools which can be used are described in chapter 4 section 2 of this paper. Storyboarding techniques are particularly useful for assessing the willingness of the average member for change. If well-organized, the ideas exchanged can generate enthusiasm for outreach.

Essential to change is trust. The character of the leader of change must be trustworthy in order for people to accept the vision. If this is not the case then the resistance to change will produce conflict which can be highly destructive of the church. 41.

${ }^{1}$ Russell C. Burrill, Waking the Dead (Hagerstown, MD: Review and Herald, 2004), 31- 


\title{
APPENDIX 2
}

\section{PERSONALITY STYLES AT A GLANCE}

\author{
Active Roles \\ D Style
}

Dominant, determined, driver. Likes to take on active roles and is task-oriented.

Main features: good problem solver, risk taker, strong ego, self-starter, goal-oriented.

Value to the group: good motivator, good at organizing events, values time, resultsoriented. Danger zones: argumentative, does not like routine, oversteps authority at times, ca be pushy. Greatest fear: being taken advantage of.

\section{Style}

Influencing, inspiring, impulsive. Likes to take on active roles and is peopleoriented. Main features: outgoing, talkative, enthusiastic, persuasive, optimistic, trusting, emotional. Value to the group: good encourager, good sense of humor, peacemaker, creative problem solver. Danger zones: Inattentive to detail, prefers popularity to tangible results, "convenient" listener, may be disorganized. Greatest fear: rejection, loss of social approval.

\section{Passive Roles}

C Style

Compliant, cautious, correct. Likes to take on passive roles and is task-oriented. Main features: thinks things through, accurate, high standards, careful, systematic, precise. Value to group: good organizer, follows directions, even-tempered, clarifies 
situation well. Danger zones: finds fault easily, focused on details and may miss the big picture, too critical at times. Greatest fear: criticism of work and efforts.

\section{S style}

Steady, supportive, stable. Likes to take on passive roles and is people-oriented.

Main features: warm, friendly, understanding, patient, easygoing, good follow-through.

Value to group: good listener, team player, loyal, reliable, dependable, patient \& empathetic. Danger zones: resistant to change, "holds it" inside, difficulty prioritizing, overly sensitive. Greatest fear: loss of security and stability. ${ }^{1}$

${ }^{1}$ IML DISC, The Keys for Positive Relationships (New Castle, PA: The Institute for Motivational Living, Inc., 1998-2003), 11. 


\begin{abstract}
APPENDIX 3
CHURCH MEMBERSHIP STATISTICS OERLIKON SDA CHURCH 1968-2004
\end{abstract}

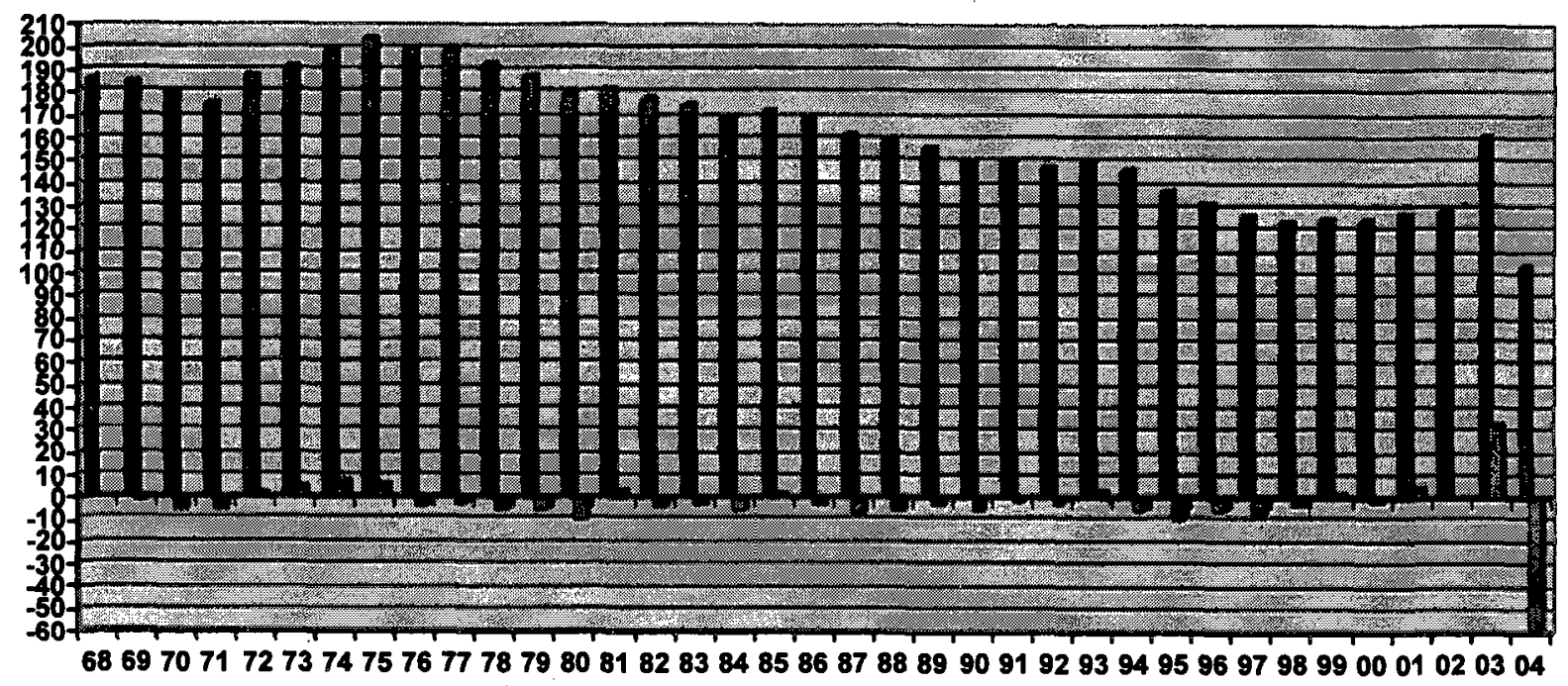

The Oerlikon SDA Church was originally formed as a church plant in 1948. At that time it numbered 55 members. It reached a peak of 204 members in 1975. Then it declined numerically virtually every year until 2004 when it totaled 104 members. This represented a membership loss of nearly 50 percent in thirty years. The one exception to this decline occurred between the years 1999 and 2003 when an influx of Hispanic members caused the church to grow. At the beginning of 2004 the Hispanic group was formed into a separate local church. With their departure in 2004 the church reverted to its original composition of German-speaking members. The decline can be clearly seen. 


\section{APPENDIX 4}

\section{AGE STRUCTURE SDA OERLIKON CHUR̈CH JUNE 2004}

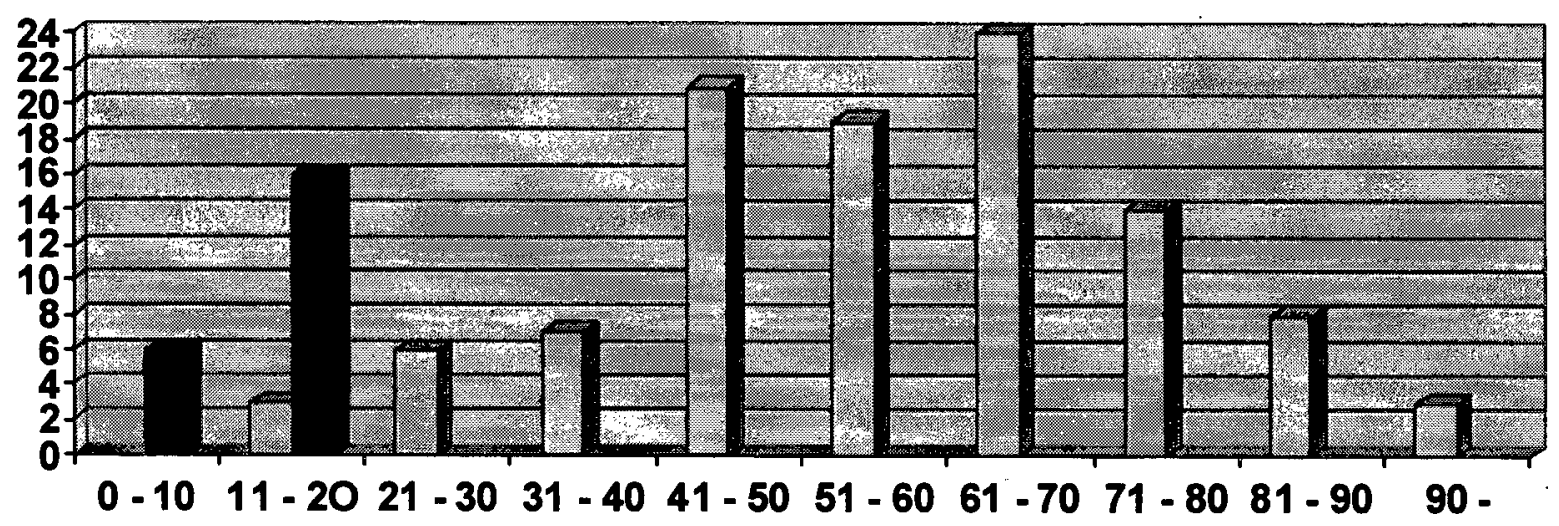

$\square$ baptized members $\square$ unbaptized children and young people

In June 2004 nearly 50 percent of the members in the Oerlikon SDA Church were over the age of sixty. 


\section{BIBLIOGRAPHY}

Antoine de Saint-Exupery Quotes. http://www.brainyquote.com/quotes/authors/a/ antoine_de_saintexupery.html (accessed 17 June 2008).

Bandy, Thomas G. Kicking Habits: Welcome Relief for Addicted Churches. Nashville, TN: Abingdon Press, 2001.

Barclay, William. The Gospel of John. Vol. 2. Edinburgh, Scotland: The Saint Andrew Press, 1956.

Barna, George. A Fish Out of Water. Brentwood, TN: Integrity Publishers, 2002.

. The Power of Team Leadership: Achieving Success through Shared

Responsibility. Colorado Springs, CO: Waterbrook Press, 2001.

. The Power of Vision. Ventura, CA: Regal Books, 2003.

. The Second Coming of the Church. Nashville, TN: Word Pub., 1998.

. Turnaround Churches. Ventura, CA: Regal Books, 1993.

Batchelor, Doug. The Last Elijah Message: Essentials for Revival. Roseville, CA: Amazing Facts, 2002.

Beckham, William A. The Second Reformation: Reshaping the Church for the TwentyFirst Century. Houston, TX: Touch Publications, 1995.

Bell, Skip. A Time to Serve: Church Leadership for the 21st Century. Lincoln, NE: Advent Source, 2003.

Bosch, David J. Transforming Mission. Maryknoll, NY: Orbis Books, 1991.

Boshers, Bo. Small Group Resources. Grand Rapids, MI: Zondervan, 1997.

Burns, Robert. Selected Poems: To a Mouse. Ware, Hertfordshire, England: Wordsworth Edition Limited, 1994.

Burrill, Russell C. Recovering an Adventist Approach to the Life and Mission of the Local Church. Fallbrook, CA: Hart Research Center, 1996. 
. Revolution in the Church. Fallbrook, CA: Hart Research Center, 1993.

. Waking the Dead. Hagerstown, MD: Review and Herald, 2004.

Calian, Carnegie Samuel. Survival or Revival: Ten Keys to Church Vitality. Louisville, KY: Westminster John Knox Press, 1998.

Callahan, Kennon L. Effective Church Leadership. New York: Harper \& Row, 1990.

Christliches Zentrum Buchegg. http://www.czb.ch/wer sind wir/geschichte/ (accessed 24 October 2008).

Cladis, George. Leading the Team-Based Church: How Pastors and Church Staffs Can Grow Together into a Powerful Fellowship of Leaders. San Francisco, CA: Jossey-Bass, 1999.

Cole, Neil. Cultivating a Life for God. St. Charles, IL: ChurchSmart Recources, 1999.

Conn, Harvie M., ed. Planting and Growing Urban Churches. Grand Rapids, MI: Baker Books, 1997.

Conner, Mark. “A NT Pattern of Church Leadership." Internet Essay, September 2001, 8, http://jmm.aaa.net.au/articles/9305.htm (accessed 29 December 2007).

Cordeiro, Wayne. Doing Church as a Team. Ventura, CA: Regal Books, 2001.

Crandall, Ronald K. Turnaround Strategies for the Small Church. Nashville, TN: Abingdon Press, 1995.

Dayton, Edward R., and David A. Fraser. Planning Strategies for World Evangelization. Grand Rapids, MI: W. B. Eerdmans, 1990.

"DISC assessment." Wikipedia. http://en.wikipedia.org/wiki/DISC_assessment (accessed 11 March 2008).

Domanyi, Thomas. Du hast uns - Herr - gerufen. Zürich, ZH: Carta Druck AG, 1987.

Donahue, Bill, and Russ Robinson. Walking the Small Group Tightrope: Meeting the Challenges Every Small Group Faces. Grand Rapids, MI: Zondervan, 2003.

Easum, William M. Sacred Cows Make Gourmet Burgers. Nashville, TN: Abingdon Press, 1995.

Gangel, Kenneth O. Coaching Ministry Teams: Leadership and Management in Christian Organizations. Nashville, TN: Word Pub., 2000. 
Giles, Kevin. Patterns of Ministry among the First Christians. Melbourne, Australia: Collins Dove, 1989.

Gladden, Ron. The 7 Habits of Highly Ineffective Churches. Vancouver, WA: Adventist Church Planting Center, 2003.

Haggard, Ted. Dog Training, Fly Fishing, and Sharing Christ in the 21st Century: Empowering Your Church to Build Community through Shared Interests. Nashville, TN: Nelson Books, 2002.

Hahne, Peter. Schluss mit Lustig! Das Ende der Spassgesellschaft. Lahr/Schwarzwald: Verlag der St.-Johannis-Druckerei, 2004.

Holthaus, Stephan. Trends 2000: Der Zeitgeist und die Christen. Basel: Brunnen-Verlag, 1998.

Hunter, George G. How to Reach Secular People. Nashville, TN: Abingdon Press, 1992.

Hunter, Kent R. The Jesus Enterprise: Engaging Culture to Reach the Unchurched. Nashville, TN: Abingdon Press, 2004.

Hybels, Bill. Courageous Leadership. Grand Rapids, MI: Zondervan, 2002.

Icenogle, Gareth Weldon. Biblical Foundations for Small Group Ministry. Downers Grove, IL: InterVarsity Press, 1994.

IML DISC. The Keys for Positive Relationships. New Castle, PA: The Institute for Motivational Living, 1998-2003.

Knight, George R. The Fat Lady and the Kingdom: Confronting the Challenge of Change and Secularization. Boise, ID: Pacific Press, 1995.

Kotter, John P. Leading Change. Boston, MA: Harvard Business School Press, 1996.

Kouzes, James M., and Barry Z. Posner. The Leadership Challenge. San Francisco, CA: Jossey-Bass, 2002. 2004.

. Reflections on the Leadership Challenge. San Francisco, CA: Jossey Bass,

Kysar, Robert. Stumbling in the Light: New Testament Images for a Changing Church. St. Louis, MO: Chalice Press, 1999.

Lawless, Charles E. Discipled Warriors: Growing Healthy Churches That Are Equipped for Spiritual Warfare. Grand Rapids, MI: Kregel Publications, 2002. 
Lencioni, Patrick. The Five Dysfunctions of a Team: A Leadership Fable. San Francisco CA: Jossey-Bass, 2002.

. The Four Obsessions of an Extraordinary Executive: A Leadership Fable. San Francisco, CA: Jossey-Bass, 2000.

Lingenfelter, Sherwood G., and Marvin K. Mayers. Ministering Cross-Culturally. Grand Rapids, MI: Baker Academic, 2003.

Linthicum, Robert C. Transforming Power: Biblical Strategies for Making a Difference in Your Community. Downers Grove, IL: InterVarsity Press, 2003.

Logan, Robert E., and Sherilyn Carlton. Coaching 101: Discover the Power of Coaching. St. Charles, IL: ChurchSmart Resources, 2003.

Long, Jimmy. Generating Hope. Downers Grove, IL: InterVarsity Press, 1997.

Lundblad, Barbara K. Transforming the Stone: Preaching through Resistance to Change. Nashville, TN: Abingdon Press, 2001.

Maddux, Robert B. Team Building. London: Kogan Page, 1998.

Malphurs, Aubrey. Advanced Strategic Planning. Grand Rapids, MI: Baker Books, 2005. . Planting Growing Churches. Grand Rapids, MI: Baker Books, 1998.

Mann, Alice. The In-Between Church: Navigating Size Transitions in Congregations. Bethesda, MD: Alban Institute Press, 1998.

Martin, Glen, and Gary McIntosh. The Issachar Factor. Nashville, TN: Broadman \& Holman, 1993.

Maxson, Ben. "Geistliche Leiterschaft." Paper presented at the Spiritual Leadership Seminar, Kaprun, Austria, 17-24 September 2001.

Maxwell, Randy. Bring Back the Glory: What Happens When God's People Pray for Revival. Nampa, ID: Pacific Press, 2000.

McIntosh, Gary. Staff Your Church for Growth: Building Team Ministry in the 21st Century. Grand Rapids, MI: Baker Books, 2000.

Minatrea, Milfred. Shaped by God's Heart: The Passion and Practices of Missional Churches. San Francisco, CA: Jossey-Bass, 2004.

Mittelberg, Mark. Building a Contagious Church. Grand Rapids, MI: Zondervan, 2001.

Monroe, Kelly. Finding God at Harvard. Grand Rapids, MI: Zondervan, 1997. 
Mundey, Paul. Unlocking Church Doors: Ten Keys to Positive Change. Nashville, TN: Abingdon Press, 1997.

Nelson, Alan, and Gene Appel. How to Change Your Church (Without Killing It). Nashville, TN: W Publishing Group, 2000.

Nunes, Fausto Edgar."Introducing Adventist Distinctives in New Fields: A Literary and Historical Analysis of Selected Counsels by Ellen G. White." Research Proposal, Andrews University, August 2004.

Ortiz, Manuel, and Susan S. Baker, eds. The Urban Face of Mission: Ministering the Gospel in a Diverse and Changing World. Phillipsburg, NY: P\&R Pub., 2002.

Ott, E. Stanley. Transform Your Church with Ministry Teams. Grand Rapids, MI: Eerdmans, 2004.

Pocock, Michael, and Joseph Henriques. Cultural Change and Your Church: Helping Your Church Thrive in a Diverse Society. Grand Rapids, MI: Baker Books, 2002.

Quinn, Robert E. Deep Change: Discovering the Leader Within. San Francisco, CA: Jossey-Bass, 1996.

Rainer, Thom S. Breakout Churches. Grand Rapids, MI: Zondervan, 2005. . Surprising Insights from the Unchurched and Proven Ways to Reach Them. Grand Rapids, MI: Zondervan, 2001.

Rendle, Gilbert R. Leading Change in the Congregation: Spiritual and Organizational Tools for Leaders. Bethesda, MD: Alban Institute, 1998.

Robinson, Anthony B. Transforming Congregational Culture. Grand Rapids, MI: Eerdmans, 2003.

Sahlin, Monte. Adventist Congregations Today. Lincoln, NE: Center for Creative Ministry, 2003.

."What Makes Churches Grow? What Recent Adventist Research Reveals." Ministry 76 (November 2004): 5-11.

Schaller, Lyle E. Discontinuity and Hope: Radical Change and the Path to the Future. Nashville, TN: Abingdon Press, 1999.

Schmidt, Eduard. "Intervention for Renewal." Class notes for Formation of Evangelistic Strategy, Andrews University, Summer 2006.

Schwarz, Christian. Die Natürliche Gemeindeentwicklung. Rothrist: Koinonia Verlag, 1996. 
. Natural Church Development. Carol Stream, IL: ChurchSmart Resources, 1996.

Senge, Peter M. The Fifth Discipline: The Art and Practice of the Learning Organization. New York: Doubleday, 1990.

Seventh-day Adventist Bible Dictionary. Edited by Siegfried H. Horn. Washington, DC: Review and Herald, 1960. S.v. "Elder."

Shelley, Marshall, ed. Empowering Your Church through Creativity and Change: 30 Strategies to Transform Your Ministry. Nashville, TN: Moorings, 1995.

Southerland, Dan. Transitioning: Leading Your Church through Change. Grand Rapids, MI: Zondervan, 2000.

Southern, Richard, and Robert Norton. Cracking Your Congregation's Code. San Francisco, CA: Jossey-Bass, 2001.

Statistisches Amt des Kantons Zurich. Statistisches Jahrbuch des Kantons Zurich 2005. Zurich: Statistisches Amt des Kantons Zurich, 2004.

Strobel, Lee. Inside the Mind of Unchurched Harry and Mary. Grand Rapids, MI: Zondervan, 1993.

Strommen, Merton P. The Innovative Church: Seven Steps to Positive Change in Your Congregation. Minneapolis, MN: Augsburg, 1997.

Sweet, Leonard. Aqua Church. Loveland, CO: Group Pub., 1999.

Trent, John. Leading from Your Strengths. Nashville, TN: Broadman \& Holman, 1999.

Tutsch, Cynthia Ann. "Ellen White's Counsel to Leaders: Identification and Synthesis of Principles, Experiential Application, and Comparison with Current Leadership Literature." D.Min. dissertation, Andrews University, 2006.

Venden, Lee. It's All About Him. Hagerstown, MD: Review and Herald, 2004.

Wagner, Peter C. Strategies for Church Growth. Ventura, CA: Regal Books, 1987.

Weick, Karl E. Making Sense of the Organization. Malden, MA: Blackwell Pub., 2001.

Westing, Harold J. Church Staff Handbook: How to Build an Effective Ministry Team. Grand Rapids, MI: Kregel Publications, 1997.

Wheeler, Gerald. James White: Innovator and Overcomer. Hagerstown, MD: Review and Herald, 2003. 
White, Ellen G. Christian Experience and Teachings. Mountain View, CA: Pacific Press, 1922.

. Christian Service. Washington, DC: Ellen G. White Estate, 1996.

. Counsels on Diets and Foods. Washington,DC: Review and Herald, 1938.

. The Desire of Ages. Mountain View, CA: Pacific Press, 1940.

. Education. Mountain View, CA: Pacific Press, 1952.

. Evangelism. Washington,DC: Review and Herald, 1970.

. Lessons from the Life of Nehemiah. Washington, DC: Ellen White Estate, n.d.

. Life Sketches. Mountain View, CA: Pacific Press, 1943.

. Ministry of Healing. Mountain View, CA: Pacific Press, 1942.

. Testimonies for the Church. Vol. 3. Mountain View, CA: Pacific Press, 1948.

White, James Emery. Rethinking the Church: A Challenge to Creative Redesign in an Age of Transition. Grand Rapids, MI: Baker Books, 2003.

Wood, Gene. Leading Turnaround Churches. St. Charles, IL: ChurchSmart Resources, 2001.

Wood, Gene, and Daniel Harkavy. Leading Turnaround Teams. St. Charles, IL:

ChurchSmart Resources, 2001. 


\section{VITA}

Name

Date of birth

Paul Norman Thomas Wright

Nationality

May 24, 1955

British and Swiss citizen

Place of birth

Civil status

Languages

Ordination to

Newcastle-under-Lyme, GB

Married to Mirjam Wright-Fontana

German: fluent spoken and written

English: mother tongue

March 10, 1990

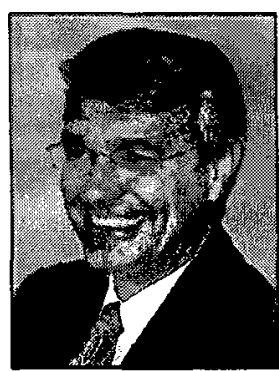

Gospel ministry

\section{EDUCATION \& TRAINING}

2004- D.Min., Andrews University, USA

2003

Further education credits in training pastoral interns

1993-1994

Swiss business diploma in banking

1985

Das kleine Deutsche Sprachdiplom (German language diploma)

Goethe Institute, Austria

1983

$1979-1980$

M.Div. (Summa cum Laude), Andrews University, USA

1974-1979

Higher Diploma in Theology Newbold College, GB

Higher Diploma in Theology, Newbold College, $G B$

\section{PROFESSIONAL HISTORY}

2004- Swiss German Conference of SDA, Switzerland. Pastor and evangelist in Oerlikon and Wetzikon.

1995-2004 Swiss German Conference of SDA, Switzerland. Pastor and evangelist, including training a ministerial intern in Lucerne, Baar and Brunnen

1993-1994 Basellandschaftliche Kantonalbank, Switzerland. Trainee in banking.

1992 Franz Fontana, Zementwaren, Reigoldswil. Full-time employee.

1987-1991 Swiss German Conference of SDA, Switzerland. Pastor in Oerlikon (under a senior pastor) and Wetzikon.

1984-1987. Seminar Schloss Bogenhofen (Theological Seminary), Austria. Preceptor of men's dormitory and teacher of NT and practical theology.

1981-1982 SDA South England Conference. Pastor and evangelist in Gloucester (Internship), Brighton and Worthing.

1976 Nile Union Secondary School, Cairo (Egypt). Assistant English language teacher. 